2. To: (Receiving organization)

Solid watie lianagent.

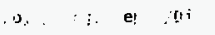

Solid Waste Displas

d. Clis dt Remelks:

Attached is the Central Waste Complex FHA for review and approval.

11. Rer : iver Remarks:

\begin{tabular}{|l|r}
\hline 3. From: Coriginating organization) & 4. Related EDT No.: \\
Solid Waste Management & N/A \\
\hline 6. cog. Engr.: & 7. Purchase Order No.: \\
R.M. Irwin & W402442
\end{tabular}

9. Equip./Component No.:

$$
\mathrm{N} / \mathrm{A}
$$

10. System/Bldg./Facility:

Central Waste Complex

12. Major Assm. DWJ. No.:

N/A

15. Fermit/Permit Application No.: $N / A$

14. Required Response Date: $4 / 12 / 96$

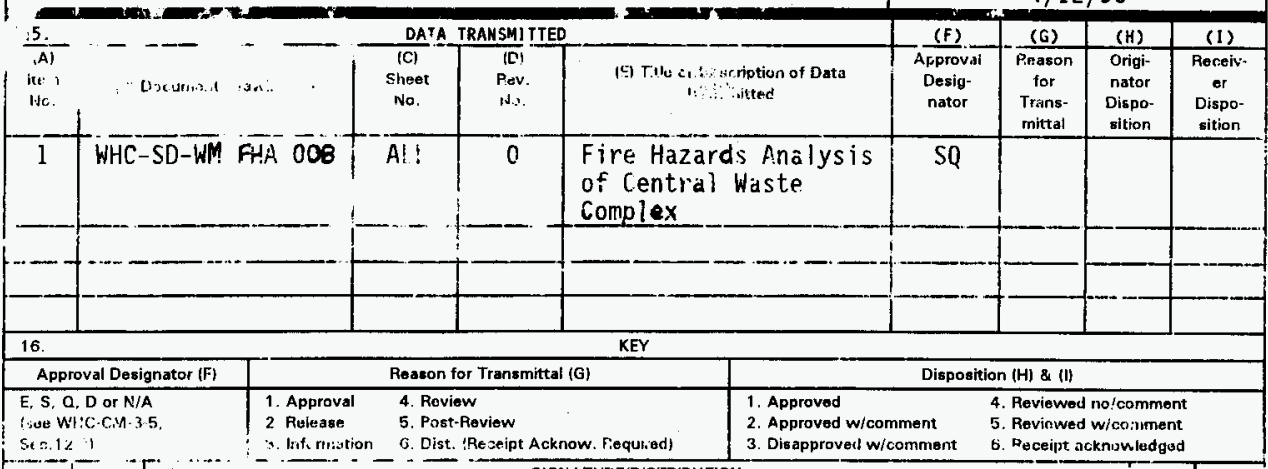

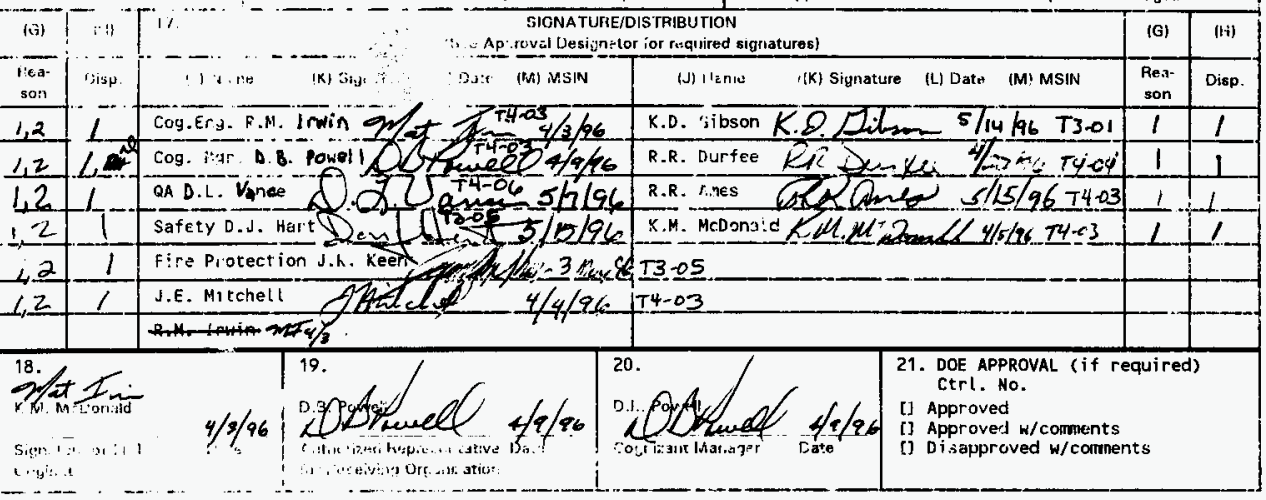

Bi-74r, - 1: : : $6: / s:, 19 \%$

Nangy 


\title{
Fire Hazards Analysis of Central Waste Complex
}

\author{
RM Irwin \\ Westinghouse Hanford Company, Richland, WA 99352 \\ U.S. Department of Energy Contract DE-AC06-87RL 10930 \\ EDT/ECN: 603184 \\ Org Ccde: 87250 \\ UC: 510 \\ B\&R Code: Ew3130020 \\ Charge Code: A4V10 \\ Total Pages: 107106 dp $5 / 30 / 96$
}

Key Words: CWC, SWM, FHA

Abstract: This document analyzes the fire hazards associated with operations at the Central Waste Complex. It provides the analys is and recommendations necessary to ensure compliance with applicable fire codes.

TRADEMARK DISCLAIMER. Reference herein to any specific comercial product, process, or service by trade name, trademark, manufacturer, or otherwise, does not necessarily constitute or imply its endorsenent, recommendation, or favoring by the United States Goverment or any agency thereof or its contractors or subcontractors.

Printed in the United States of America. To obtain copies of this document, contact: WHC/BCS Ducument Control Services, P.O. BOX 1970, Mailstop H6-08, Richland HA 99352, Phone (509) 372-2420; Fax (509) 376-4989.
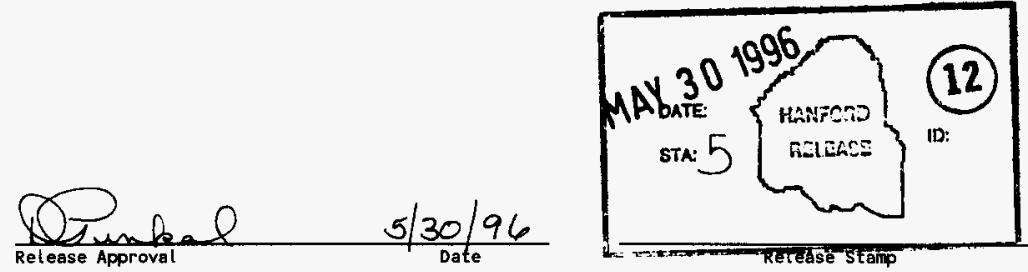

\section{Approved for Public Release}




\author{
FIRE HAZARDS ANALYSIS \\ FOR \\ CENTRAL WASTE COMPLEX \\ BUIDINGS 2401 W, $2402 \mathrm{~W}$ - WL, \\ 2403 WA, WB, WC, AND WD, \\ LFMW AND AMW MODULES, AND \\ MIXED WASTE STORAGE PAD \\ WESTINGHOUSE HANFORD COMTANY \\ RICHLAND, WA
}

\author{
Prepared by: \\ HSB Professional Loss Control
}

Revision: 0

Submitted: February 23, 1996

Prepared by:

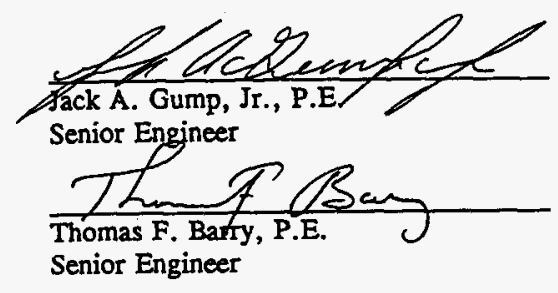

Reviewed by:

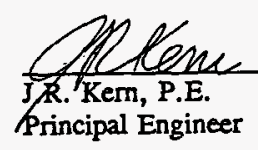


WHC-SD-WM-FHA-008, Rev. 0

Page 2

This page intentionally left blank 


\section{TABLE OF CONTENTS}

Subject

Page

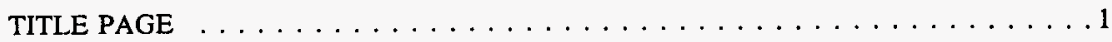

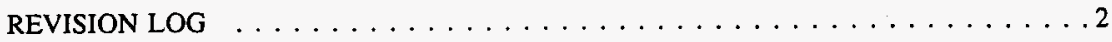

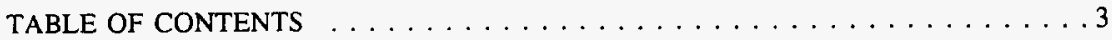

1.0 FACILITY DESCRIPTION AND LOCATION $\ldots \ldots \ldots \ldots \ldots \ldots \ldots \ldots$

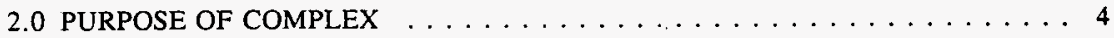

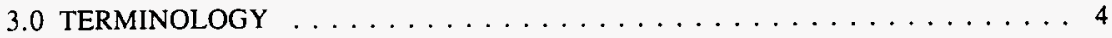

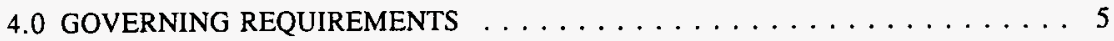

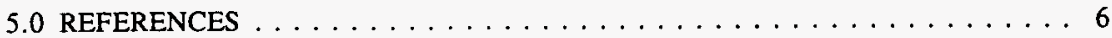

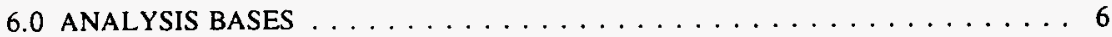

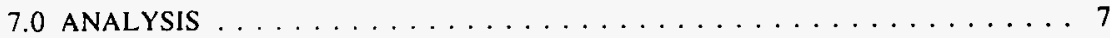

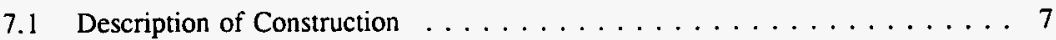

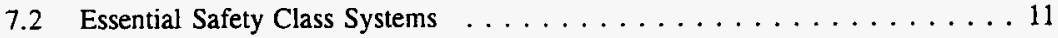

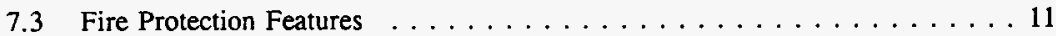

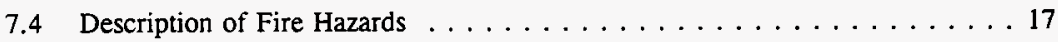

7.5 Life Safety Considerations . . . . . . . . . . . . . . 19

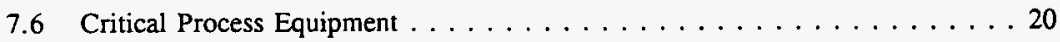

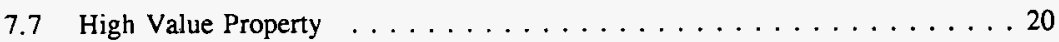

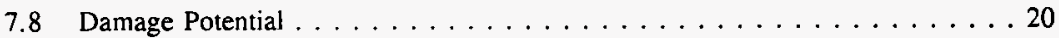

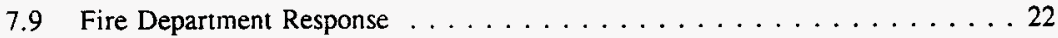

7.10 Recovery Potential . . . . . . . . . . . . . . . 26

7.11 Potential for a Toxic, Biological, and/or Radiation Incident Due to a Fire . . 27

7.12 Emergency Planning . . . . . . . . . . . . . . . . . 27

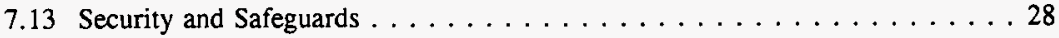

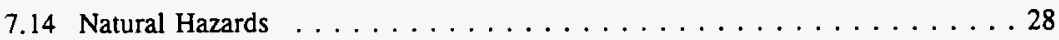

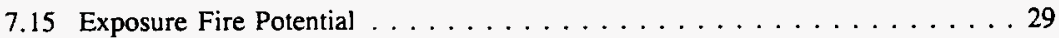

7.16 National Security Consequences . . . . . . . . . . . . . . . . . . 29

8.0 CONCLUSION . . . . . . . . . . . . . . . . . . . . . . . 29

9.0 RECOMMENDATIONS AND SUGGESTED IMPROVEMENTS . . . . . . . 30 APPENDIX A.....SITE LAYOUT DRAWINGS

APPENDIX B.....CENTRAL WASTE COMPLEX FIRE RISK ASSESSMENT APPENDIX C.....ESTIMATION OF GROUND CONTAMINATION FROM FIRE APPENDIX D.....SWM SUPPORTING INFORMATION FOR CWC FHA 


\subsection{FACILITY DESCRIPTION AND LOCATION}

The Hanford Site covers approximately 1,450 square $\mathrm{km}$ (560 square miles) of semiarid land owned by the U.S. Government and managed by the Department of Energy (DOE) near Richland, Washington. The Central Waste Complex is located in the 200 West area of the DOE Hanford Site. The Central Waste Complex was constructed in the 1980's and early 1990's for the storage of Polychlorinated Biphenyl (PCB) and mixed hazardous wastes contaminated with various radioactive isotopes. The portion of the Central Waste Complex where materials are stored (facilities within the fenced area) consists of the Radioactive and Mixed Waste Storage Facilities (Buildings 2401W, 2402-W through WL, and 2403-WA, WB, WC, and WD), nineteen Low Flash Point Mixed Waste Storage Modules (LFMW), four Alkali Metal Waste Storage Modules (AMW), the Mixed Waste Storage Pad, and the Waste Unloading and Storage Pad. Additional support buildings, mostly consisting of office-type occupancies, are located on the south side of the Central Waste Complex.

Refer to area and site drawings in Appendix A of this report.

\subsection{PURPOSE OF COMPLEX}

The Central Waste Complex (CWC) provides storage space for mixed wastes [to comply with requirements of the Resource Conservation and Recovery Act (RCRA) of 1976 (EPA 1981)] as well as contact-handled radioactive waste before final disposition. Operations conducted at the CWC complex include waste receipt, storage, certification, and offsite shipment.

Refer to drawings provided in Appendix A of this report.

\subsection{TERMINOLOGY}

a. Automatic Fire Suppression - Sharply reducing the heat release rate of a fire and preventing its regrowth by means of direct and sufficient application of sprinkler system water spray through the fire plume to the burning fuel surface.

b. Fire Control - Limiting the size of a fire by distribution of water so as to decrease the heat release rate and to pre-wet adjacent combustibles, while controlling ceiling gas temperatures and avoiding structural damage until the fuel can be eliminated or extinguishing can be effected.

c. Partial Fire Control - Limiting the size of a fire by distribution of water so as to limit the increase in the heat release rate and to pre-wet adjacent combustibles, while controlling the increase in ceiling gas temperatures and delaying structural damage. 
d. Ineffective Manual Fire Fighting Response - Manual fire fighting response times and fire fighting tactics which are not sufficient to prevent major or total building failure or significant releases of a hazardous material.

e. Effective Manual Fire Fighting Response - Manual fire fighting response times and fire fighting tactics which are sufficient to prevent building failure or significant releases of a hazardous material.

f. Uncontrolled Fire Incident - A fire that grows and propagates due to ineffective automatic and manual fire suppression operations and storage configuration.

\title{
4.0 GOVERNING REOUIREMENTS
}

The following specific regulations, codes, and standards were utilized as reference or background material for the preparation of this fire hazards analysis.

Occupational Safety and Health Administration (OSHA)

29 CFR, 1910 - SUBPART E - MEANS OF EGRESS (September 12, 1980)

29 CFR, 1910 - SUBPART L - FIRE PROTECTION (September 12, 1980)

Department of Energy (DOE) Orders

DOE 5480.4 ENVIRONMENTAL PROTECTION, SAFETY, AND HEALTH PROTECTION STANDARDS $(5 / 15 / 84)$

DOE 5480.7A FIRE PROTECTION (2/17/93)

DOE 6430.1A GENERAL DESIGN CRITERIA (4/6/89)

\author{
National Fire Protection Association (NFPA) \\ NFPA 10 PORTABLE FIRE EXTINGUISHERS (1994) \\ NFPA 13 INSTALLATION OF SPRINKLER SYSTEMS (1994) \\ NFPA 24 INSTALLATION OF PRIVATE FIRE SERVICE MAINS AND THEIR \\ APPURTENANCES (1992) \\ NFPA 25 INSPECTION, TESTING, AND MAINTENANCE OF WATER-BASED \\ FIRE PROTECTION SYSTEMS (1992) \\ NFPA 72 NATIONAL FIRE ALARM CODE (1993) \\ NFPA 80 FIRE DOORS AND WINDOWS (1992) \\ NFPA 80A PROTECTION OF BUILDINGS FROM EXPOSURE FIRES (1993) \\ NFPA 101 LIFE SAFETY CODE (1994) \\ NFPA 231 GENERAL STORAGE (1990) \\ NFPA 505 POWERED INDUSTRIAL TRUCKS (1992) \\ UL Directories (1994) \\ EM Approval Guide (1994) \\ Uniform Building Code (1991) \\ Uniform Fire Code (1991)
}




\subsection{REFERENCES}

a) Central Waste Complex Interim Safery Basis, Westinghouse Hanford Company, Rev. 0, draft dated May, 1995.

b) Summary of Research and Development Activities in Support of Waste Acceptance Criteria for WIPP, SAND79-1305, Sandia Laboratories, dated June 1979.

c) Fire Testing of 55 Gallon Metal Waste Drums for Dry Waste Storage, HK Hasegawa, KJ Staggs, SM Doughty, Lawrence Livermore National Laboratory, dated July 1993.

d) Fire Protection Handbook, National Fire Protection Association, Seventeenth Edition.

e) Fire Protection Program Manual, WHC-CM-4-41, Westinghouse Hanford Company, August 17, 1992.

f) Building Emergency Plan for the Central Waste Complex, Westinghouse Hanford Company, WHC-IP-0263-CWC, dated August 31, 1993.

g) FAX, Supplemental Informarion for CWC FHA, From Kent McDonald To Jack Gump, dated 10/07/94.

h) Fire Protection Program Manual, Warer Supplies, WHC-CM-4-41, dated August 17, 1992.

i) Fire Alarm Receiving System Hanford Fire Department write-up, Hanford Fire Department.

j) Pyrotronics and GH Harlow manufacturer data sheets.

k) Central Waste Complex Final Safery Analysis Report, Final Safery Analysis Document Upgrade, WHC-SD-WM-SAR-049, Westinghouse Hanford Company, dated May, 1995.

1) Hazard Identification and Accident Scenario Development for the Central Waste Complex (CWC), Draft.

m) Fire Protection Through Modern Building Codes, American Iron and Steel Institute, Fourth Edition, Part I, Chapter 12.

n) The SFPE Handbook of Fire Protection Engineering, Society of Fire Protection Engineers and National Fire Protection Association, Section 3, Chapter 7, Table 37.1 and Figure 3-7.1.

o) "Solid Waste Drum Array Fire Performance," WHC-SD-WM-TRP-246, Hughes Associates, Inc., Rev. 0, dated November, 1995.

\subsection{ANALYSIS BASES}

1. Information provided in the Central Waste Complex Interim Safety Basis is accurate.

2. Information on drawings provided by Westinghouse Hanford Company representatives is accurate.

3. Information obtained during interviews and telephone conversations with Westinghouse Hanford Company site representatives is accurate.

4. No plastic pallets are in use in the CWC. 
5. Polyethylene overpacks are subsequently packed in noncombustible containers.

6. Drums are banded (except those in partial pallet loads directly on the floor).

\subsection{ANALYSIS}

\subsection{Description of Construction}

Buildings $2401 \mathrm{~W}, 2402 \mathrm{~W}$ through WL, and $2403 \mathrm{WA}, \mathrm{WB}, \mathrm{WC}$, and WD consist of pre-engineered steel structures. Buildings $2401 \mathrm{~W}$ and $2402 \mathrm{~W}$ through WL are 24.4 $\mathrm{m}$ (80 ft.) long and $15.2 \mathrm{~m}$ (50 ft.) wide with a minimum clear span of $13.7 \mathrm{~m} \mathrm{(45}$ $\mathrm{ft}$.) and an eave height of $6.1 \mathrm{~m}(20 \mathrm{ft}$.). These structures are covered with 26-gauge sheet metal to form the exterior walls and roof. Each structure has two 2.1-m (7-ft.) by $0.9-\mathrm{m}$ (3-ft.) pedestrian doors. Building $2401 \mathrm{~W}$ has one and Buildings $2402 \mathrm{~W}$ through WL each have two $4.8-\mathrm{m}$ (16-ft.) high by $3.7-\mathrm{m}(12-\mathrm{ft}$.) wide metal roll-up door(s). The foundation is integrated into a perimeter concrete curb $1.8 \mathrm{~m}(6 \mathrm{in}$.) above grade. The facility floor is level and at grade. Building $2401 \mathrm{~W}$ and Building 2402 through WL are designed to meet the requirements for PCB, hazardous, radioactive, and mixed waste storage (Section 5.0, reference "k"). Each building can accommodate approximately one thousand 208-L (55-gal.) drums.

Buildings 2403 WA, WB, and WC are $61 \mathrm{~m}$ (200 ft.) long and 51.8 (170 ft.) wide with an eave height of $6.1 \mathrm{~m}$ (20 ft.). There are fourteen interior, unprotected-steel columns supporting the roof structure (two columns supporting each rigid frame member). These structures are covered with 24-gauge sheet metal to form the exterior walls and roof. Each structure has four $2.1-\mathrm{m}(7-\mathrm{ft}$.) by $0.9-\mathrm{m}$ (3-ft.) pedestrian doors and two $5.5-\mathrm{m}$ (18-ft.) high by $6.3-\mathrm{m}$ (12-ft.) wide metal roll-up door(s). Each building is divided into four quadrants. The floor of each quadrant slopes toward a 0.6-m wide $\times 0.6-\mathrm{m}$ long $\times 0.5-\mathrm{m}$ deep $(2-\mathrm{ft} . \times 2-\mathrm{ft} . \times 1.5 \mathrm{ft}$.) sump in the center of each quadrant. It is reported (Section 5.0, reference " $k$ ") that these buildings are designed to meet the requirements for hazardous, mixed, and radioactive waste storage (Section 5.0, reference "k"). Each building can accommodate approximately twelve thousand 208-L (55-gal.) drums.

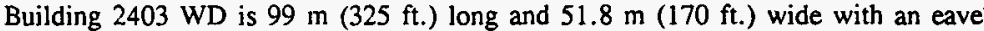
height of $6.1 \mathrm{~m}(20-\mathrm{ft}$.). There are twenty-four interior, unprotected-steel, columns supporting the roof structure (two columns supporting each rigid frame member). The exterior walls and roof are covered with 24-gauge sheet metal. The structure has six 2.1-m (7-ft.) by $0.9-m$ (3-ft.) pedestrian doors and two 5.5-m (18-ft.) high by $6.3-\mathrm{m}$ (12-ft.) wide metal roll-up door(s). The building is divided into four quadrants. The floor of each quadrant slopes toward a $0.6-\mathrm{m}$ wide $\times 0.6-\mathrm{m}$ long $\times 0.5-\mathrm{m}$ deep (2-ft. $\times 2-\mathrm{ft}$. $\times 1.5 \mathrm{ft}$.) sump in the center of each quadrant. This building (Section 5.0, reference " $k "$ ) meets the requirements for hazardous, mixed, and radio- 
active waste storage. The building (Section 5.0, reference " $k "$ ) can accommodate approximately nineteen thousand $208-\mathrm{L}$ (55-gal.) drums.

Nineteen LFMW Modules are located on an asphalt pad at the southwest corner of the CWC fenced storage area. These modules are designed to meet the requirements for hazardous and radioactive waste storage [except flammable Transuranic (TRU) waste storage (Section 5.0, reference "k"). Two modules (Modules 20 and 21) have been modified for TRU flammable waste storage. The modules consist of portable, premanufactured metal structures. Several different types (manufacturers) and sizes of modules are provided. Some of the modules have a fire resistant material sandwiched between metal panels to form fire barriers. There was no LFMW Moduie construction data available during the survey, and an attempt to contact manufacturers provided limited information. The sizes of the modules range from $4.3 \mathrm{~m}$ long $\times 2.4$ $\mathrm{m}$ wide $\times 2.4 \mathrm{~m}$ high ( $14 \mathrm{ft} . \times 8 \mathrm{ft} . \times 8 \mathrm{ft}$.) to $9.8 \mathrm{~m}$ long $\times 2.4 \mathrm{~m}$ wide $\times 2.6 \mathrm{~m}$ high ( $32 \mathrm{ft} . \times 8 \mathrm{ft} . \times 8.5 \mathrm{ft}$.). Some manufacturers indicated that the walls and ceilings of the modules are rated for a 2-hour fire duration and other manufacturers indicated that their modules are not fire rated. Each module has a minimum $10 \mathrm{~cm}(4 \mathrm{in}$.) deep catch sump under the storage floor. The floors over the sump are made of wood, fiberglass, or metal with openings (grating) to permit liquid drainage to the sump. LFMW Modules 20 and 21 (reference Appendix A, Drawing FHA-CWC-S) have been provided with ventilation and electrical service. Electrical service within these two modules is approved for Class I, Division 1, Groups C and D. General hazard-type electrical equipment is provided for the continuous air monitors (CAMs)

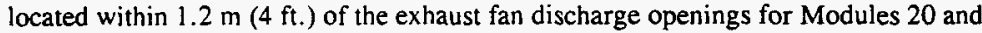
21. Each module is anchored and grounded. The largest LFMW Modules (LFMW Modules 3 and 11) can each accommodate approximately thirty-three 208-L (55-gal.) drums (eleven drums per compartment). The total capacity within all LFMW Modules is approximately three hundred and sixty 208-L (55-gal.) drums. Storage consists of flammable Low Level Waste (LLW), Low-Level Mixed Wastes (LL-MW), Transuranic (TRU), and Transuranic Mixed Waste (TRU-MW) with flash-points below $37.8^{\circ} \mathrm{C}\left(100^{\circ} \mathrm{F}\right)$. (Reference Appendix D for SWM Supporing Information)

Four AMW Modules are also provided at the southwest pad. These modules are designed to meet the requirements for low-level radioactive alkali metal mixed-waste storage (Section 5.0, reference "k"). The AMW Storage Modules are also portable, premanufactured metal structures. The exterior walls and roof do not provide a fire barrier, based on the absence of sandwiched wall panels. There was no AMW Module construction data or manufacturer information available during the survey. The modules are $7.3 \mathrm{~m}$ long $\times 2.7 \mathrm{~m}$ wide $\times 2.7 \mathrm{~m}$ high $(24 \mathrm{ft}$. $\times 9 \mathrm{ft} . \times 8.75 \mathrm{ft}$.). The floors are constructed of open metal grating over a $1.8 \mathrm{~m}(6 \mathrm{in}$.) deep catch sump. Each module is anchored and grounded.

Fire modeling indicates that a fire inside one module should not result in fire propagation to an adjacent module. Fire modeling is based on minimum spacing of 15 feet 
between modules. The AMW Modules (LFMW Modules 18, 19, 22, and 23) can each accommodate approximately twenty-four 208-L (55-gal.) drums.

The Waste Unloading and Storage (WUS) pad is an asphalt pad approximately $61 \mathrm{~m}$ (200 ft.) long by $46 \mathrm{~m}$ (150 ft.) wide. The pad is used for handling and staging containers of radioactive contaminated waste destined for the various storage buildings and modules. A dock is provided for unloading and loading shipments. There are no curbs or berms around the WUS pad. It is reported (Section 5.0, reference " $k$ ") that the WUS pad does not meet RCRA requirements for compliant MW storage.

The Mixed Waste Storage Pad is a concrete pad approximately $30.1 \mathrm{~m}$ (99 ft.) long and 24.4 ( $80 \mathrm{ft}$.) wide. The pad is used for short term storage until material can be moved to the storage buildings or modules. The pad slopes toward the east and west to a culvert that extends the length of the pad. The culvert slopes toward the north where a valve is provided to release rainwater after being checked for contamination.

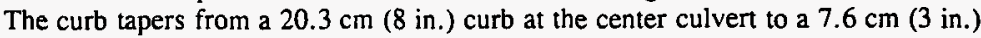
curb at the edge of the east and west sides.

Water is provided to Buildings $2401 \mathrm{~W}, 2402 \mathrm{~W}$ through WL, and $2403 \mathrm{WA}, \mathrm{WB}$, WC, and WD for fire suppression by a $25.4 \mathrm{~cm}$ (10 in.) diameter potable water main loop. Sprinkler system lead-ins are provided by $20.3 \mathrm{~cm}$ (8 in.) diameter pipes for Building $2403 \mathrm{WD}, 15.2 \mathrm{~cm}$ (6 in.) diameter pipes for Buildings $2403 \mathrm{WA}$, WB, and $\mathrm{WC}$, and $10.2 \mathrm{~cm}$ (4 in.) diameter pipe for Buildings $2401 \mathrm{~W}$ and $2402 \mathrm{~W}$ through WL. Double check valve assemblies are provided for the portion of the water supply loop feeding the sprinkler systems. There is no water supply to the LFMW and AMW Modules.

Electrical service is provided to Buildings $2401 \mathrm{~W}, 2402 \mathrm{~W}$ through WL, $2403 \mathrm{WA}$, WB, WC, and WD, and Modules 20 and 21 . There are no redundant power supplies or emergency backup power supplies to these CWC structures.

Forced mechanical ventilation is provided for Buildings $2401 \mathrm{~W}, 2402 \mathrm{~W}$ through WL, 2403 WA, WB, WC, and WD, and Modules 20 and 21. Ventilation for Buildings $2401 \mathrm{~W}$ and $2402 \mathrm{~W}$ through $\mathrm{WL}$ is provided by two exhaust fans and two makeup air vents for each building. The fans are reported to be rated for 3,000 CFM each and have metal backdraft louvers. Each makeup air vent consist of a lou-

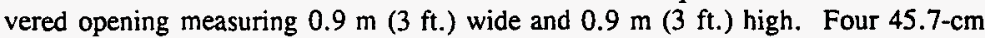
(18-in.) by $45.7-\mathrm{cm}$ (18-in.) fiberglass filters with cardboard frames are provided over the interior side of each makeup air vent. The metal louvers for the makeup air vents are fixed in place.

Ventilation for Buildings 2403 WA, WB, and WC is provided by four exhaust fans and eight makeup air vents for each building. The fans are reported to be rated for 13,340 CFM each and have metal backdraft louvers. Fan openings are each approxi- 
mately $1.1 \mathrm{~m} \mathrm{(} 3.75 \mathrm{ft}$.$) by 1.1 \mathrm{~m}(3.75 \mathrm{ft}$.). Each makeup air vent consist of a lou-

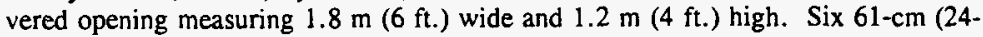
in.) by $61-\mathrm{cm}(24-\mathrm{in}$.) fiberglass filters with cardboard frames are provided over the interior side of each makeup air vent. The metal louvers for the makeup air vents are fixed in place.

Ventilation for Building 2403 WD is provided by four exhaust fans and ten makeup air vents. The fans are reported to be rated for 21,167 CFM and have metal back

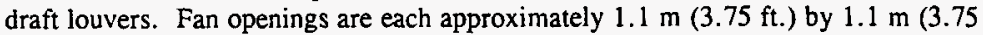
ft.). Each makeup air vent consist of a louvered opening measuring $1.8 \mathrm{~m}(6 \mathrm{ft}$.)

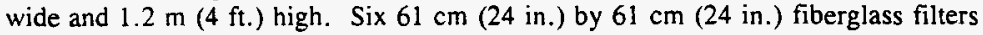
with cardboard frames are provided over the interior side of each makeup air vent. The metal louvers for the makeup air vents are fixed in place.

The LFMW Modules 20 and 21 are provided with forced mechanical ventilation by two small fans in the rear of the structure. There was no information available for these modules at the time of the survey; however, the fans are expected to be capable of providing approximately four air changes per hour. There was no indication that the CAM systems provide automatic shutdown of the exhaust fans to limit releases during a potential fire.

Manual exhaust fan disconnect switches are provided on the exterior sides of Buildings $2401 \mathrm{~W}, 2402 \mathrm{~W}$ through WL, and on the interior for Buildings $2403 \mathrm{WA}, \mathrm{WB}$, WC, and WD. Exhaust fans for Buildings 2403 WA, WB, WC, and WD are connected to the individual building's fire alarm panel. The building fire alarm panels provide automatic fan shutdown upon alarm condition by manual pull stations or sprinkler system water flow switches.

Since automatic fan shutdown is not provided for Buildings $2401 \mathrm{~W}$ and $2402 \mathrm{~W}$ through WL and LFMW Modules 20 and 21, products of combustion may continue to be exhausted during a fire until fans are manually shutdown. Consideration should be given to interlocking fans to shutdown upon sprinkler activation for Buildings $2401 \mathrm{~W}$ and $2402 \mathrm{~W}$ through WL and providing automatic fan shutdown by automatic fire detection or suppression activation for LFMW Modules 20 and 21. These fan interlocks would help to limit the quantity of products of combustion released during the initial phases of a potential fire incident. In addition, manual fan shutdown switches accessible to the fire department should be provided for Buildings 2403 WA, WB, WC, and WD as required by the Uniform Fire Code (UPC). Exterior manual exhaust fan switches located adjacent each fan are provided for Buildings $2401 \mathrm{~W}$ and $2402 \mathrm{~W}$ through $\mathrm{WL}$. 


\subsection{Essential Safety Class Systems}

There are no essential safety class systems identified in the Central Waste Complex Interim Safety Basis or the Central Waste Complex Final Safety Analysis Report. Einal Safety Analysis Document Upgrade documents.

\subsection{Fire Protection Features}

\section{a. Automatic Suppression System}

Automatic fire suppression for Buildings $2401 \mathrm{~W}$ and $2402 \mathrm{~W}$ through WL is provided by a single dry pipe automatic sprinkler system in each building. Automatic fire suppression for Buildings 2403 WA, WB, WC, and WD is provided by two dry pipe automatic sprinkler systems for each building with each half of the structure protected by a dry pipe system. Piping for the dry pipe sprinkler systems is sized in accordance with NFPA 13-1994 ordinary hazard pipe schedule or better. Grinnell Duraspeed ${ }^{1}$ sprinkler heads with a temperature rating of $141^{\circ} \mathrm{C}\left(286^{\circ} \mathrm{F}\right)$ are provided in the buildings.

Auxiliary drains are provided for drainage of trapped sections of the dry pipe sprinkler system which appear to be greater than $18.9 \mathrm{~L}$ ( 5 gal.). The auxiliary drains consist of a $2.5-\mathrm{cm}(1-$ in.) valve-and a plug. The capacity of the piping served by each auxiliary drain should be reviewed to determine if the pipe capacity is greater than $18.9 \mathrm{~L} \mathrm{(5} \mathrm{gal.).} \mathrm{If} \mathrm{the} \mathrm{capacity} \mathrm{of} \mathrm{the} \mathrm{piping} \mathrm{served} \mathrm{by} \mathrm{an}$ auxiliary drain is greater than $18.9 \mathrm{~L}$ (5-gal.), two $2.5-\mathrm{cm}$ (1-in.) valves and one $5.1-\mathrm{cm}$ by $30.5-\mathrm{cm}$ (2-in. by $12-\mathrm{in}$.) condensate nipple or equivalent should be provided for the auxiliary drain to comply with NFPA 13 requirements.

Water supply is provided as described above under the Description of Construction section. Post indicator valves (PIVs) are located in each sprinkler lead-in line and at each main supply line loop intersection. An underground gate valve with a roadway box is provided for the long supply line (loop leg) on the west of CWC (refer to Drawing H-2-80896).

The dry pipe valves are located in insulated valve houses with permanently mounted electrical resistance-type heaters. Portable electric resistance typeheaters are also provided for extremely cold periods which occur approximately four to five weeks per year. Additionally, permanently installed heater capacity should be provided and valve house insulation should be improved so that portable heaters are not needed.

Tamper switches and valve seals are provided for the two gate valves at each double check valve assembly (two check valve assemblies within the fenced CWC storage area) and for each PIV (ref. Drawing H-2-80896). Electronic valve supervision is provided to the site fire department directly through the GH Harlow 
Co. radio fire alarm transmitters (Hanford Boxes $\# 2860,2862$, and 2864) forPIVs at Buildings $2401 \mathrm{~W}$ and $2402 \mathrm{~W}$ through $\mathrm{WL}$ and valves for the south double check valve assembly. PIVs for Buildings 2403 WA, WB, WC, and WD and valves at the north double check valve assembly are monitored by the site fire department through the Pyrotronics ${ }^{2}$ Model CP-400 Fire Alarm Control Panels. Fire alarm panels are located at Buildings 2403 WA, WB, WC, and WD, which are connected to a GH Harlow Co. radio fire alarm transmitter (Hanford Box \#2866).

A water flow pressure switch, a low temperature switch, and a low air pressure switch are provided at each dry pipe valve (ref. Drawings H-2-131543, H-280741-Sheets 1 and 2, H-2-80903, H-2-80902-Sheets 2 and 3, and H-2-131542). The low temperature and low air pressure supervision and water flow alarms are transmitted to the site fire department directly through the GH Harlow Co. radio fire alarm transmitters (Hanford Boxes $\$ 2860,2862$, and 2864) for Buildings $2401 \mathrm{~W}$ and $2402 \mathrm{~W}$ through WL. Low temperature and low pressure supervision and water flow alarms for Buildings 2403 WA, WB, WC, and WD are monitored by the site fire department through the Pyrotronics Model CP-400 Fire Alarm Control Panels which are connected to a GH Harlow Co. radio fire alarm transmitter (Hanford Box \#2866).

The dry pipe sprinkler systems were analyzed against NFPA 13 requirements for Ordinary Hazard Occupancies (Group 1). Since the quantity of combustibles exposed in buildings is moderate due to storage being in metal containers, the potential fires will result in moderate rates of heat release. The analysis is based on a minimal quantity of exposed plastics in the moderate and large size buildings (Buildings 2403 WA, WB, WC, and WD) with no exposed plastic in the small size buildings (Buildings $2401 \mathrm{~W}$ and $2402 \mathrm{~W}$ through WL) without approval by the Hanford Fire Protection Engineering Organization.

At the time of the initial survey, there were exposed plastics at the CWC Buildings consisting of plastic pallets and polyethylene overpacks containing steel drums. However, plastic pallets are no longer used, and polyethylene overpacks are now overpacked in steel containers.

NFPA 231-1990 recommends using NFPA 13, Ordinary Hazard, Group 3 (equivalent to Ordinary Hazard, Group 2 in NFPA 13-1994) sprinkler design requirements for Group B plastics and free-flowing group A plastics in storage. NFPA 231 does not address a commodity classification for materials stored in noncombustible containers but the fire hazard is less than that expected for a Class IV commodity with exposed combustible plastics. Since combustible material is stored in metal drums and metal boxes, and polyethylene overpacks and plastic pallets have been restricted, Ordinary Hazard, Group 1 sprinkler design requirements are considered adequate protection. 
NFPA 13-1994, Figure 5-2.3 requires a sprinkler design density of approximately $4.9 \mathrm{lpm} / \mathrm{sq}$. m. (0.12 gpm/sq. ft.) for a $285.9 \mathrm{sq} . \mathrm{m}$. (3,077 sq. ft.) sprinkler design area [increased to $371.6 \mathrm{sq} . \mathrm{m}$. (4,000 sq. ft.) for a dry pipe system] for an Ordinary Hazard, Group 1 sprinkler system. Figure 5-2.3 also requires a sprinkler design density of approximately $6.1 \mathrm{lpm} / \mathrm{sq} . \mathrm{m} .(0.15 \mathrm{gpm} / \mathrm{sq}$. ft.) for a 139.4 sq. m. (1,500 sq. ft.) sprinkler design area [increased to $181.2 \mathrm{sq} . \mathrm{m}$. (1950 sq. ft.) for a dry pipe system] for an Ordinary Hazard, Group 1 sprinkler system.

The sprinkler systems were analyzed using the hydraulic model Sedan. Water flow information was provided by the Hanford Fire Department (static 110 psi, residual $55 \mathrm{psi}$, flow $1,652 \mathrm{gpm}$ ). Sprinkler layout drawings were also provided by Westinghouse Hanford Site personnel. The representative analysis for Buildings $2401 \mathrm{~W}$ and $2402 \mathrm{~W}$ through WL was evaluated over both a $285.9 \mathrm{sq} . \mathrm{m}$. (3,077 sq. ft.) and a 139.4 sq. $\mathrm{m}$. (1,500 sq. ft.) area with a 30 percent increase in area to 371.6 sq. m. ( 4,000 sq. ft) and 181.2 sq. m. (1,950 sq. ft.) for the dry pipe valve as required by NFPA 13-1994, Section 5-2.3.2.3. It was determined that the sprinkler systems are not capable of providing the required density of $4.88 \mathrm{lpm} / \mathrm{sq} . \mathrm{m}$. $(0.12 \mathrm{gpm} / \mathrm{sq}: \mathrm{ft}$.) with a $946 \mathrm{lpm}(250 \mathrm{gpm})$ hose demand for the 371.6 sq. $\mathrm{m} .(4,000 \mathrm{sq} . \mathrm{ft}$.) demand area but are capable of providing a density of $6.3 \mathrm{lpm} / \mathrm{sq} . \mathrm{m}$. $(0.155 \mathrm{gpm} / \mathrm{ft}$. sq) with a $946 \mathrm{lpm}(250 \mathrm{gpm})$ hose demand for the 181.2 sq. $m$. (1,950 sq. ft.) demand area.

Hydraulic analyses indicates that these sprinkler systems cannot meet minimum density requirement with a $1,892 \mathrm{lpm}(500 \mathrm{gpm})$ hose stream allowance as required by $6430.1 \mathrm{~A}$.

The representative analysis for Buildings 2403 WA, WB, and WC was evaluated over a 139.4 sq. $\mathrm{m}$. (1,500 sq. ft.) area with a 30 percent increase in area to $181.2 \mathrm{sq}$. $\mathrm{m}$. (1,950 sq. ft.) for the dry pipe valve as required by NFPA 13-1994, Section 5-2.3.2.3. The sprinkler system was determined to be capable of providing a density of $8.2 \mathrm{lpm} / \mathrm{sq} . \mathrm{m} .(0.20 \mathrm{gpm} / \mathrm{sq}$. ft.) with a $1,892 \mathrm{lpm}(500 \mathrm{gpm})$ hose demand.

The representative analysis for Building 2403 WD was also evaluated over a 139.4 sq. $\mathrm{m}$. (1,500 sq. ft.) area with a 30 percent increase in area to $181.2 \mathrm{sq}$. $\mathrm{m}$. (1,950 sq. ft.) for the dry pipe valve as required by NFPA 13-1994, Section 5-2.3.2.3. The sprinkler system was determined to be capable of providing a density of $8.4 \mathrm{lpm} / \mathrm{sq} . \mathrm{m}$. $(0.21 \mathrm{gpm} / \mathrm{sq}$. ft. $)$ with a $1,892 \mathrm{lpm}(500 \mathrm{gpm})$ hose demand.

Based on the hydraulic analysis, the sprinkler systems are considered adequate to provide quick automatic fire control for Ordinary Hazard, Group 1 occupancies. The existing sprinkler systems are adequate to meet NFPA 13-1994 requirements. Sprinkler systems or water supply will need to be altered if an Ordinary Hazard, 
Group 1 minimum design density and a $1,892 \mathrm{lpm}(500 \mathrm{gpm})$ hose stream allowance is to be achieved as required by DOE 6430.1 A.

For Buildings $2401 \mathrm{~W}$ and $2402 \mathrm{~W}$ through WL, the most remote $181.2 \mathrm{sq} . \mathrm{m}$. $(1,950$ sq. ft.) area with a $946 \mathrm{lpm}(250 \mathrm{gpm})$ hose stream requires $152,364.2$ liters $(40,308$ gallons) total water demand based on a 60 -minute duration. The most remote $181.2 \mathrm{sq} . \mathrm{m}$. (1,950 sq. ft.) area with a $1,892 \mathrm{lpm}(500 \mathrm{gpm})$ hose stream for Buildings 2403 WA, WB, and WC requires 228,002 liters $(60,318$ gallons) and for Building WD requires 233,853 liters ( 61,866 gallons) based on a 60 -minute duration.

The 200-West area has two clearwells each with a storage capacity of 756,000 liters $(200,000$ gallons) of potable water. In addition, there is a 756,000 liter $(200,000-\mathrm{gal}$.$) raised tank on the potable distribution system. The pumping$ capacities from the clearwells to the potable water distribution piping consist of three $3,780 \mathrm{lpm}(1,000 \mathrm{gpm})$ electric pumps, one $2,268 \mathrm{lpm}(600 \mathrm{gpm})$ electric pump, one $3,780 \mathrm{lpm}(1,000 \mathrm{gpm})$ steam pump, and two $2,268 \mathrm{lpm}(600 \mathrm{gpm})$ steam pumps (ref. Fire Protection Program Manual, Water Supplies, WHC-CM4-41, August 17,1992 ). The three steam pumps provide standby capacity and automatically start when the water pressure in the potable supply main drops below $59563.5 \mathrm{kgs} / \mathrm{sq}$. m. ( $85 \mathrm{psi})$. Based on the hydraulic analysis, the existing water supply for the CWC area appears to meet the objectives of DOE 5480.7A, requirements for a highly protected risk, and NFPA 13-1994 requirements. Analysis of the water supply facilities is based on document review and interviews with WHC representatives and did not include a detailed physical inspection of the water supply equipment.

The LFMW and AMW Modules 3, 4, 5, 6, 7, 8, 11, 12, 13, 14, 15, 18, 19, 22, and 23 are provided with automatic, total-flooding dry chemical systems. (Note: dry chemical cylinders are not connected for automatic fire suppression systems in the AMW Modules since the dry chemical agent provided is not the correct type for combustible metal fires.) These dry chemical systems are activated by $100^{\circ} \mathrm{C}\left(212^{\circ} \mathrm{F}\right)$ fusible links. The site fire department is not currently capable of monitoring the dry chemical system for activation; however, Westinghouse Hanford Company personnel indicated that consideration is being given to connecting the dry chemical systems to a radio fire alarm transmitter such that the site fire department can monitor alarm and trouble conditions. Consideration should be given to connecting the dry chemical systems provided for the modules identified above to the site fire department in order to initiate prompt fire department response. In addition, consideration should be given to providing automatic fire suppression for the remaining modules which do not have automatic fire suppression (Modules 1, 2, 9, 10, 16, 17, 20, and 21).

Some LFMW Modules are provided with sprinkler piping that is not connected to a water supply. The fire department can connect hose to the LFMW module 
sprinkler systems to provide a water supply. The manual sprinkler systems are not accredited to providing any additional fire suppression capability for the LFMW Modules.

\section{b. Hydrants}

Fire hydrants IWF through 9WF located within the CWC fenced area and hydrant 4WA located outside the CWC fenced area near Building $213 \mathrm{~W}$ provide adequate coverage for the CWC area. Exterior sides of all storage buildings and modules and the edge of the Mixed Waste Storage Pad can be reached with a 300 $\mathrm{ft}$. hose lay. Fire Hydrants $4 W F$ and $5 W F$ are fed from a $30.5 \mathrm{~cm}$ (12 in.) main, IWF, 2WF, 3WF, 6WF, AND 7WF are fed from a $25.4 \mathrm{~cm}$ (10 in.) main, and $4 \mathrm{WA}, 8 \mathrm{WF}$, and $9 \mathrm{WF}$ are fed from an $20.3 \mathrm{~cm}(8 \mathrm{in}$.) main. All water supply mains for fire suppression at the CWC are looped. The location and number of fire hydrants within the area appears to be adequate in meeting NFPA 24-1994.

c. Manual Fire Fighting

Portable, $4.5 \mathrm{~kg}$ (10-pound), multi-purpose dry chemical fire extinguishers are provided throughout the buildings and at the LFMW and AMW module pad area. In addition, a $13.6 \mathrm{~kg}$ (30-pound), $\mathrm{NaX}$ dry powder extinguisher is provided at each of the AMW Modules. Fire extinguishers appear to be adequately located and of sufficient number and type to meet NFPA 10-1994.

The Building Emergency Plan for the Central Waste Complex, WHC-IP-0263CWC, Westinghouse Hanford Company, dated August 31, 1993 provides the following instructions for unit occupants responding to a fire incident. "Evacuate the facility and stand by for further instructions." All personnel have received hands-on fire extinguisher training and also received fire extinguisher retraining consisting of a video tape review.

\section{d. Fire Alarm System}

The fire alarm system for Buildings 2403 WA, WB, WC, and WD consists of a Pyrotronics CP-400 Fire Alarm Control Panel at each building. Each CP-400 Fire Alarm Control Panel provides four Class B, NFPA Style A and B capability, detection zones and two Class B, NFPA Style A and B capability, audible circuits. The CP.400 Fire Alarm Control Panels are connected to a GH Harlow Co., GHR02 Radio Fire Alarm Transmitter (Hanford Box \$2866). Manual pull stations located adjacent to each pedestrian door and water flow pressure switches provide a means for alarm activation. The low pressure, low temperature, and tamper switches are also connected to the detection zones and provide an open circuit trouble condition upon activation. These devices are installed as a NFPA Style B detection circuit. The panel provides occupant emergency notification through alarm bells connected to each panel. The fire alarm control panels are 
also connected to the exhaust fan starters in order to shutdown exhaust fans upon. alarm condition.

The fire alarm system for Buildings $2401 \mathrm{~W}$ and $2402 \mathrm{~W}$ through WL consist of the GH Harlow Co., GHR02 Radio Fire Alarm Transmitters (Hanford Boxes 2860,2862 , and 2864). Manual pull stations and water flow alarm devices as well as low temperature, low pressure, and valve tamper supervisory devices are connected directly to the Radio Fire Alarm Transmitters. The supervisory devices provide an open circuit trouble condition upon activation. There is no indication of an automatic exhaust fan shutdown interlock for Buildings $2401 \mathrm{~W}$ and $2402 \mathrm{~W}$ through WL.

The GH Harlow Co., GHR02 Radio Fire Alarm Transmitters are designed to supervise the signal contacts for ground fault and short circuit. The system is capable of providing an alarm with one ground fault. The Base Station Model GHRD02 monitors the radio frequency to ensure a clear communications link between the transmitter and receiver. The receiver reports trouble if frequencies are not clear. The transmitter also sends a test signal once every 24 hours. If the transmitter does not receive a test signal from a specific transmitter box, an error message summary is created and sent by the receiver to the site fire department every 24 hours (at 9:00 AM the summary sheet is automatically printed and appears on the computer screen at the Station 2 Control Center). The transmitter and receiver are also capable of supervising for low battery power and loss of main power. Two receivers are provided for redundancy (one in the Gable Mountain Microwave Shack and one at the 300-area fire station). The signals are transmitted to the site microwave system by both receivers with redundant signals transmitted over dedicated telephone lines to the four site fire departments. As a third backup, Stations 1, 2, and 3 have antennae on the buildings that pick up the signal directly from the radio transmitter boxes. Each of the four site fire department stations has a Radio Fire Alarm Receiver (RFAR) computer which can decode signals into a box number, a zone, and a specific message. The RFAR computer passes the signal information to the computer-aided dispatch (CAD) system for response action (ring house bells, raise the doors, turn on lights, and activate the traffic light at all four stations). If the CAD system should fail, the RFAR system can be used in a stand-alone mode as a fire alarm receiving system.

The CAD system consists of Compaq 386 computers running OS2 as an operating system. Using OS2 allows the computers to run multiple screen sessions, tasks, and threads (multi-task). The CAD system's primary function is dispatching equipment to emergencies. At the time of dispatch, specific information as to which apparatus to send, what hazards may be found in the building, what exposures may be affected by a fire, and a graphic floor plan of the fire zone are sent to the stations and to the responding vehicles. Fire department personnel at Station 1 indicated that the on-board computers in response vehicles 
are not reliable. Typically the fire department control center dispatcher relays. response information by radio.

The CAD and RFAR systems at Station 2 are set up in a redundant fashion, with two separate systems.

Electrical power backup is provided by dedicated battery banks at the Fire Alarm Control Panels, the Radio Fire Alarm Transmitters (Boxes \#2860, 2862, 2864, and 2866), and RFARs. Each CAD and RFAR system at Station 2 is powered through a separate uninterruptable power supply (UPS). A propane-powered generator provides backup AC power supply, as well as the 4 hours of battery supply through the UPSs for the RFAR and CAD computers at Station 2 (Ref. Drawing H-2-131543, H-2-80741 Sheets 1 and 2, and H-2-80903, Fire Alarm Receiving System Hanford Fire Department write-up, Pyrotronics and GH Harlow manufacturer data sheets, and Telephone Conversation Summary, Name Mack Knight, Recorded by: D.T. Brown, 9-16-94).

Based on the maintenance list provided by the Hanford Fire Department, the Pyrotronics fire alarm control panels and radio fire alarm transmitters have experienced low failure rate.

\subsection{Description of Fire Hazards}

Buildings $2401 \mathrm{~W}$ and $2402 \mathrm{~W}$ through WL are capable of containing a maximum of approximately 1,000 drums stored three high on wood pallets. Use of plastic pallets has been discontinued throughout the CWC. These buildings are used for storage of hazardous mixed wastes contaminated with various radioactive isotopes. At the time of the survey, Building $2401 \mathrm{~W}$ was only approximately 10 percent filled with large metal storage boxes stored one high and storage within Buildings $2402 \mathrm{~W}$ through WL ranged from approximately full in five buildings to no storage in two buildings. The other five $2402 \mathrm{~W}$ through WL Buildings were 25 to 50 percent filled. Each of the buildings are identified for various types of material storage (i.e. oxidizers, caustics, etc.).

Buildings 2403 WA, WB, and WC are capable of containing a maximum of approximately 12,000 drums stored three high on wood pallets. The buildings are used to store hazardous mixed wastes contaminated with various radioactive isotopes. At the time of the survey, these buildings were approximately 50 to. 75 percent full.

Building $2403 \mathrm{WD}$ is capable of containing a maximum of approximately 19,000 drums stored three high on wood pallets. This building is also used to store hazardous mixed wastes contaminated with various radioactive isotopes. At the time of the survey, the building was approximately 10 percent full. 
Storage within Buildings $2401 \mathrm{~W}, 2402 \mathrm{~W}$ through WL, and $2403 \mathrm{WA}, \mathrm{WB}, \mathrm{WC}$, and WD can consist of approximately 10 percent transuranic-type drum storage.. Each transuranic waste storage drum may contain up to 200 grams of plutonium. In addition, a minimum $3 \mathrm{ft}$. aisle width is maintained between storage container piles so that containers can be inspected on a regular basis.

Typical fire hazards for Buildings $2401 \mathrm{~W}, 2402 \mathrm{~W}$ through WL, and $2403 \mathrm{WA}$, WB, WC, and WD consist of a fire resulting from an initiating drum failure event, modeled in Appendix B of this report, with fire spreading to adjacent wood pallets. Full scale drum tests (Section 5.0, reference "o") indicated that an unmitigated fire can propagate slowly through the drum stack from burning wood pallets until either an aisle or fire stop is reached. As witnessed in the drum fie tests, drum banding at the CWC helps prevent pile instability, so that drums do not fall from the second and third levels and propagate fire between piles.

Large metal storage boxes are also stored a maximum of two high within Buildings $2401 \mathrm{~W}, 2402 \mathrm{~W}$ through WL, and $2403 \mathrm{WA}, \mathrm{WB}, \mathrm{WC}$, and WD. The top layer of metal boxes are stored directly on top of the lower layer with no combustible materials such as wood pallets. Due to the greater amount of energy required to heat up the larger container and contents to cause pyrolysis, the drums were identified as the bounding source for fire propagation in the Appendix B fire modeling.

Fire modeling indicates that the sprinkler system will activate in a maximum credible fire loss (MCFL) type fire scenario to reduce the gas layer temperatures and suppress the fire prior to the roof structural steel members reaching critical failure temperatures. Based on the limited rate of fire propagation seen in the drum fire tests (Section 5.0, reference "o"), major structural failure is not anticipated for a MFLtype scenario.

The LFMW Modules are used to store flammable LLW, LL-MW, TRU, and TRUMW with flashpoints below $37.8^{\circ} \mathrm{C}\left(100^{\circ} \mathrm{F}\right)$. The total capacity within all LFMW Modules consist of approximately three hundred and sixty 208-L (55 gal.) drums. The largest LFMW Modules (LFMW Modules 3 and 11) can each accommodate approximately thirty-three 208-L (55-gal.) drums (eleven drums per compartment). LFMW Modules 20 and 21 are used to store TRU and TRU-MW and can each accommodate approximately eighteen $208-\mathrm{L}$ (55-gal.) drums.

Moderate releases of combustion products may be expected from a MCFL- or MFLtype scenario at LFMW Modules 1, 2, 9, 10,16, 17, 20, and 21, since automatic fire suppression is not provided for these modules. In addition, delayed fire department notification may also occur since modules provided with automatic dry chemical systems are not connected through the radio fire alarm transmitters to the site fire department. Fire modeling indicates that fire propagation is not expected between modules for a MCFL- or MFL-type scenario, (reference Appendix B) based on a minimum 15 foot spacing between modules (Refence Appendix $D$ ). 
The Mixed Waste Storage Pad is used for short-term storage until material can be moved to the storage buildings or modules. At the time of the survey, large wood waste storage boxes were being stored on the Mixed Waste Storage Pad. Since the initial survey, administrative controls have been implemented to prevent storage of combustibles on the Mixed Waste Storage Pad. Therefore, storage at the Mixed Waste Storage Pad is limited to metal boxes and metal drums containing combustible and noncombustible materials. Since there are no exposed combustible materials at the Mixed Waste Storage Pad, the fire hazard is considered a low exposure.

Propane forklifts used at the CWC present a fire hazard resulting from a propane leak and exposure fire. At the time of the survey there were no shrouds provided to protect the flexible propane line and tank from damaged by a falling drum. This initiating fire is identified in Appendix B of this report. Consideration should be given to providing protective shrouds over the propane tank and flexible propane hose for forklifts at the CWC to protect the tanks and hoses from potential damage from a falling drum. The shrouds should be partially open to prevent a buildup of propane within the protective cover.

Ignition sources at the CWC are controlled by prohibiting smoking and limiting personnel access. The Hanford Site also has procedures to control hot work and portable heaters and to provide fire watches in facilities where fire protection systems are out of service (ref. Fire Protection Program Manual, WHC-CM-4-41).

\subsection{Life Safety Considerations}

The Buildings $2401 \mathrm{~W}, 2402 \mathrm{~W}$ through WL, and $2403 \mathrm{WA}, \mathrm{WB}, \mathrm{WC}$, and WD at the CWC are considered high-hazard Storage Occupancies as defined under NFPA 101 and Group H, Division 7 Occupancies as defined under the Uniform Building Code (High hazard requirements apply due to the extremely toxic nature of expected combustion products.) Means of egress from Buildings $2401 \mathrm{~W}$ and $2402 \mathrm{~W}$ through WL is provided by two remotely located pedestrian doors. Travel from any point within the structures to an exit is less than the maximum $30.5 \mathrm{~m}$ (100 ft.) of travel required by NFPA 101 . There are no common paths of travel within these structures.

Means of egress from Buildings $2403 \mathrm{WA}, \mathrm{WB}$, and WC is provided by four remotely located pedestrian doors. Travel from any point within the structures to an exit is less than the maximum $30.5 \mathrm{~m}$ (100 ft.) of travel required by NFPA 101. There are no common paths of travel within these structures.

Means of egress from Building 2403 WD is provided by six remotely located pedestrian doors. Travel from any point within the structure to an exit is less than the maximum $30.5 \mathrm{~m}$ (100 ft.) of travel required by NFPA 101 . There are no common paths of travel within this structure. 
At the time of the survey, sufficient self-illuminous exit signs appeared to be adequately located to direct occupants to the nearest exit. A test of the emergency lighting was not conducted to confirm compliance with NFPA 101 requirements. Battery powered emergency lighting is provided for Buildings $2401 \mathrm{~W}$ and $2402 \mathrm{~W}$ through WL, and 2403 WA, WB, WC, and WD. Emergency lighting provisions appear to be adequate to meet NFPA 101 requirements based on visual observation.

\subsection{Critical Process Equipment}

There is no critical process equipment at the CWC. Due to the nature of the operations conducted at the CWC, an interruption in operations due to a fire is not expected to affect vital DOE programs.

\subsection{High Value Property}

Facility Replacement Costs:

\section{Structures:}

Buildings $2401 \mathrm{~W}$ and $2402 \mathrm{~W}$ through $\mathrm{WL}-\$ 160,000$ per building Buildings $2403 \mathrm{WA}, \mathrm{WB}$, and WC $-\$ 1,360,000$ per building Building 2403 WD $-\$ 2,210,000$

LFMW and AMW Modules - $\$ 15,000$ to $\$ 20,000$ per module Mixed Waste Storage Pad - $\$ 30,000$

Structure values are based on a metal pre-engineered building similar to existing structures at $\$ 40 / \mathrm{sq}$. $\mathrm{ft}$., and assume that the floor of the building is intact and usable. If the floor of the structure is expected to need replacing, the structure value should be calculated using $\$ 50 / \mathrm{sq}$. $\mathrm{ft}$.

Module values are based on storage module costs estimated by manufacturers.

\subsection{Damage Potential}

Fire hazard severity and probabilities were modeled for MCFL and MFL fire incident scenarios in Appendix B.

MCFL evaluation assumes the automatic operation of the sprinkler system. Based on the modeled sprinkJer activation times in Appendix B and expected quick fire control, potential release of PU species outside the CWC Buildings evaluated in this report represents a small exposure potential. Probabilistic release quantities are estimated in Section 5.0 of Appendix B of this report.

MCFL damage potential in the sprinklered protected CWC Buildings would be limited to the immediate area of fire origin and damage restoration costs would be 
primarily associated with internal building cleanup and decontamination near the area of fire origin. Outside cleanup and decontamination costs should be minor. For nonprotected CWC Storage Modules, MCFL is equal to MFL.

MFL evaluation assumes the automatic sprinkler system fails and the responding fire department is effective in controlling the fire.

Based on the modeled fire department's fire suppression times in Appendix B, MFL damage potential for the CWC Buildings evaluated in this report would be generally limited to the storage array of fire origin and damage restoration costs would be primarily associated with internal building cleanup and decontamination within the building area. For the MFL incident, the potential release of PU species outside the bujldings, as estimated in Section 5.0 of Appendix B, represent a small exposure potential and cleanup costs should be minor. MFL damage to the CWC Modules evaluated in this report would involve the entire module, with moderate cleanup costs.

MFL loss estimates are presented in Table 7.8-1. The estimated direct internal loss column indicates internal fire and smoke damage and internal cleanup costs. For Buildings $2401 \mathrm{~W}$ and $2402 \mathrm{~W}$ through WL, the MFL internal direct loss was estimated at 40 percent of the building value. Included in the $40 \%$ is ten percent for internal building cleanup costs.

For Building 2403 WA, WB, WC, and 2403 WD, the MFL internal direct loss was estimated at 20 percent of the building value. Included is the $20 \%$ is ten percent for internal building cleanup costs.

Estimating the internal cleanup costs at ten percent of the value of the building is based on the reference WHC-SD-W112 FHA 001, "Fire Hazards Analysis for the Enhanced Radioactive and Mixed Waste Storage Facilities".

MFL external cleanup costs in Table 7.8-1 were estimated by Kent McDonald, January 29, 1996, in a document identified as, "Estimation of External Ground Contamination from Maximum Foreseeable Scenarios".

MCFL loss estimates for the buildings listed in Table 7.8-1 can be approximated at $30-35 \%$ of the MFL total loss expectancy estimates. 


\begin{tabular}{|c|c|c|c|c|}
\hline \multicolumn{5}{|c|}{$\begin{array}{c}\text { Table } 7.8-1 \\
\text { MAXIMUM FORESEEABLE LOSS ESTIMATES }\end{array}$} \\
\hline BUILDING & $\begin{array}{l}\text { FLOOR } \\
\text { AREA }\end{array}$ & $\begin{array}{c}\text { ESTIMATED } \\
\text { DIRECT } \\
\text { INTERNAL LOSS }\end{array}$ & $\begin{array}{c}\text { ESTIMATED } \\
\text { EXTERNAL } \\
\text { CLEANUP COST }\end{array}$ & $\begin{array}{r}\text { TOTAL LOSS } \\
\text { EXPECTANCY }\end{array}$ \\
\hline $2401 \mathrm{~W}$ & $\begin{array}{c}371 \mathrm{~m}^{2} \\
\left(4,000 \mathrm{ft}^{2}\right) \\
\end{array}$ & $\$ 64,000$ & $\begin{array}{ll}{[1]} & \$ 121,600 \\
{[2]} & \$ 153,900 \\
\end{array}$ & $\begin{array}{l}\$ 185,600 \text { to } \\
\$ 217,900\end{array}$ \\
\hline $2402 \mathrm{~W}-\mathrm{WL}$ & $\begin{array}{c}371 \mathrm{~m}^{2} \\
\left(4,000 \mathrm{ft}^{2}\right)\end{array}$ & $\$ 64,000$ & \begin{tabular}{|ll}
$11]$ & $\$ 121,600$ \\
{$[2]$} & $\$ 153,900$
\end{tabular} & $\begin{array}{l}\$ 185,600 \text { to } \\
\$ 217,900\end{array}$ \\
\hline $\begin{array}{l}2403 \text { WA, } \\
W B \text {, and WC }\end{array}$ & $\begin{array}{c}3,160 \mathrm{~m}^{2} \\
\left(34,000 \mathrm{ft}^{2}\right)\end{array}$ & $\$ 272,000$ & $\begin{array}{llr}{[1]} & \$ 83,300 \\
{[2]} & \$ 132,300\end{array}$ & $\begin{array}{l}\$ 355,300 \text { to } \\
\$ 404,300\end{array}$ \\
\hline 2403 WD & $\begin{array}{r}5,128 \mathrm{~m}^{2} \\
\left(55,250 \mathrm{ft}^{2}\right) \\
\end{array}$ & $\$ 442,000$ & $\begin{array}{ll}{[1]} & \$ 62,400 \\
{[2]} & \$ 129,000 \\
\end{array}$ & $\begin{array}{l}\$ 504,400 \text { to } \\
\$ 571,000\end{array}$ \\
\hline $\begin{array}{l}\text { LFMW } \\
\text { Modules }\end{array}$ & $\begin{array}{c}\text { Varies/ } \\
23.5 \mathrm{~m}^{2} \\
\left(256 \mathrm{ft}^{2}\right) \\
\max .\end{array}$ & $\$ 20,000$ & {$[3] \quad \$ 76,950$} & $\$ 96,950$ \\
\hline $\begin{array}{l}\text { AMW } \\
\text { Modules }\end{array}$ & $\begin{array}{l}19.7 \mathrm{~m}^{2} \\
\left(216 \mathrm{ft}^{2}\right) \\
\end{array}$ & $\$ 20,000$ & {$[3] \quad \$ 76,950$} & $\$ 96,950$ \\
\hline \multicolumn{5}{|c|}{$\begin{array}{l}\text { NOTES: Estimated External Cleanup Costs } \\
\text { [1] Building ventilation system off } \\
\text { [2] Building ventilation system on } \\
\text { Extemal cleanup cost estimations provided by Kent McDonald, } 1 / 29 / 96 \text { (document identified as } \\
\text { Estimation of External Ground Contamination from Maximum Foreseeable Fire Scenarios). } \\
\text { [3] Estimated as } 50 \% \text { of the extemal cleanup costs associated with } 2401 \text { WW Building with } \\
\text { ventilation on }(50 \% \times \$ 153,900)\end{array}$} \\
\hline
\end{tabular}

\subsection{Fire Department Response}

\section{a. Method of Alarms and Communications}

The primary method for the Hanford Fire Department to receive an alarm from the CWC is through the radio fire alarm transmitter and receivers as described above in the Fire Protecrion Fearures section. Manual pull stations within the CWC Buildings, water flow alarms, and the fire department call buttons at the radio fire alarm transmitters (Hanford Boxes \# 2860, 2862, 2864, and 2866) are transmitted to the fire department through Transmitters $2860,2862,2864$, and 2866. Alarms may also be transmitted by dialing 911 on telephones connected to the Hanford Site telephone network. 
Hanford Fire Department personnel are provided with 16-channel portable radios* for communication with the Fire Department Central Control Center or other fire department personnel. The Hanford Fire Department also has radio channels to communicate with mutual aid fire departments. Computers and printers are provided on first line response vehicles for transmitting facility pre-fire plan information from the CAD system; however, the vehicle on-board computer system is unreliable.

Fire department notification methods and the fire department communications system are adequate if pre-fire plans are made available to response personnel at the scene.

\section{b. Staffing. Training, and Equipment}

A Deputy Chief and Battalion Chief are on duty during day-shift weekdays. A Battalion Chief is on call during off-shift hours. Each of the four stations is continuously staffed by three or four fire fighters and a captain. Two medically trained personnel [emergency medical technician (EMT) and a paramedic] are also continuously on duty. Additional staffing during day-shift weekdays consists of approximately 28 fire fighters in the inspection and testing group. During offshift hours, a minimum of 20 fire fighters are available from the four site fire stations (maximum of 24 fire fighters).

The Hanford Site Fire Department also has mutual agreements with surrounding communities.

Fire fighters are qualified to minimum fire fighter level 1, and officers are trained to officer level 1 and instructor level 1. All fire fighters are trained as rad workers.

The Hanford Fire Department maintains a total of 35 vehicles representing diverse capabilities. Some of this emergency equipment was specifically designed to control situations unique to the Hanford Site. The vehicles (by station) are located in Table 7.9.

One aerial ladder pumper is located in each of the four fire stations, with ladder sizes ranging from 50 to 75 feet. These units have turbo-charged Detroit diesel engines and Allison automatic transmissions. They are equipped with 1,500 or $2,000 \mathrm{gpm}$ pumps, with the capability of discharging $1,000 \mathrm{gpm}$ from the aerial ladder nozzle. Operation of the ladder nozzle can be controlled from atop the ladder or remotely. The pumper carries 4 -inch hose for water supply and the aerial ladder for rescue, protection of adjoining buildings, or extinguishment of fires. 


\begin{tabular}{||l|l|l|l||}
\hline \multicolumn{4}{|c|}{ EMERGENCY EQUIPMENT BY STATION } \\
\hline \multicolumn{1}{|c|}{ Station 1 } & \multicolumn{1}{|c|}{ Station 2 } & \multicolumn{1}{c|}{ Station 3 } & \multicolumn{1}{c|}{ Station 4 } \\
\hline Engine 91 & Engine 92 & Engine 93 & Engine 94 \\
\hline Engine 912 & Engine 922 & Engine 932 & Medic 94 \\
\hline Pumper/tanker 91 & Pumper/tanker 92 & Pumper/tanker 93 & Pumper/tanker 94 \\
\hline Tender 91 & Hazmat 92 & Rescue 93 & Cascade 94 \\
\hline Mass Casualty 91 & Aid 922 & Pumper/tanker 932 & Chemical 94 \\
\hline Grass 91 & Grass 92 & Grass 93 & Grass 94 \\
\hline Chief 91 & Attack 92 & Aid 932 & \\
\hline & Pumper/tanker 922 & & \\
\hline
\end{tabular}

Each station is also equipped with a pumper truck with a 600 gallon water tank and a 1,500 gpm pump. These trucks are also turbo-charged diesel-powered, with automatic transmissions. They are equipped as fire pumpers per NFPA 1901.

Six modular ambulances are located on site, with one assigned as first response in each fire station. The remaining two ambulances are used as spares when the front line units are in for repair or otherwise out of service. These ambulances are equipped for radio communications with the local hospital emergency room. All ambulances are licensed by Washington State Emergency Services and carry medical supplies and equipment to allow attendants to provide advanced life support.

A diesel-powered water tanker with a $450 \mathrm{gpm}$ pump capable of carrying 5,000 gallons of water is housed at the 100 station. This unit is primarily used to supply brush tankers during range fire activities.

Four 4-wheel-drive command vehicles are in service. Each is equipped with multi-channel radios and cellular phones to aid in communicating with on-site emergency organizations and mutual aid fire departments. Each vehicle carries firefighting gear and specialized equipment to allow establishment and operation of a field command post, including personnel accountability equipment.

Four grass trucks are equipped with portable fire pumps and 200-gallon water tanks. These units provide quick attack capability for extinguishing small spot 
fires. They aiso have AFFF foam on board using an induction system. Each station is assigned one grass truck.

A Triple Combination Fast Attack Truck, ATT-92, is equipped with 300 gallons of premix AFFF foam, 300 gallons of AFFF concentrate, and 450 pounds of dry chemical. This unit can discharge AFFF foam and dry chemical at the same time through a dual barrel turret mounted on the roof. All agents can also be discharged through handlines. This truck has a single stage $350 \mathrm{gpm}$ pump that, when used in conjunction with the 300 gallons of AFFF pure concentrate foam, can produce 10,000 gallons of workable firefighting foam. This unit is utilized for light aircraft, electrical, and flammable liquid fires.

A chemical response truck, CHEM-94, is used for pyrophoric metal fires, such as sodium and lithium. It is equipped with a 500-pound container of carbon microspheres and a 1,000 pound container of NAX dry chemical.

Six brush tankers are used for rangeland firefighting and in areas with limited water supplies. These units are equipped with diesel auxiliary engines and 500 gpm pumps. They carry 1,500 gallons of water and have one remote-control and one manual nozzle. Three of these trucks are stationed at each end of the Hanford Site.

A hazardous materials response vehicle is located in Station 2. This vehicle is equipped with many types of diking, plugging, and patching material. HM-91 is equipped for cleanup and overpacking. Protective clothing ranges from coveralls to fully encapsulated suits. Many information resources are available in the vehicle in the air-conditioned resource module.

One cascade truck, equipped for remote bottle filling from electric or diesel-driven motors, is kept in Station 94. This truck was designed on-site.

A heavy rescue squad truck is stationed at the 300 fire station. This vehicle carries equipment for cave-in, confined space, building collapse, and high angle rescues. A similarly-equipped trailer is located at Station 92 .

A mass casualty trailer is maintained at Station 91 for use across the site. This unit has large quantities of medical supplies on board, designed for an accident with multiple victims.

Hanford Fire Department staffing, training, and equipment is adequate.

c. Response Times and Access

An average response time of seven minutes from time of alarm with an additional three minutes to lay hose lines was provided by the Hanford Site Fire Department 
for the CWC. Fire Department response personnel carry master keys for most facilities and have access to forcible entry equipment. Fire Department response vehicles have access to all four sides of buildings at the CWC.

Hanford Fire Department response time and facility access is adequate.

\section{d. Fire Department Building Inspections}

General building fire inspections are scheduled to be conducted by operations personnel. Procedures are in place which indicate that operations personnel have been trained and certified to perform the operations identified in the procedure. Personnel are responsible for monthly visual inspections of fire extinguishers, a daily facility tour to identify off-normal conditions, monthly housekeeping inspection, and monthly visual inspection of PIVs and fire system pressures (water supply and supervisory pressures). The Hanford Fire Department Inspection group monitors the general building fire surveillance activities conducted by operations personnel.

The Hanford Fire Department, Fire Systems Testing and Maintenance Division is responsible for testing and maintenance of fire detection and suppression systems. Test procedures are documented as Facility Maintenance Support Services, Site-Wide Test Procedures. Hanford Fire Department test and maintenance activities consist of a weekly battery check or semiannual battery maintenance, a 120-day RFAR test, a 6-month smoke detector inspection, a 2-month alarm bell test, and a 4-month flow test or winter low air pressure supply test. Impairments and deficiencies are tracked in a handwritten log (Deficiency Log Book - Book 1) maintained by the Hanford Fire Department. Impairments and deficiencies are also logged and tracked on a data base. An Internal Memo, Impaired Fire Suppression Systems and General Information is submitted to the building administrator or manager on a monthly basis. The building administrator or manager is requested to provide status updates of impairments and deficiencies.

Westinghouse Hanford Company inspection, test, and maintenance activities generally meet the intent of NFPA 25 . A test procedure for the dry chemical systems at the LFMW and AMW Modules was not reviewed during the survey.

\subsection{Recovery Potential}

Recovery from a MFL scenario for the CWC Buildings and Modules evaluated in this report may require moderate cleanup and decontamination efforts within the area of fire origin and near the outside vicinity of the fire area. Recovery from a MFL-type fire may take approximately three to six months for exterior outside cleanup and potentially six months to nine months to complete internal building cleanup. 
Recovery from an MCFL scenario for the CWC building evaluated in this report may require minor decontamination and cleanup efforts, primarily in the immediate area of fire origin. Recovery from an MCFL fire incident may take approximately one to two months for exterior outside cleanup and potentially one to three months to complete internal building cleanup. For CWC Modules not provided with automatic protection, the MCFL scenario is equal to the MFL scenario referenced above.

\subsection{Potential for a Toxic. Biological, and/or Radiation Incident Due to a Fire}

A fire at the CWC complex may have a minor environmental impact due to unfiltered releases of combustion products containing radioactive isotopes or PCB combustion products. Estimations of representative mass flow releases from potential fires at Buildings $2401 \mathrm{~W}, 2402 \mathrm{~W}$ through WL, $2403 \mathrm{WA}$, WB, WC, and WD, the LFMW and AMW Modules, and the Mixed Waste Storage Pad are estimated in Appendix B of this report.

Buildings $2401 \mathrm{~W}$ and $2402 \mathrm{~W}$ through WL are each provided with a $15.24 \mathrm{~cm}(6-$

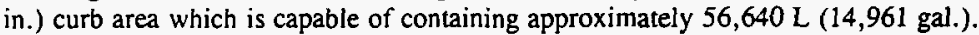
Buildings 2403 WA, WB, WC, and WD are each provided with four quadrants. The floor of each quadrant slopes toward the center of the quadrant to a small sump. Each quadrant in Buildings $2403 \mathrm{WA}, \mathrm{WB}$, and WC can contain approximately $94,530 \mathrm{~L}(24,975 \mathrm{gal}$.$) and in Building 2403 \mathrm{WD}$ can contain approximately 150,980 $\mathrm{L}(39,889 \mathrm{gal}$.). Based on a reduction of capacity for container storage, the containment areas provided for these buildings should be capable of containing the volume of fire-protection water from the sprinkler system over the minimum design area for a period of at least 20 minutes.

The Mixed Waste Storage Pad is also provided with a containment area which is capable of containing approximately $103,149 \mathrm{~L}(27,252 \mathrm{gal}$.$) . Based on a reduction$ of capacity for container storage, the Mixed Waste Storage Pad should be capable of containing water runoff from fire department hose streams for at least 20 minutes.

The LFMW and AMW Modules have limited containment capacity, and a fire at the modules which are not provided with an automatic dry chemical system will need to be suppressed by the fire department. The containment area provided for the modules will only contain a single fire hose at $9461 \mathrm{pm}(250 \mathrm{gpm})$ for approximately 3 minutes before overflowing.

\subsection{Emergency Planning}

The facility emergency plan is documented in Building Emergency Plan for the Central Waste Complex, WHC-IP-0263-CWC, Westinghouse Hanford Company, dated August 31,1993 . The facility emergency plan appears to meet, as a minimum, requirements identified in 29 CFR 1910.38, Employee Emergency Plans and Fire Prevention Plans. 
Fire Department Facility Pre-fire Plans are also available but are not carried on response vehicles. Response information is relayed to the responding vehicles from the Fire Department Central Station by radio. On-board computers and printers are provided for first line response vehicles; however, fire department personnel indicated that the system was not reliable. Response vehicles are supposed to receive prefire plan information through the on-board computer system from the CAD system described above in the Fire Protection Features section. A Hanford Fire Department representative indicated that the pre-fire plans are also available at the CWC in specific dry pipe sprinkler system valve houses or at Radio Fire Alarm Transmitter boxes. The pre-fire plans provided by the Hanford Fire Department are dated November 1989, January 1990, February 1990, November 1992, May 1993, September 1993, and January 1994. Since operations at the CWC buildings have not changed, the pre-fire plans provided for Buildings $2401 \mathrm{~W}, 2402 \mathrm{~W}$ through WL, and 2403 WA, WB, WC, and WD are still current. Pre-fire plans were not available for either the LFMW and AMW Modules or the Mixed Waste Storage Pad and the Waste Unloading and Storage Pad.

Additional pre-fire plans need to be developed for the LFMW and AMW Modules, the Mixed Waste Storage Pad, and the Waste Unloading and Storage Pad.

\subsection{Security and Safeguards}

Access to the 200 -West area is controlled by guard gates at the Yakima, Rattlesnake, and Wye barricades. The CWC is located within a fenced area. The fence is approximately $10 \mathrm{ft}$. high. The vehicle gates are maintained locked when the facility is not occupied. The south gate is normally maintained open when the CWC is occupied. The exterior doors to the buildings and modules are maintained locked when operations personnel are not present. The buildings are provided with panic hardware for exiting.

The current methods for securing the $\mathrm{CWC}$ do not adversely affect the buildings nor restrict fire department access.

\subsection{Natural Hazards}

Natural phenomenons are addressed in the Central Waste Complex Inrerim Safecy Basis and the Cenral Waste Complex Final Safety Analysis Report, Final Safety Analysis Document Upgrade documents.

Drum fire accidents caused by natural events such as earthquake or windstorm were judged as non-credible events as indicated in Appendix B of this report. 


\subsection{Exposure Fire Potential}

\section{a. Exposing Structure}

There are no buildings outside the fenced $\mathrm{CWC}$ area which create a fire exposure to Buildings $2401 \mathrm{~W}, 2402 \mathrm{~W}$ through WL, and $2403 \mathrm{WA}$, WB, WC, and WD, LFMW and AMW Modules, or the Mixed Waste Storage Pad.

b. Exposed Structure

Buildings $2401 \mathrm{~W}, 2402 \mathrm{~W}$ through WL, and $2403 \mathrm{WA}, \mathrm{WB}, \mathrm{WC}$, and WD are noncombustible, pre-engineered, steel structures. Reference Appendix A of this report for dimensions of structures and openings.

A review of Buildings $2401 \mathrm{~W}, 2402 \mathrm{~W}$ through WL, and $2403 \mathrm{WA}, \mathrm{WB}, \mathrm{WC}$, and WD against NFPA 80A requirements indicates that the buildings are sufficiently separated such that one structure does not cause a fire exposure to the other.

A potential fire at Buildings $2401 \mathrm{~W}, 2402 \mathrm{~W}$ through WL, and $2403 \mathrm{WA}$, WB, WC, and WD, LFMW and AMW Modules, or the Mixed Waste Storage Pad may result in releases of combustion products which may cause contamination at other structures.

\subsection{National Security Consequences}

Operations which can affect national security are not conducted at the CWC.

\subsection{CONCLUSION}

Based on the probability modeling conducted in Appendix B, MCFL and MFL incidents were estimated to be unlikely events for the CWC buildings evaluated in this report.

For both MCFL and MFL incidents, the consequential quantities of plutonium species which could potentially be released outside the CWC Buildings evaluated were estimated to be fairly low. Risk estimations are presented in Section 5.0 of Appendix B.

As presently configured, the CWC provides an acceptable level of life safety for occupants. There are no essential safety class systems, and no DOE vital programs will suffer unacceptable delays. 


\subsection{RECOMMENDATIONS AND SUGGESTED IMPROVEMENTS}

Recommendations relate to improvements associated with meeting UBC, UFC, and NFPA requirements. Suggested improvements relate to good fire protection engineering practices which should be considered to improve the overall fire safety level of the facility.

\section{Recommendations:}

95-1 Provide manual exterior exhaust fan shutdown switches for Buildings 2403 WA, WB, WC, and WD to provide a means for the fire department to manually control the exhaust fans (UFC) (Reference Appendix $D$ for WHC Supporting Information).

95-2 Provide additional permanently installed heater capacity or improve valve house insulation so that portable heaters are not needed in sprinkler valve houses (NFPA 13) (Reference Appendix D for WHC Supporting Information).

95-3 Review the capacity of the dry sprinkler piping served by each auxiliary drain to determine if the pipe capacity is greater than $18.9 \mathrm{~L}$ (5 gal.). If the capacity of the piping served by an auxiliary drain is greater than $18.9 \mathrm{~L}$ (5-gal.), two $2.5-\mathrm{cm}(1-\mathrm{in}$.) valves and one $5.1-\mathrm{cm}$ by $30.5-\mathrm{cm}(2-\mathrm{in}$. by 12 -in.) condensate nipple or equivalent need to be provided for the auxiliary drain to comply with NFPA 13 requirements (Reference Appendix D for WHC Supporting Information).

95-4 Alter sprinkler systems or water supply if minimum density for Ordinary Hazard, Group 1 and a $1,892 \mathrm{lpm}(500 \mathrm{gpm})$ hose stream allowance is to be achieved for Buildings $2401 \mathrm{~W}$ and $2402 \mathrm{~W}$ through $\mathrm{WL}$, as required by DOE $6430.1 \mathrm{~A}$ (Reference Appendix D for WHC Supporting Information). 


\section{APPENDIX A}

\section{SITE LAYOUT} DRAWINGS

\begin{tabular}{|l|c|}
\hline \multicolumn{1}{|c|}{ Drawing Number } & Revision \\
\hline FHA-CWC-A & 0 \\
FHA-CWC-S & 0 \\
FHA-2401 W & 0 \\
FHA-2402 & 0 \\
FHA-2402-WH & 0 \\
FHA-2402-W & 0 \\
FHA-2403-WA & 0 \\
FHA-2403-WB & 0 \\
FHA-2403-WC & 0 \\
FHA-2403-WD & 0 \\
FHA-WASTEPAD & 0 \\
FHA-CONT1 & 0 \\
FHA-CONT2 & 0 \\
FHA-CONT3 & 0 \\
FHA-CONT4 & 0 \\
FHA-CONT5 & 0 \\
FHA-CONT6 & 0 \\
FHA-CONT7 & 0 \\
FHA-CONT8 & 0 \\
\hline
\end{tabular}


WHC-SD-WM-FHA-008, Rev. 0

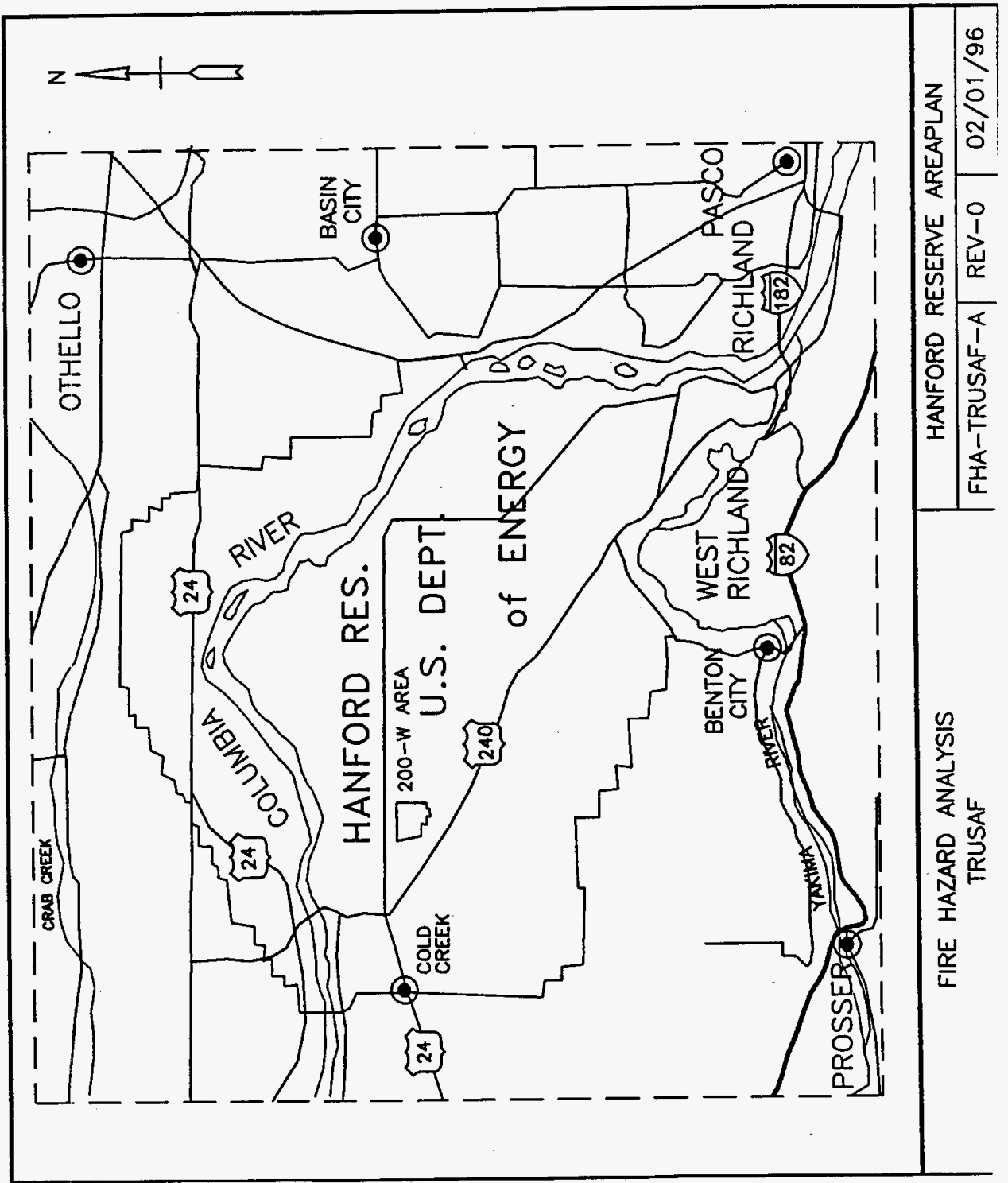




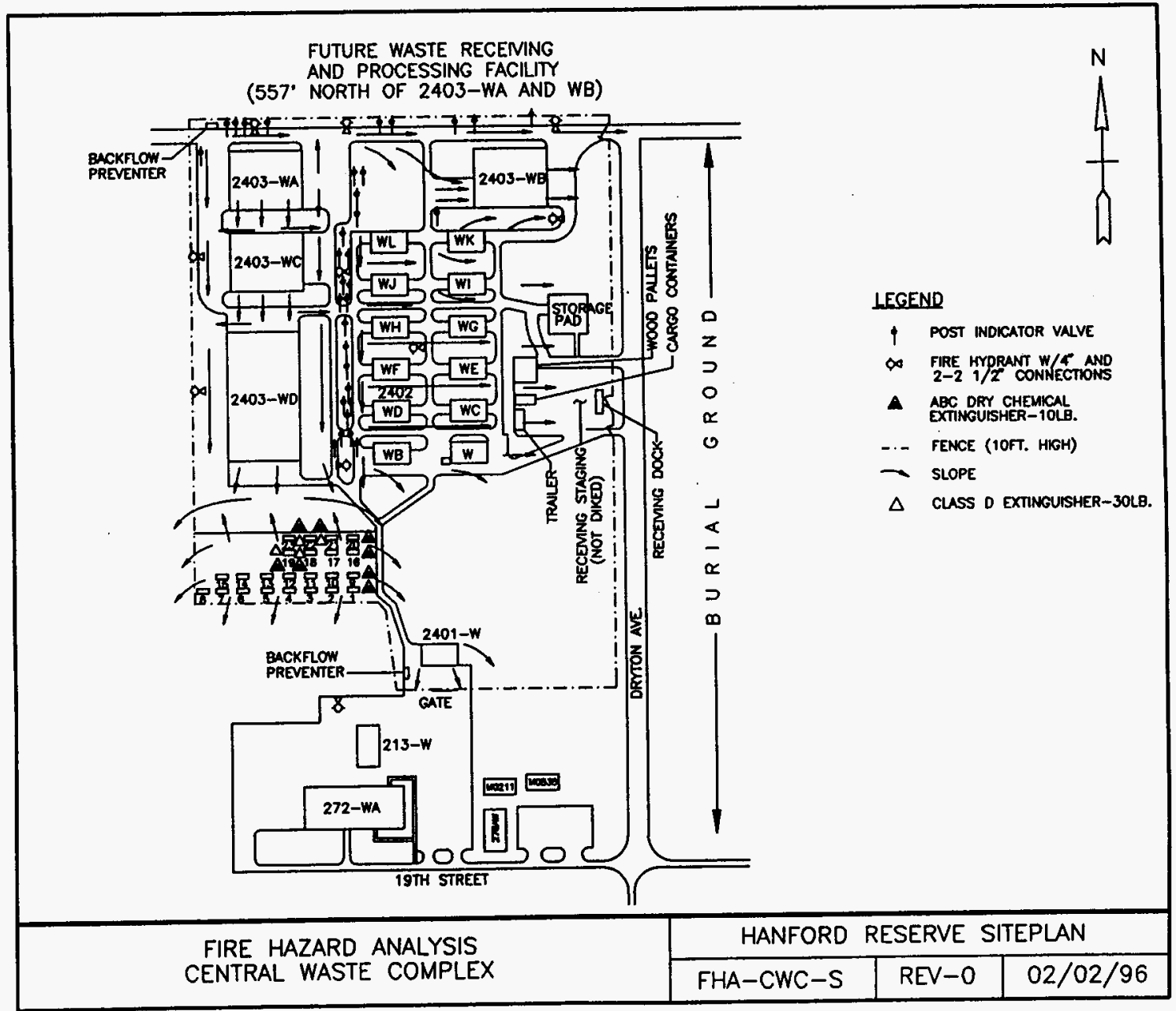



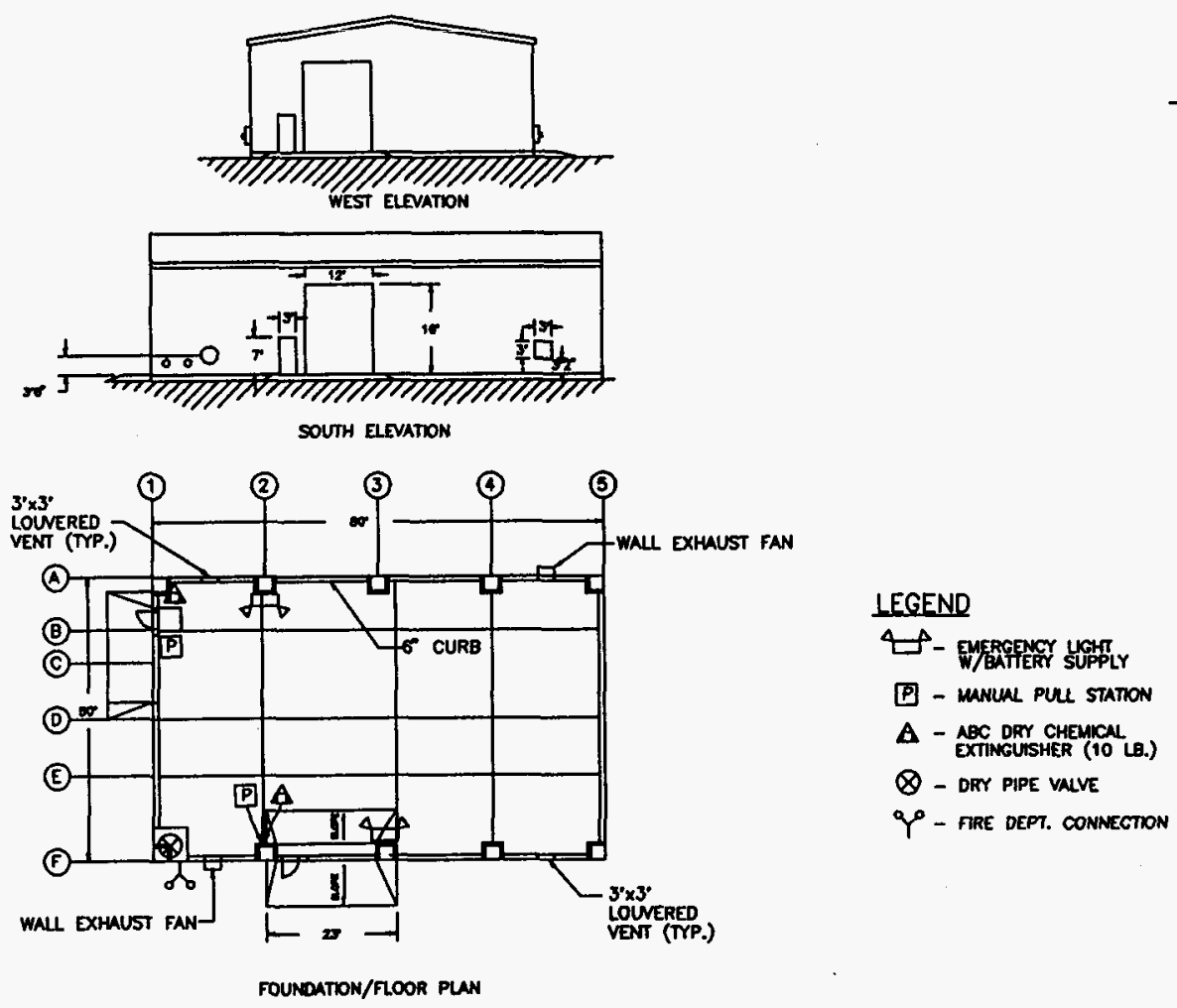


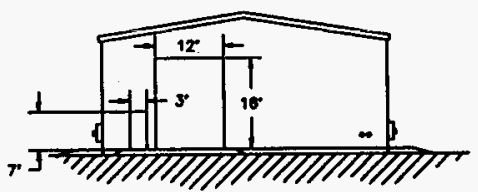

WEST ELEVATION
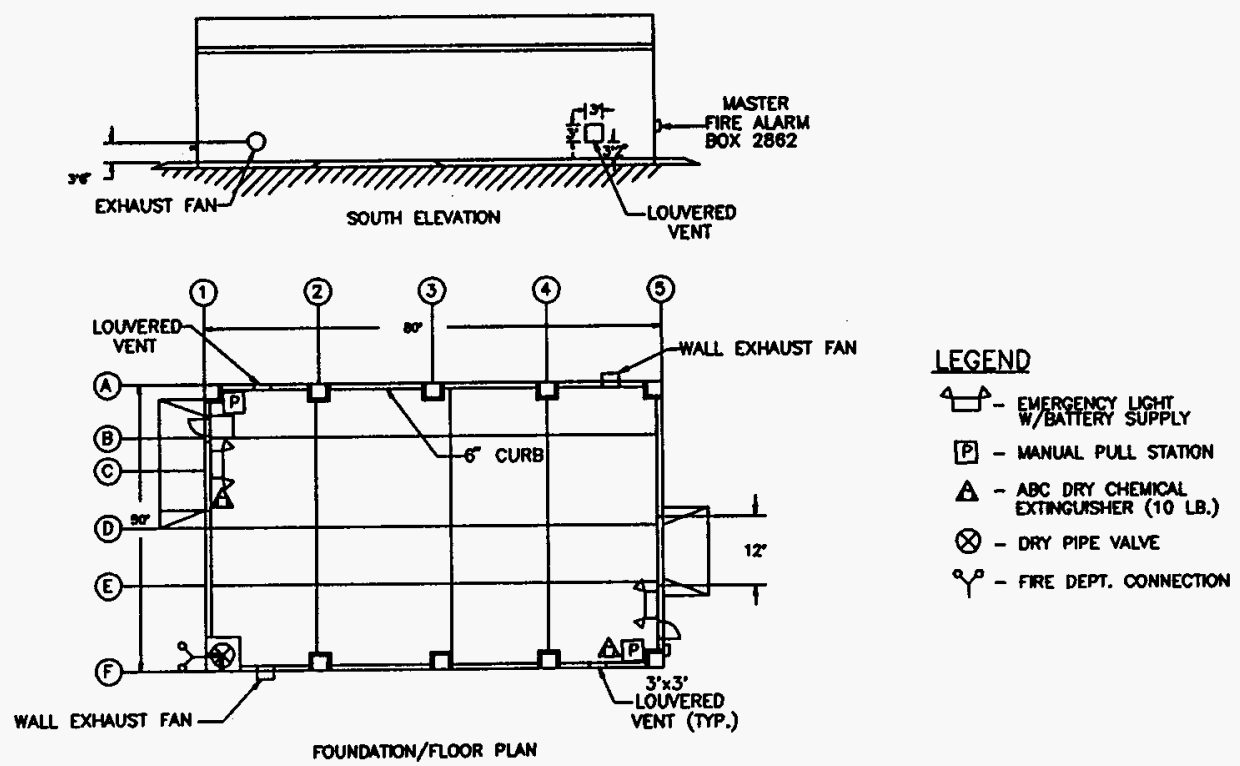

\begin{tabular}{ll|l|l}
\hline FHA-2402 & REV-0 & $02 / 02 / 96$
\end{tabular}




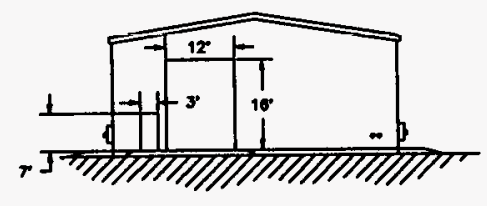

WEST ELEVATIOK
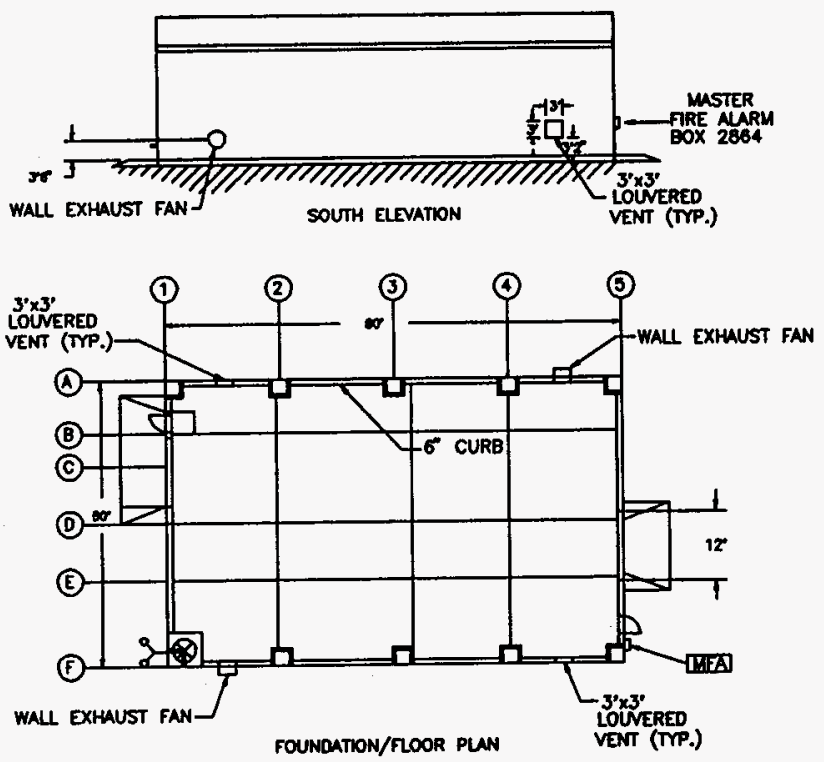

LEGEND

45 - EMERGENCY LEHT

[ - ManUN PULL STATION

A - ABC DPF CHEMICN

Q - DRY PIPE VALVE

QP - TRE DEPT. CONNECTION

[LIFX - MASTER FIRE NLARM BOX 

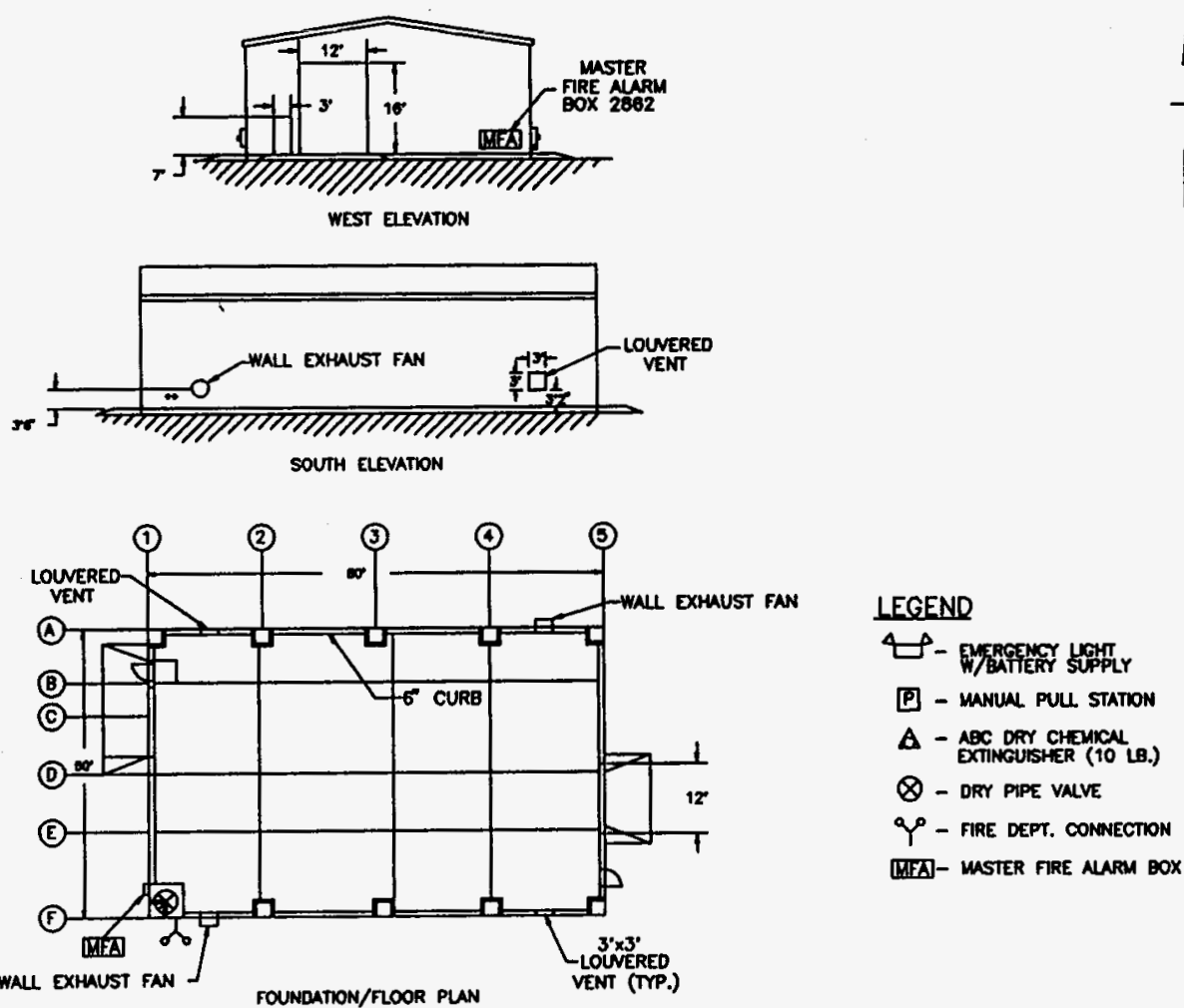


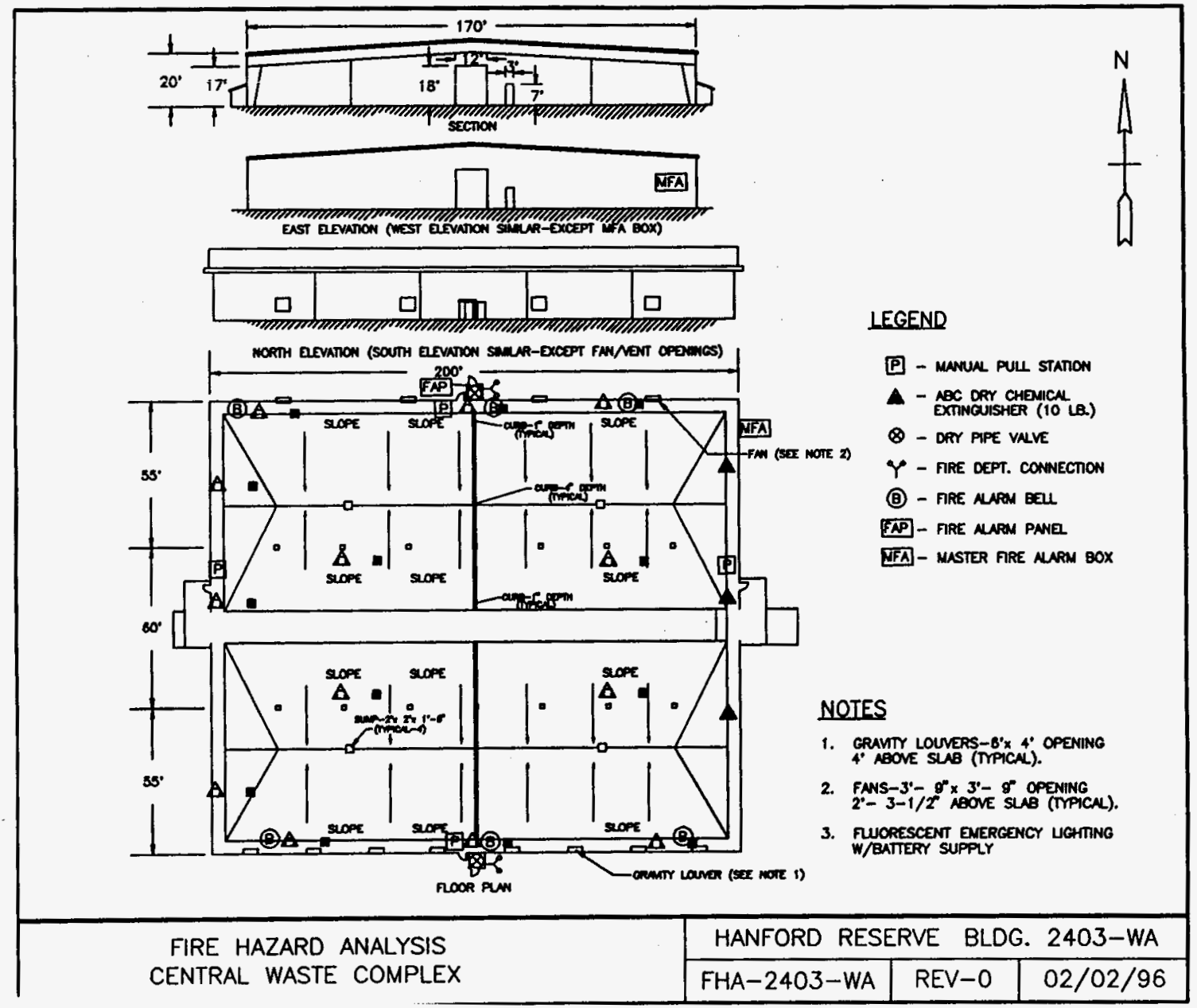




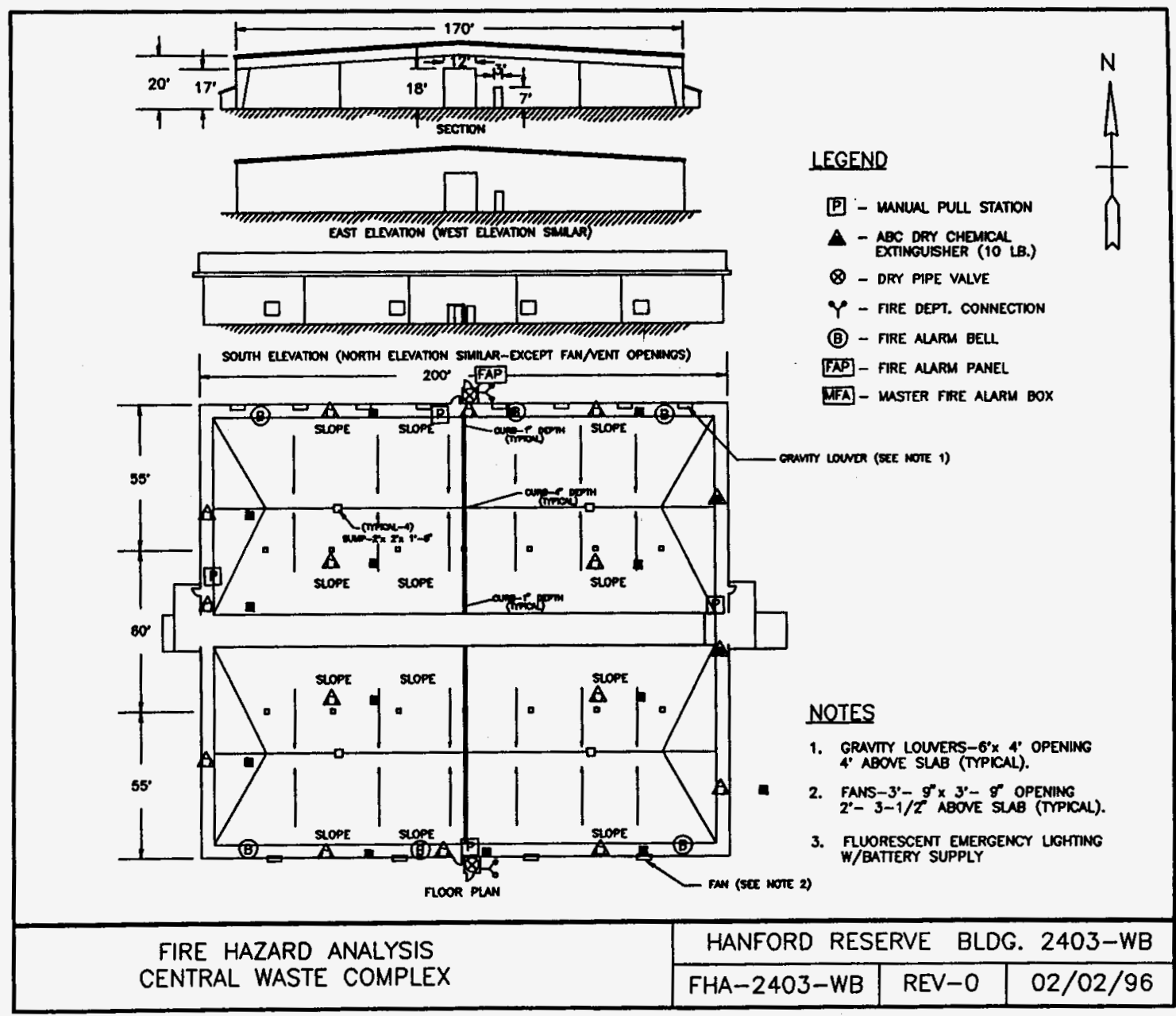




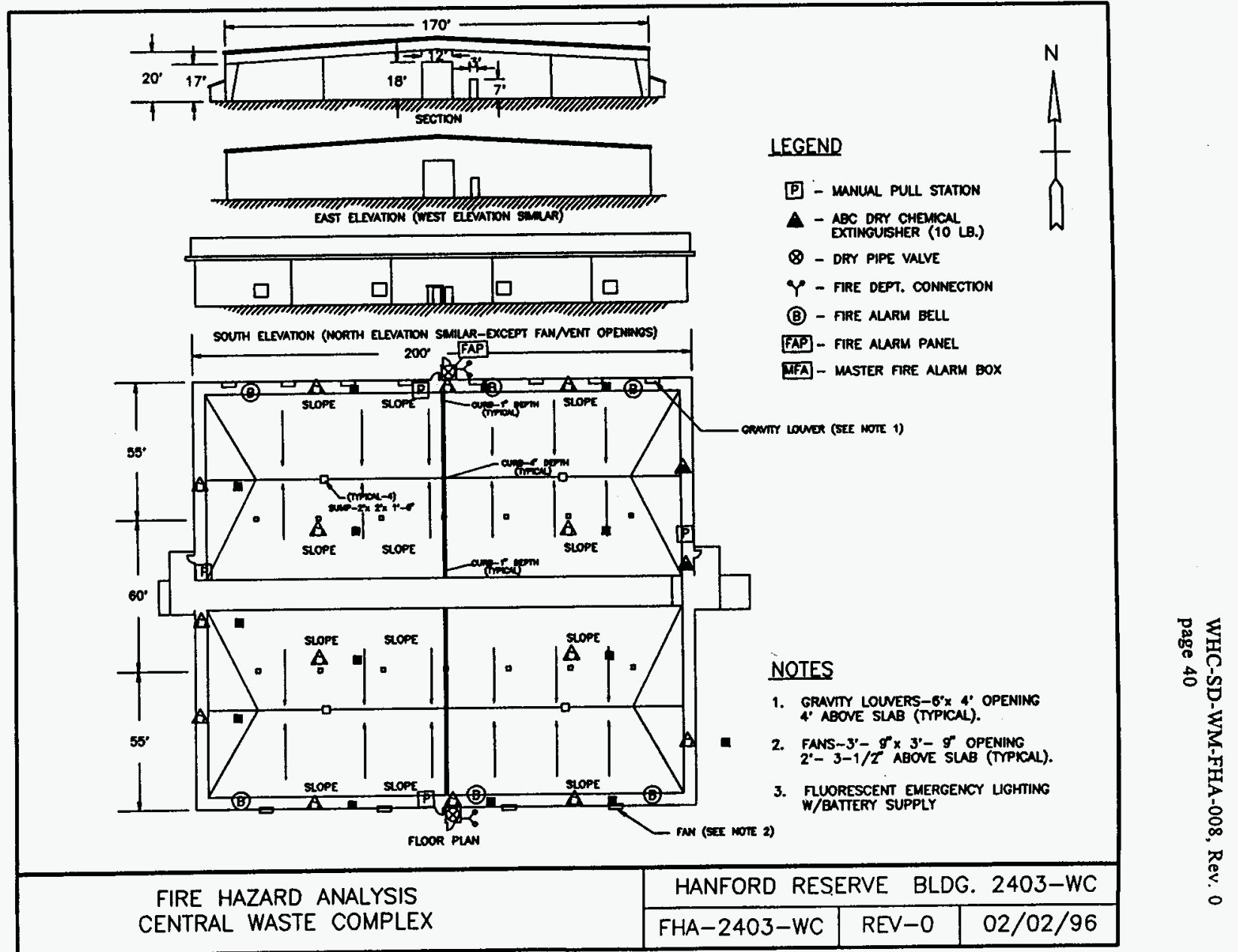




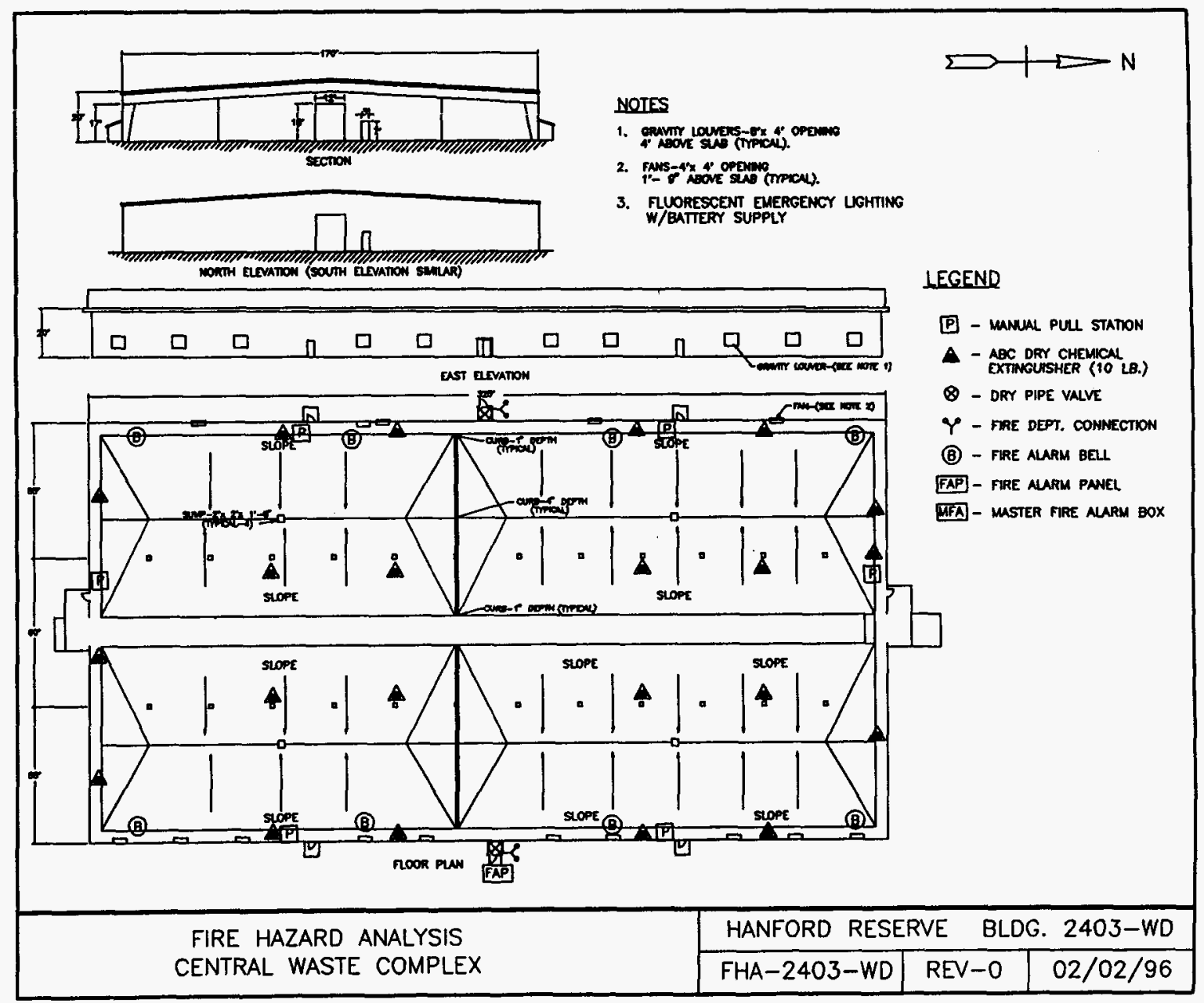




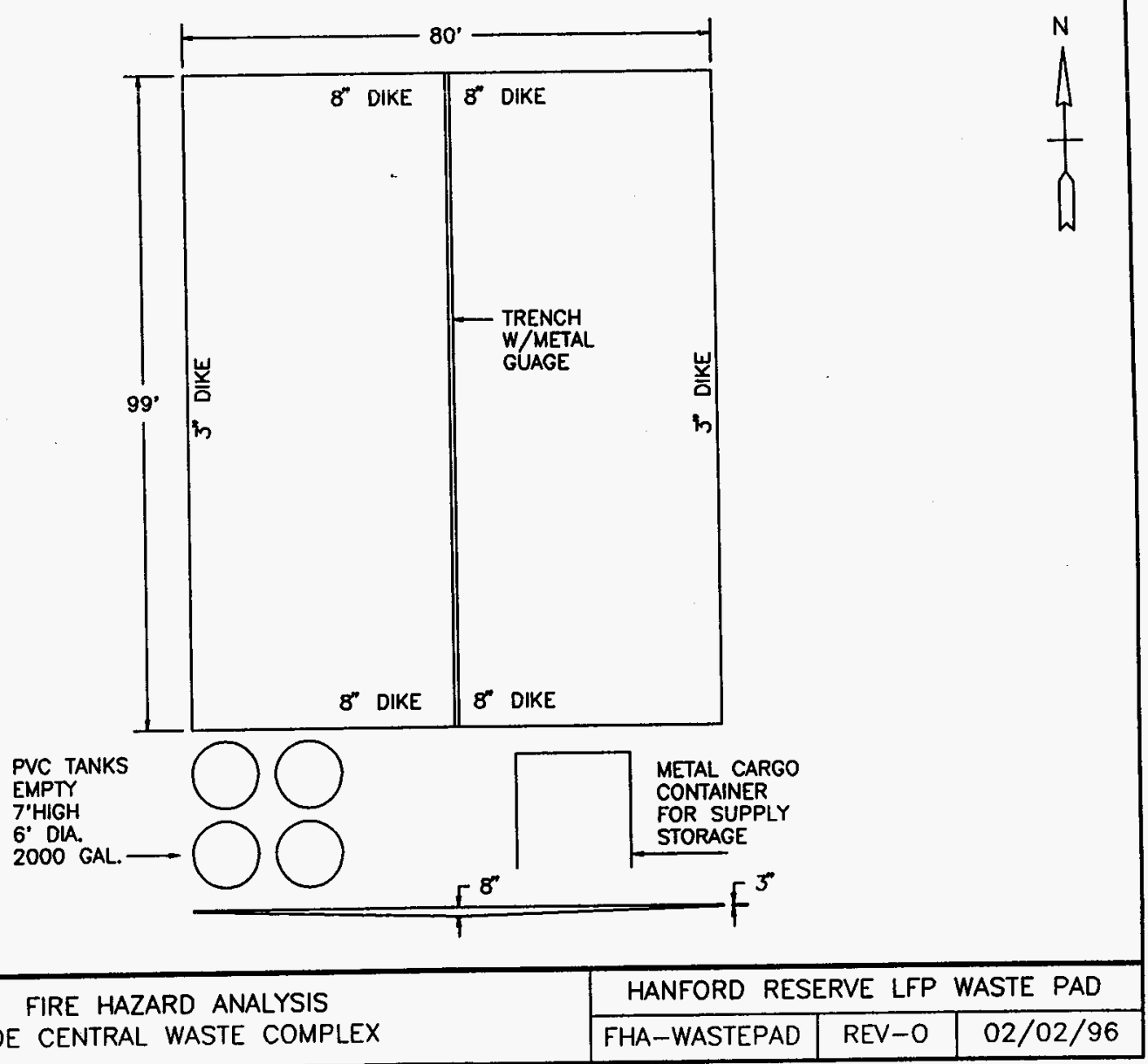


WHC-SD-WM-FHA-008, Rev. 0

page 43
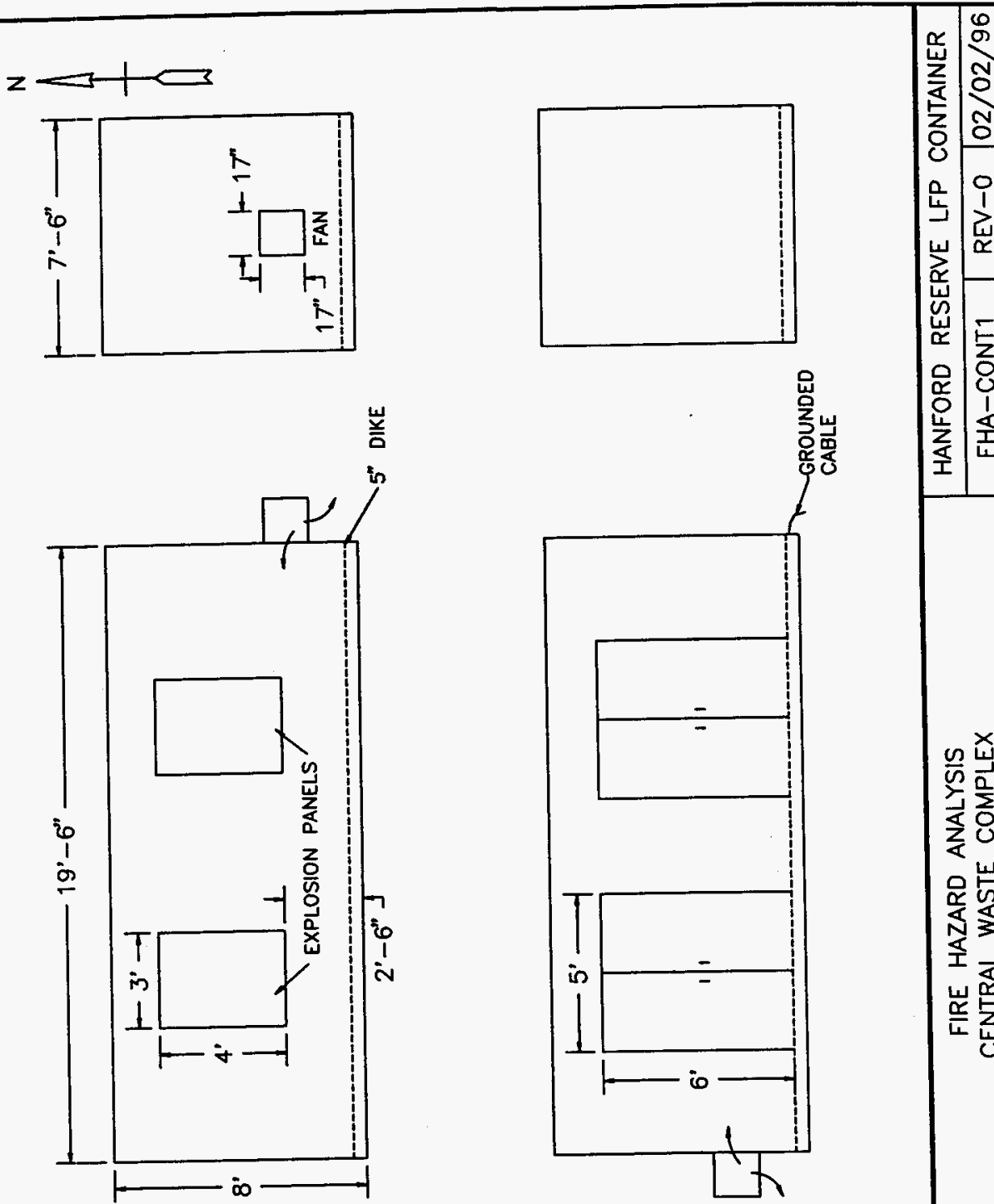

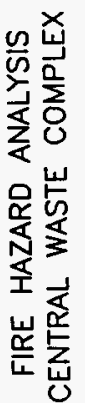




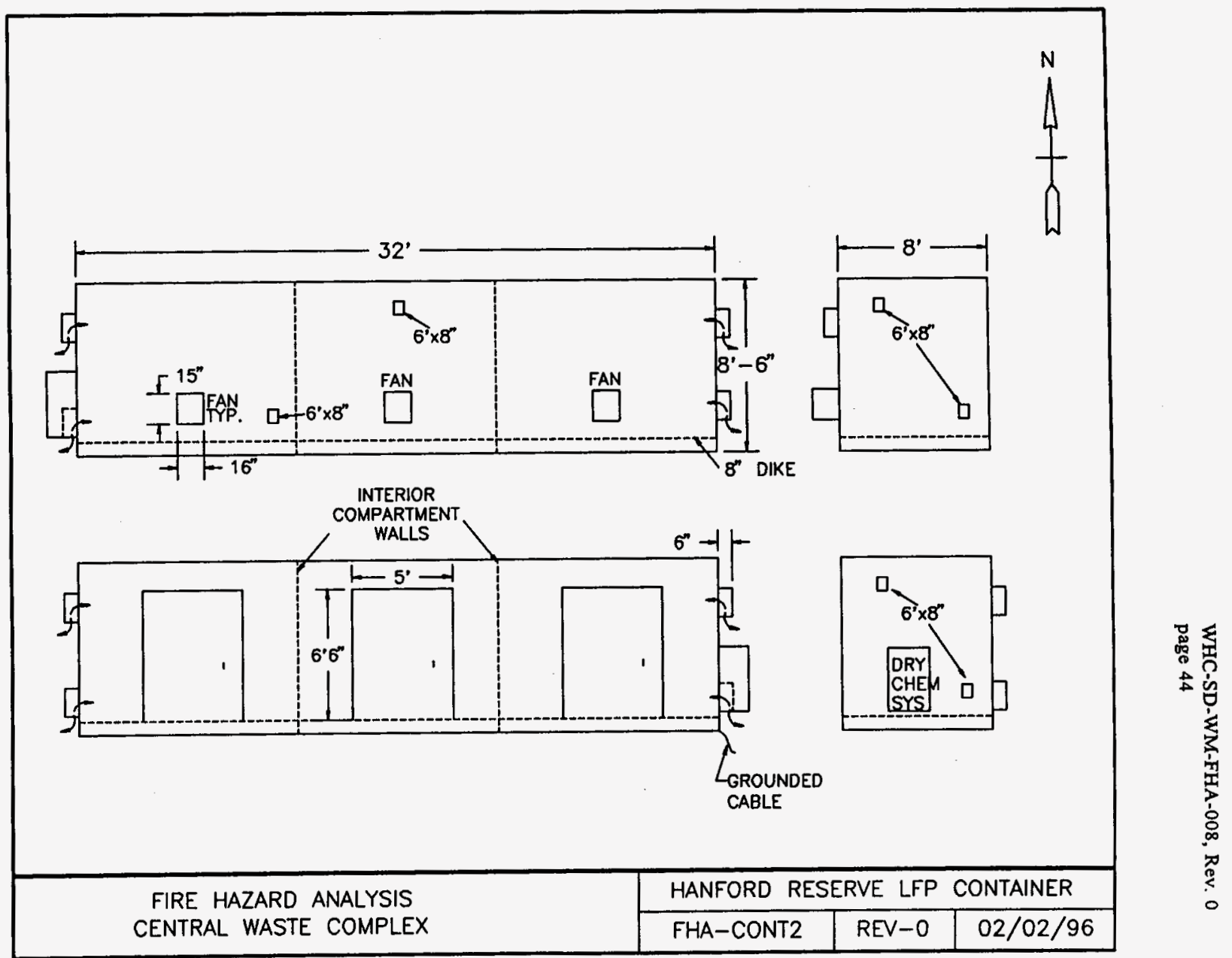




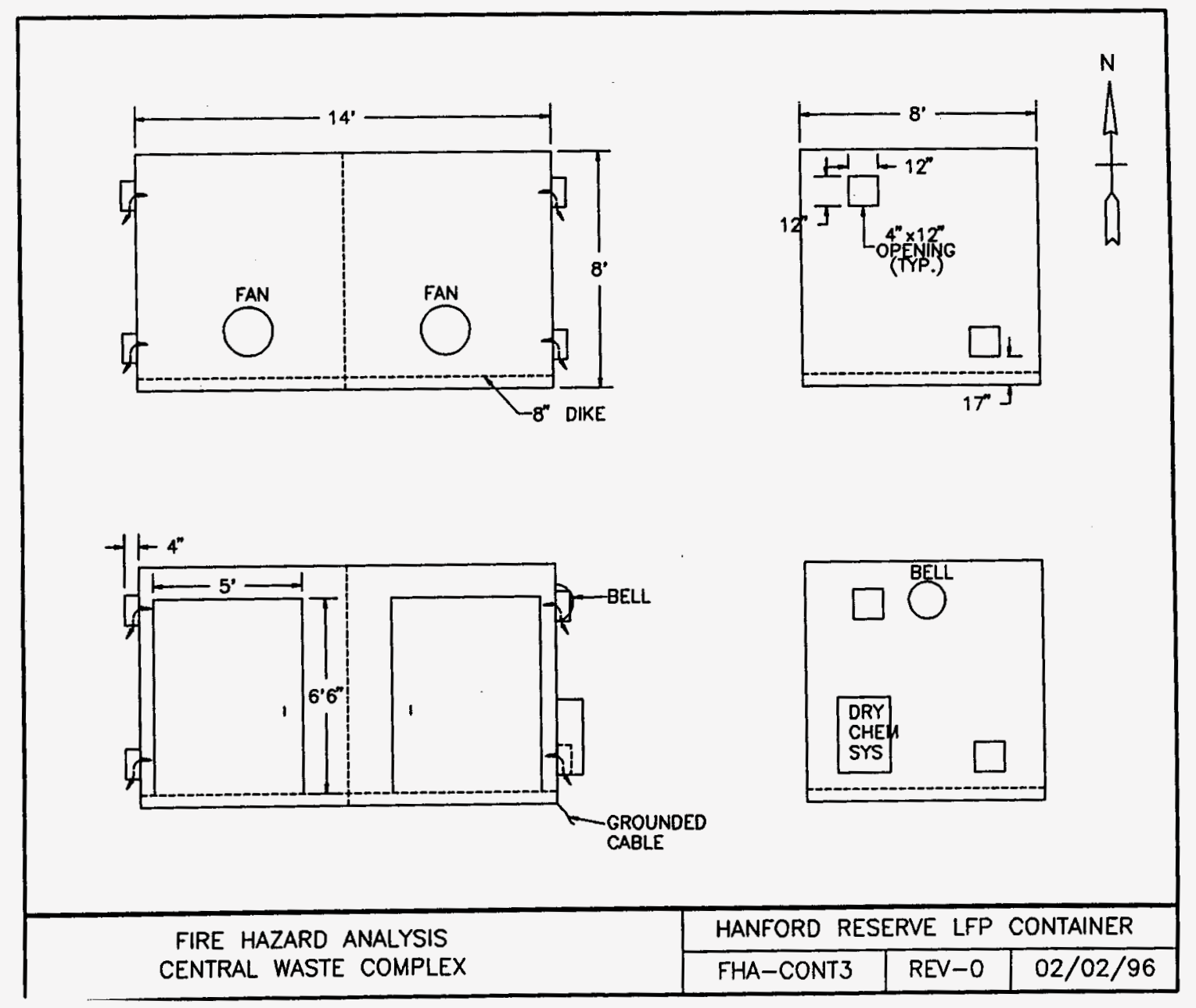




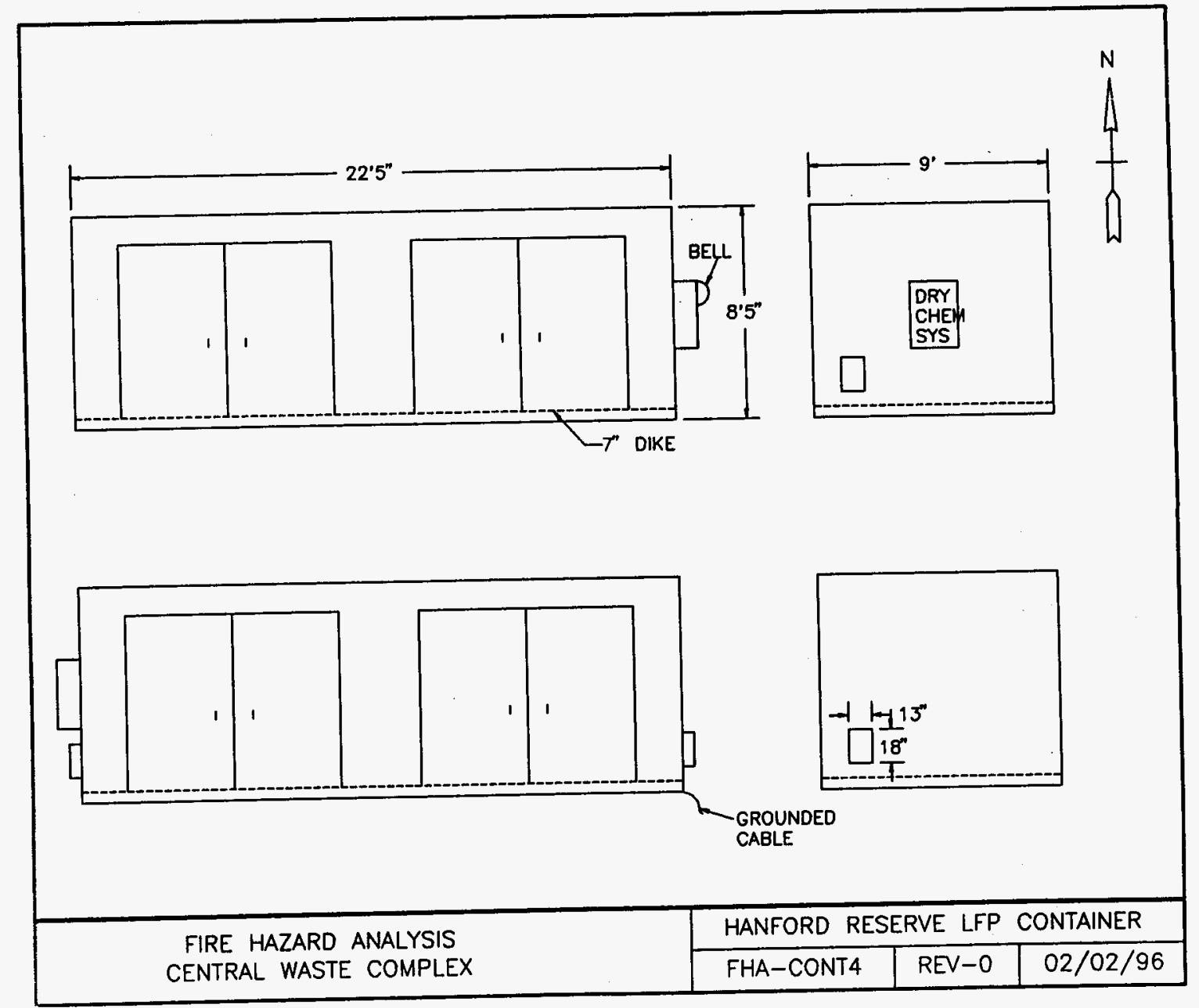




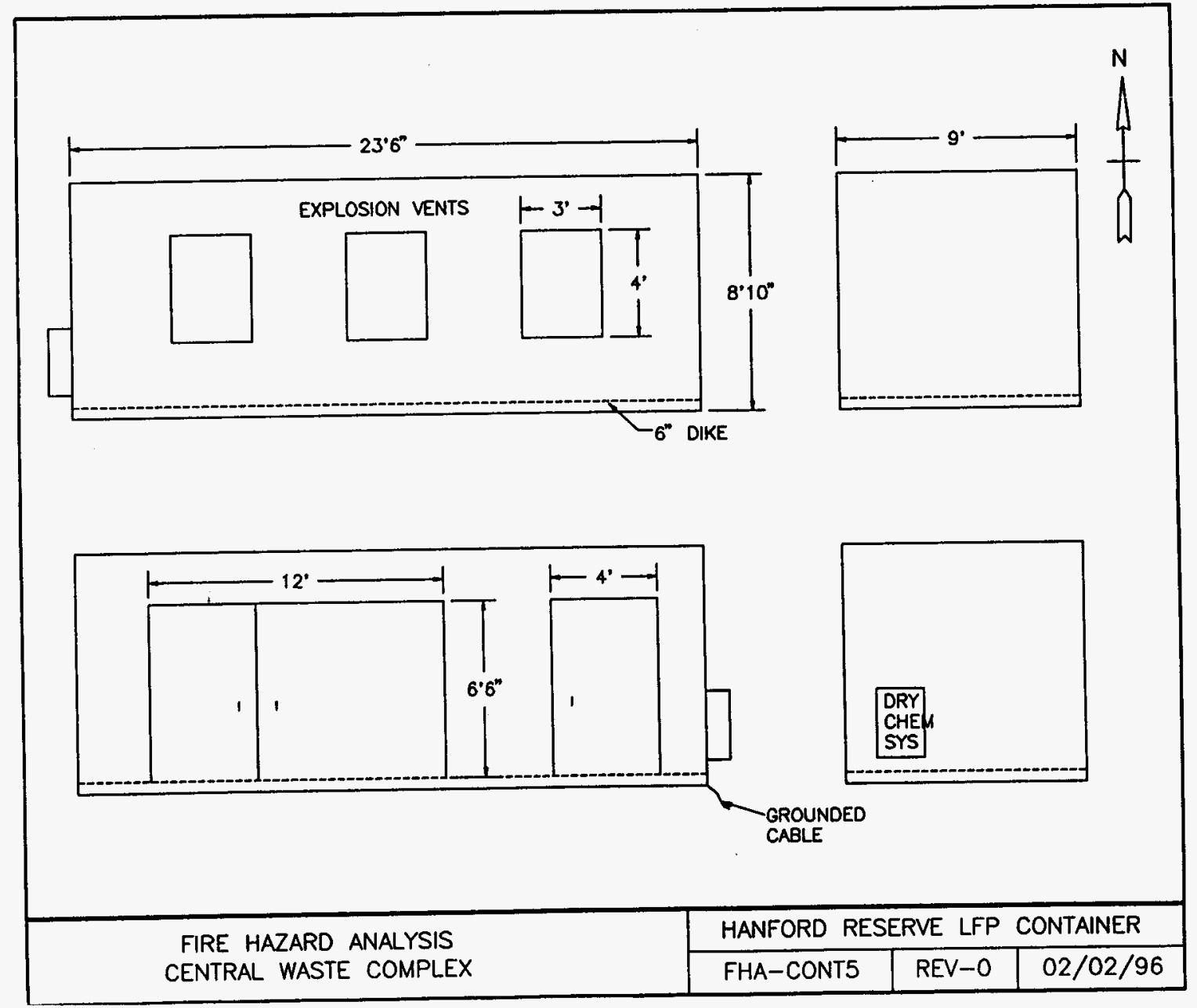




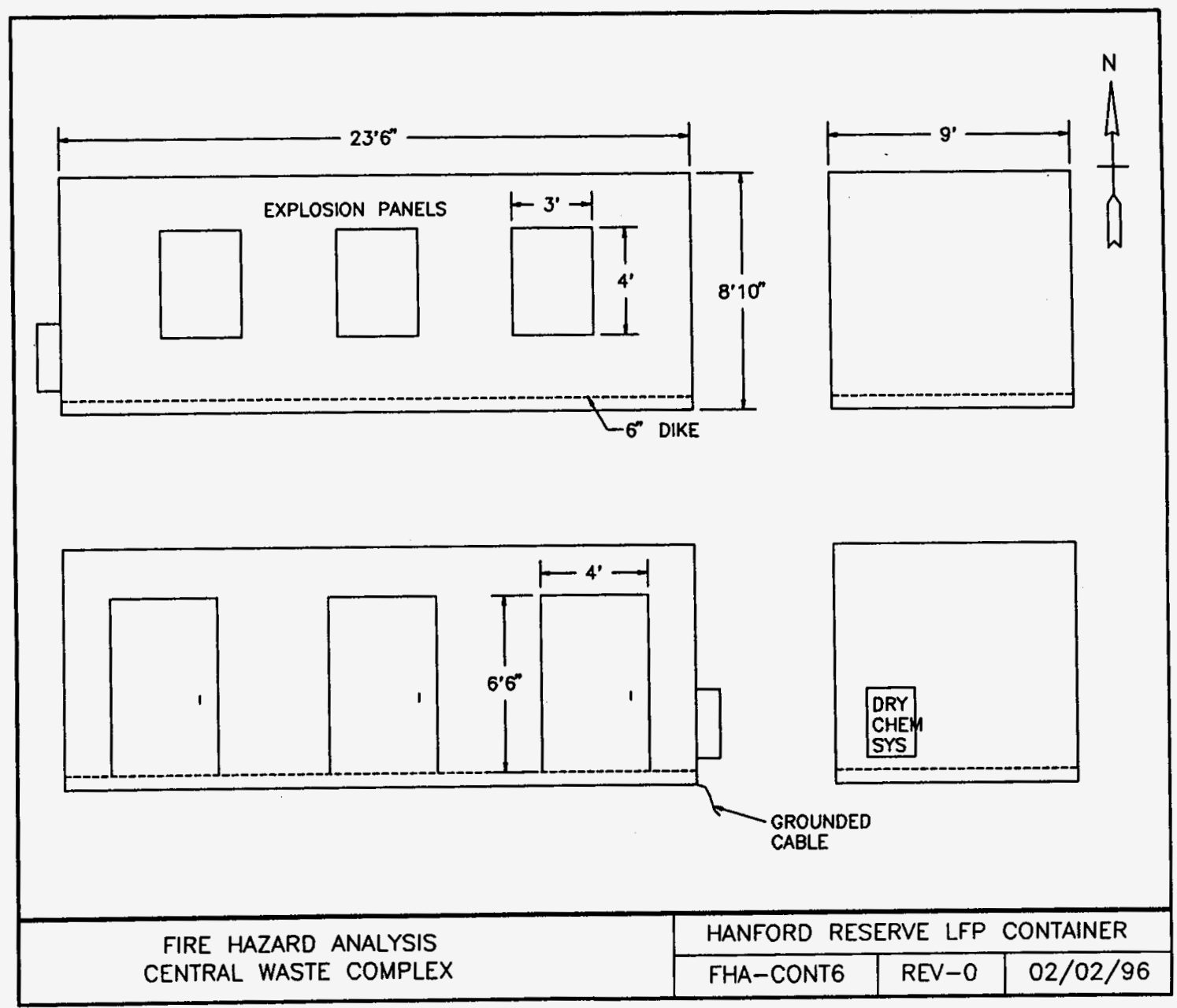




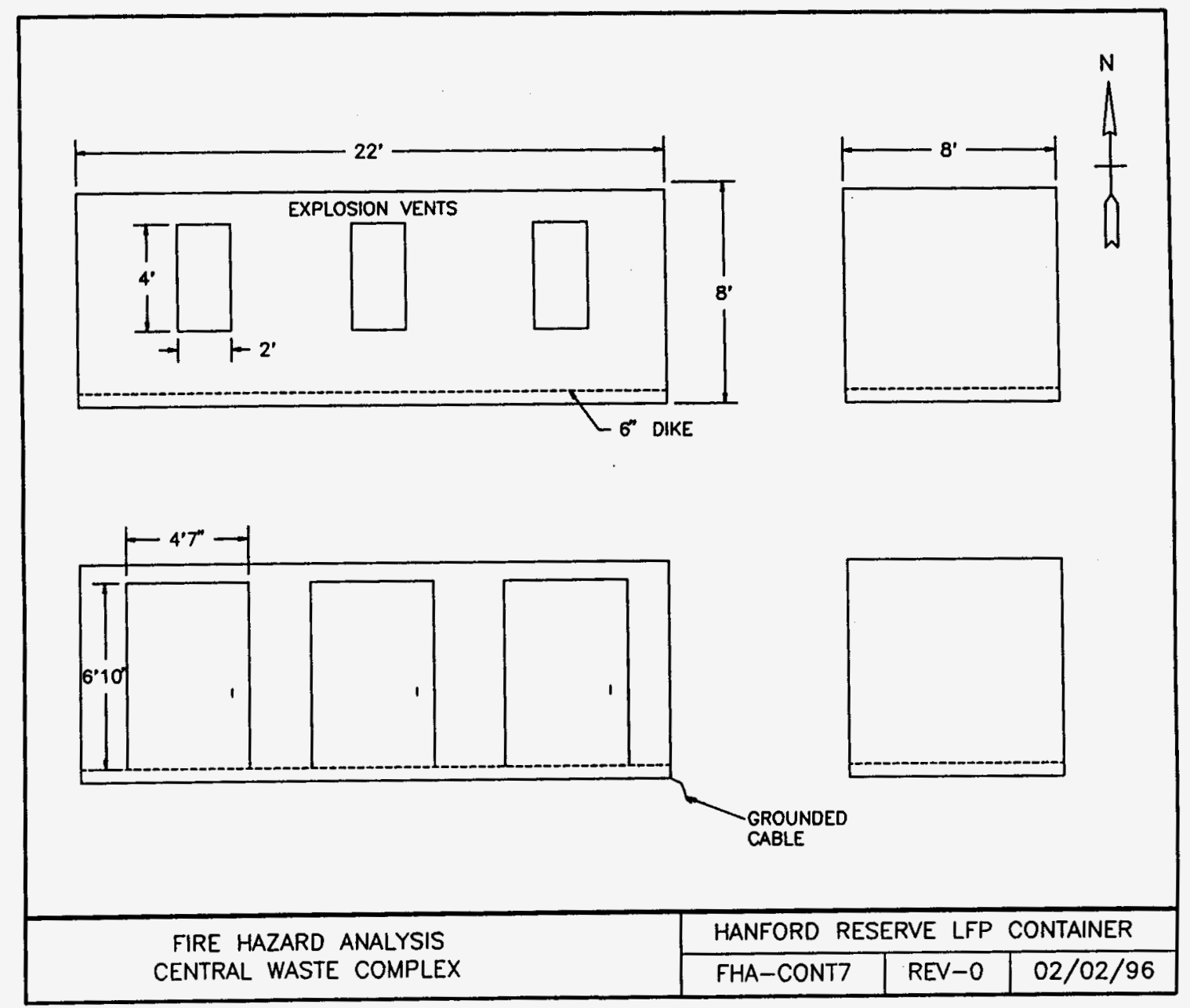


WHC-SD-WM-FHA-008, Rev. 0 page 50
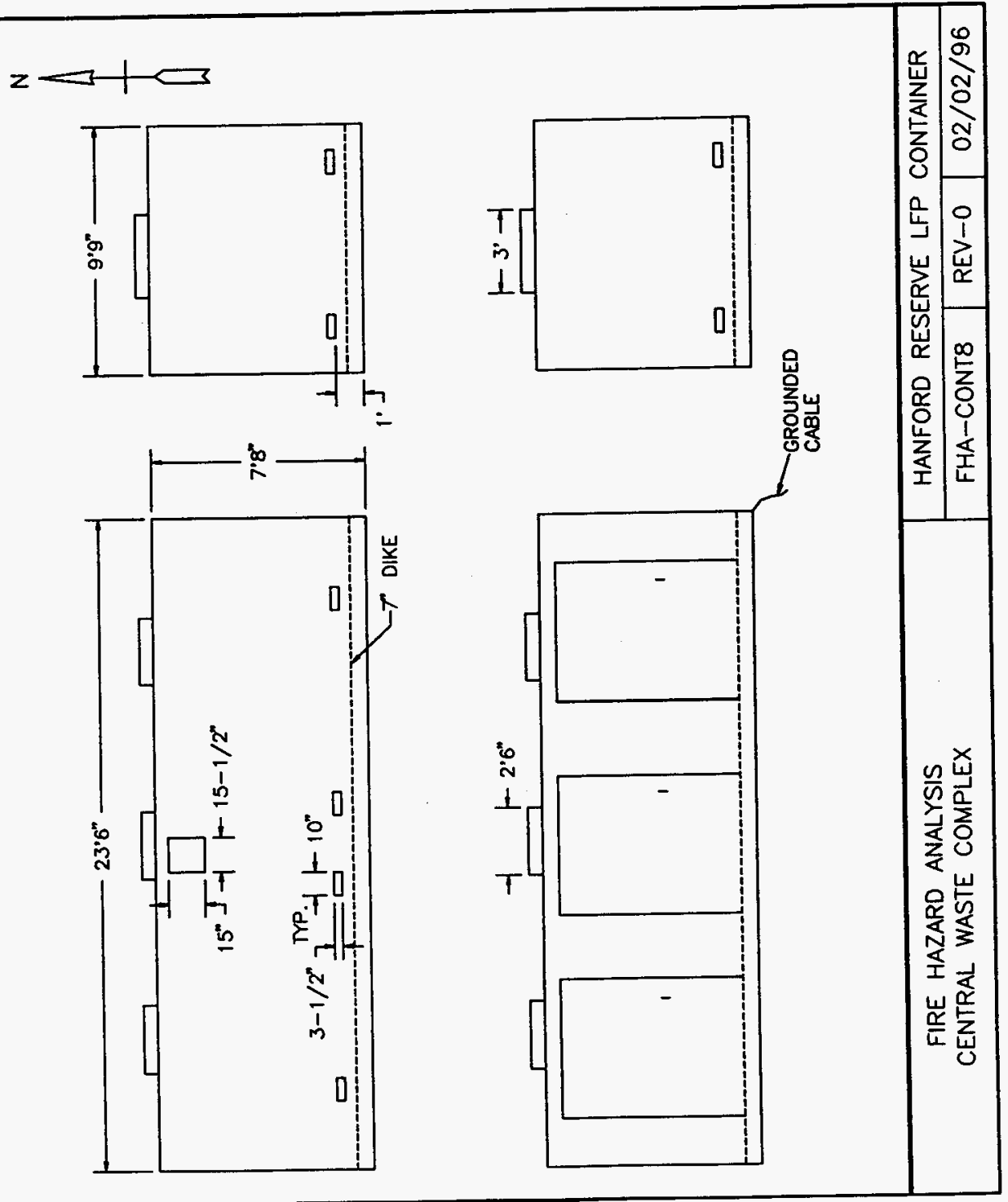
WHC-SD-WM-FHA-008, Rev. 0 page 51

\section{APPENDIX B}

\section{CENTRAL WASTE COMPLEX}

\section{FIRE RISK ASSESSMENT}


WHC-SD-WM-FHA-008, Rev. 0 page 52

APPENDIX B

CENTRAL WASTE COMPLEX

FIRE RISK ASSESSMENT

\section{TABLE OF CONTENTS}

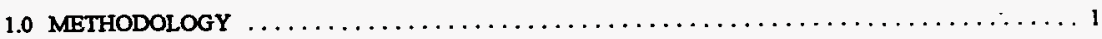

2.0 HAZARD IDENTIFICATION \& RISK SCREENING $\ldots \ldots \ldots \ldots \ldots \ldots \ldots$

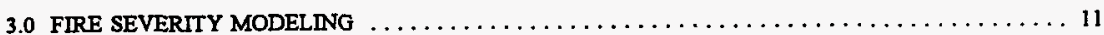

3.1 Fire Propagation Phases and Heat Release Rates $\ldots \ldots \ldots \ldots \ldots \ldots \ldots \ldots$

3.2 FPEtools Fire Modeling Output $\ldots \ldots \ldots \ldots \ldots \ldots \ldots \ldots \ldots \ldots \ldots \ldots$

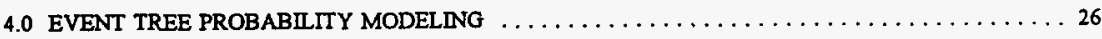

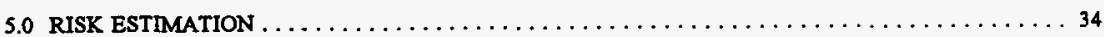

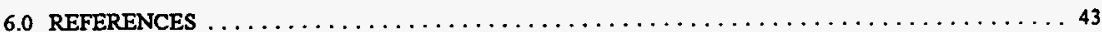


WHC-SD-WM-FHA-008, Rev. 0 page 53

\subsection{METHODOLOGY}

HSB Profeasional Loss Control applied quantitative risk assessment for supporting the Central Waste Complex (CWC) Fire Hazard Analysis (FHA). Risk assessment steps included:

- Definition of Risk Assessment Focus

- Hazard Identification \& Risk Screening

- Fire Severity Modeling

- Event Tree Probsbility Modeling

- Risk Estimation

\section{Risk Assessment Focus}

The primary focus of the FHA risk assessment support information was to provide quantification of:

- Radioactive species within fire combustion products which potentially could be released outside CWC solid waste storage buildings during a fire.

- The probability of occurrence for the following defined exposure levels:

- Maximum Credible Fire Loss (MCFL)

- Maximum Foreseeable Loss (MFL)

- Maximum Possible Fire Loss (MPFL)

This risk assessment support was provided for:

- Representative Small CWC Buildings, 2401 - 2402 W - WL

- Representative Moderate Size CWC Buildings, 2403 WA, WB, WC

- Large CWC Building, 2403 WD

- $\quad$ cwc Outside Storage Pad

- LFMW Storage Module 20 or 21 , which represented the bounding risk level for the CWC LFMW Storage Modules

Hezand Idemification \& Risk Sereening

Building walk-down surveys, design and procedures reviews, evaluation of storage inventory data sheets and reviews of previous hazard and safety reports were conducted to evaluate fire-related exposures and existing protection levels.

The material properties and fire hazards of the contents stored inside a representative sampling of storage drums based on review of inventory data records were evaluated. The material inventory, $\%$ composition, 
heats of combustion, and potential mass burning rates were quantified in order to establish a credible upper boundary heat release rate profile for input into the fire severity modeling.

The contributing factors which could lesd to an accidental drum failure, ignition of the drum's contents, and sustained burning were identified. In section 2.0 of this appendix, Fault Tree Analysis (FTA) was used to assess and screen selected accident events and to estimate the potential frequency of an initiating drum fire.

Fine Severify Modeling

The 1995 fire tests performed to evaluate potential fire propagation related to palletized storage of solid waste in drums [1] was used to support the development of fire stages and to estimate fire heat release rates.

FPEtools, version 3.2, a computerized fure model developed by the National Institute of Standards and Technology (NIST) [2] was utilized to estimate fire temperatures inside buildings and to support engineering judgements concerning the potential mass release rates of radioactive species outside of CWC buildings during a fire.

\section{Event Tree Probability Modeling}

Event Tree Analysis (ETA) was applied in the estimation of the probabilities of occurrence for the MCFL, PML, and MPFL fire exposure ievels. Where needed, fault trees were developed to support certain event probabilities such as fire detection and sprinkler system suppression success. The following event trees were developed:

- $\quad$ ETA-1: Representative of CWC Buildings, Palletized Solid Waste Drum Storage

- ETA-2: LFMW Storage Module 20 ar 21, which represented the bounding risk level for CWC LFMW Storage Modules

- $\quad$ CWC Storage Pad

Note: Event and fault trees for CWC Storage Pad are located in the CWCRAS Document.

\section{Risk Estimation}

The annualized probability of MCFL, MFL, and MPFL fire exposure levels versus the potential mass of PU species which potentially could be released outside a CWC bullding during a fire was estimated and is presented in section 5.0 of this Appendix. 
WHC-SD-WM-FHA-008, Rev. 0 page 55

\section{Acrongme and Abbreviations}

CWCRAS: A separate document, CWC Fire Hazard Analysis and Risk Assessment Support Information, provides additional data and modeling documentation. The acronym CWCRAS (CWC Risk Assessment Support) will be used when referring to this document.

POC:

Products of Combustion from the Fire.

EV;

Equivalent Vent.

PU/PE

Plutonium and/or plutonium equivalent materials (i.e., various radioactive isotopes). 


\subsection{HAZARD IDENTIFICATION \& RISK SCREENING}

\section{Fine Hazard Identification}

Fire hazard identification focus was placed on reviewing and ranking drum storage inventories in terms of heat release rate potential. The goal was to establish a credible heat release profile for an initiating drum fire exposure potential.

The CWC Building storage inventory data base was sorted according to types of materials. 421 drums were identified as containing $50-100 \%$ fill of plastic/polyurethane type materials.

$\begin{array}{lr} & \begin{array}{r}\text { Number of } \\ \text { drums with } \\ 50 \% \text { or } \\ \text { greater fill }\end{array} \\ & \begin{array}{r}\text { by volume. } \\ \text { Plastic / Polyurethane }\end{array} \\ \text { Rubber } & 421 \\ \text { Paper / Cardboard } & 20 \\ \text { Cloth / Rags / Nylon } & 59 \\ \text { Wood } & 137 \\ \text { Chemicals } & 48 \\ \text { Paint } & 7 \\ \text { Oils } & 18 \\ \text { (primarily contaminated solids/absorbed) } & 506 \\ \text { Liquids } & \\ \text { (primarily small, isolated quantities, absorbed/grouted) } & \end{array}$

Solid Waste Storage Record data sheets were requested for selected drums containing plastics and liquids (e.g., solvents in LFMW Storage Modules) for use in estimating the \% compositions and drum loading. Selected inventory data is located in the CWCRAS document.

Based on engineering examination and some preliminary fire modeling concerning an initiating fire scenario, the storage of mixed plastic materials, at or above a $50 \%$ by volume drum fill, represented an upper boundary fire heat release rate exposure for $\mathrm{CWC}$ buildings storing solid waste in drums.

\section{Risk Sereening}

Fault trees were constructed to identify contributing drum fire accident factors and to allow frequency estimation. Contributing drum fire accident events included:

- $\quad$ Fire Caused by Drum Handling Accident Involving a Forklift - Drum Collision

- Drum Fire Caused by Abnormal Reaction Inside Drum 
WHC-SD-WM-FHA-008, Rev. 0 page 57

- Combustible Material Fire Exposure to Storage Drums Inside Building

Concerning a delivery truck accident - drum collision:

It is possible that a delivery truck collision accident could initially fail more than one drum. However, as indicated in Fault Tree DN-D, the annualized frequency of this type of accident exposure was estimated at 7.44E-07 accidents/year which was considered a non-eredible event that did not warrant additional multidrum fire modeling efforts. Also drum fire accidents inside the building caused by natural events such as earthquake or windstorm were judged as non-eredible events.

The estimated "aggregate" accident event frequency which could lead to the initial failure of one drum and contents ignition was calculated at $1.27 \mathrm{E}-04$, which is considered a credible event. The initiating accident fault trees are provided in this section. 


\section{Applicable to CWC Site}

INITIATING DRUM FIRE EXPOSURE ESTIMATED FREQUENCY PER YEAR

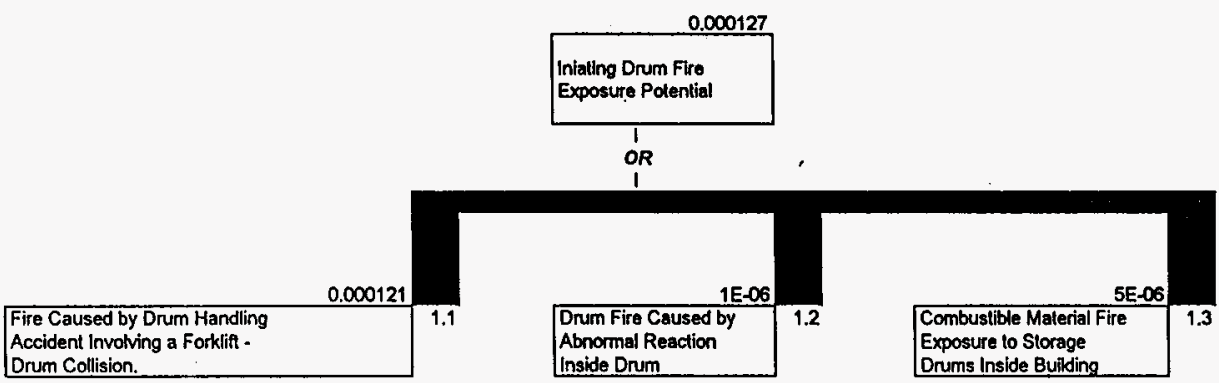

Fault

I.D. Probability Selection Basis

Assumptions

Remarks

1.1 Refer to: FAULT TREE IN -A

1.2 Refer to: FAULT TREE IN - B

1.3 Refer to: FAULT TREE IN - C 
WHC-SD-WM-FHA-008, Rev. 0 page 59

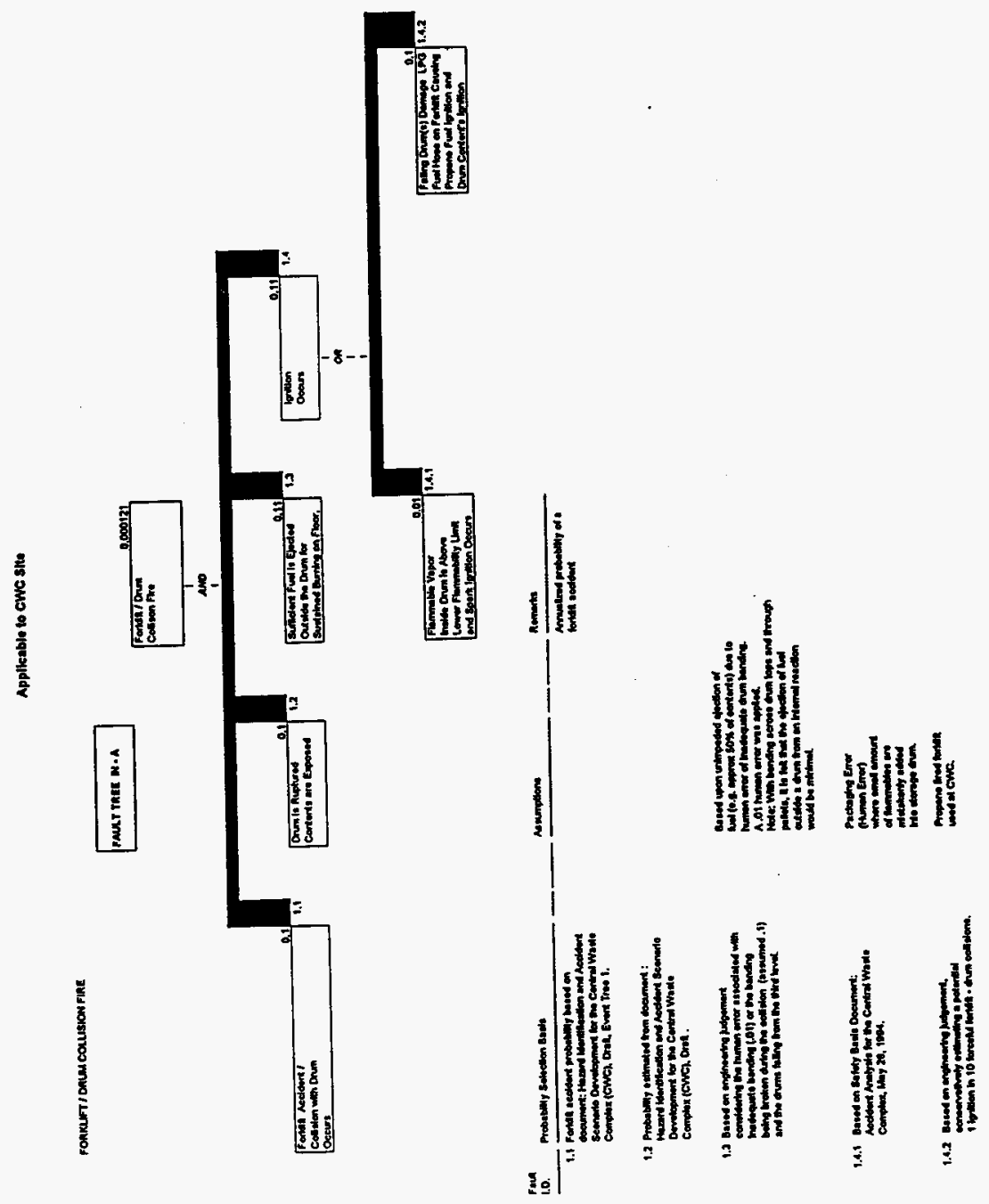


ORUM FIRE CAUSEO OY ABNORMAL REACTON WSIDE DRUM

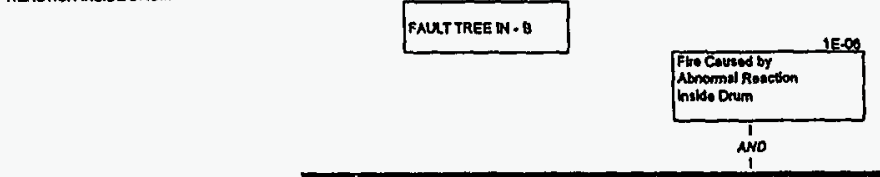

\section{Favin
1.0. Probabiny Solwction Basis}

11 Based on Hexard Lantilestion ans Aoctsont Scensido Dowolopment to

1.2 Enghnoothy duspament

1.5 Enginaeing thdgomont

1.4 Enginearing Judgument
Alsumptions

Rumanks

Spontanuove comdustion

mila drums: .01 based on

- Hunan Error of .ol and

$\alpha$ megntude tor

presence of hecompatiolos in

a lommouantiby lo rosat

Major hid labure is a lahure of

sulitidant slee lo allow contents to be

Assumed resction esuses

host and ppolyth of drum

conlents wo eause lonition

of ojectiod conlents.

Oased upon unimpeded eloction of

tuel (f.s. spprox 5OX of continta) due b

human arox of hadequato divum bandh

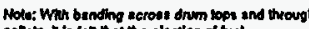

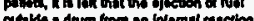

ouster a divm from 
WHC-SD-WM-FHA-008, Rev. 0 page 61
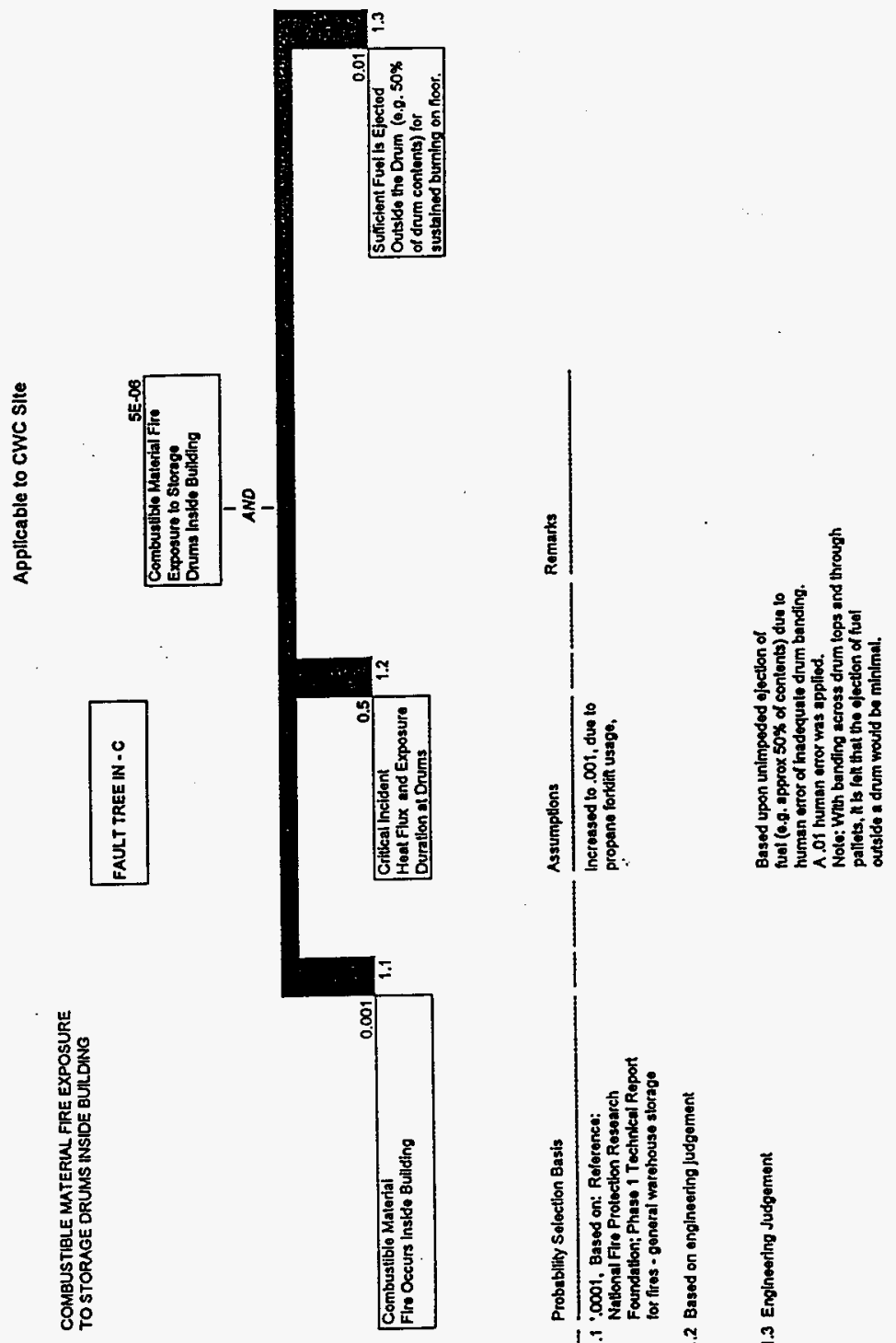


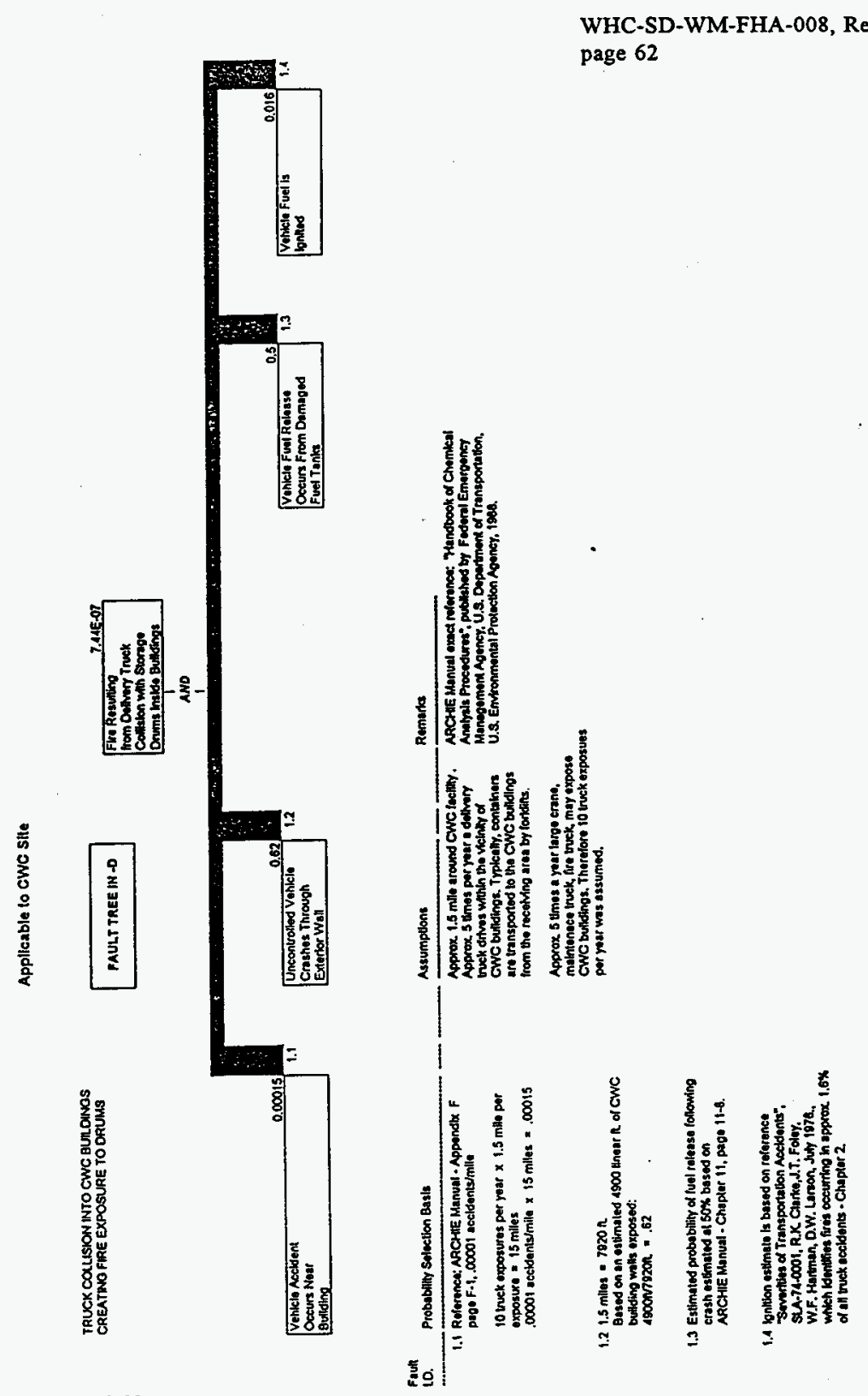


FIRE SEVERTY MODELING

Fine Severity Modeling Objectives

Fire severity modeling objectives included:

- Quantification of the fire propagation phases and associsted heat release rates for palletized storage of solid waste in drums.

- Utilization of the FPE tools fire model to estimate fire exposure versus time. Primary fire exposure variables of concern included:

- Smoke Loyer temperatures inside the building.

Fire Plume ceiling jet temperatures directly over the storage.

Sprinkler System actuation time.

Mass Loss rate(s) profiles.

\subsection{Fire Propagation Fhases and Heat Relense Rates}

Primary fire propagation phases include:

- Phase 1 - Initiating Fire from failure of a solid waste storage drum and ignition of plastic drum contents which burns in pool fire configuration at the floor level.

- Phase 2 - Fire Propagation through the palletized drum storage stacks via wood pallet flame spread and storage drum fuel contribution.

- Phase 3 - Fuel Depletion stage related to transition from flaming combustion to smoldering combustion (i.e., near fuel burnout) as the wood pallets within the drum storage pile are consumed.

\section{Phase I - Initiating Fire}

The following table presents the heat release rate profile for the selected initiating fire scenario. Scenario involves the failure of a storage drum, $50 \%$ plastic fill, resulting in a floor level pool configuration fire. Peak heat release was estimated at $1,561 \mathrm{kw}$ (assuming a 1 sq. meter plastic pool area) with an approximate 15-18 minute burning duration. 
Phase 1 - Initiating Fire - Estimated Heat Release Rate Profile Centrai Waste Compiex Storage Drum Contents

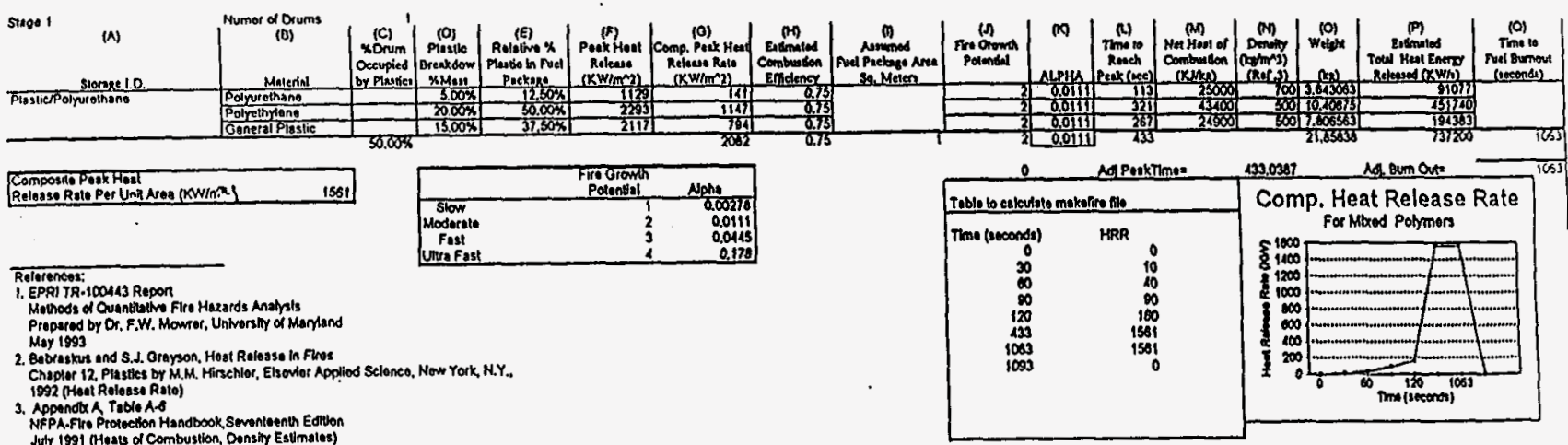


The Phase 1 initiating fire, previously described, grows to $1,561 \mathrm{kw}$ in approximately 7 minutes. It is assumed that the initiating fire occurs within the aisle space between two storage piles. As the initiating fire grows, wood pallets within the adjacent drum storage stacks ignite and propagate the fire. In addition, heat is contributed by the combustion of drum contents projected from the drums or from internal drum smoldering created by the exposing fire and failed drum seals and lids. At approximately 30-60 minutes it is estimated that a steady-state peak beat release oceurs for the combined combustion of the wood pallets and escaping combustible drum contents. This $3,418 \mathrm{kw}$ steady-state heat release rate was estimated based on:

- Wood pallets contribute $2,100 \mathrm{kw}$

- Escaping drum contents contribute 1,318 kw.

Wood Pallet Heat Contribution

Results from recent fire tests (Reference 1) approximated fire spread through a 16 foot long palletized storage pile (four adjacent pallet stacks) in approximately 60-70 minutes. From review of the fire test video [1] it took between 15-30 minutes from pallet flaming combustion and spread to smoldering combustion (near burnout) per drum storage stack.

The SFPE Fire Protection Engineering Handbook, chapter on heat release rate, provides the following graph related to wood pallets.

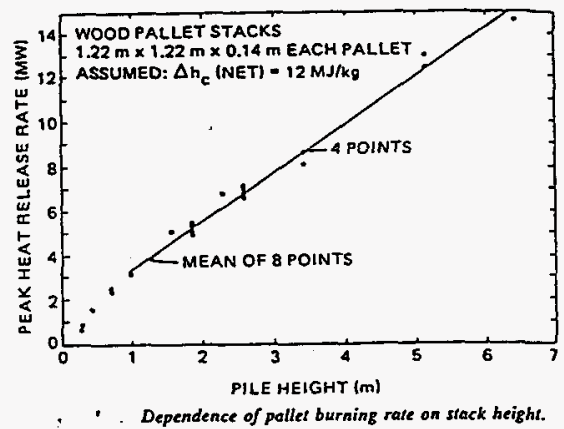

The peak heat release rate from the burning of one idle pallet (i.e., no storage or top) is approximately 700 $\mathrm{kw}$. If the initiating fire occurs in the aisle between storage piles, then initially 6 pallets (drums stored 3 high, 3 pallets per stack, one stack in each pile exposed) are exposed to ignition and fire spread. Assuming 
WHC-SD-WM-FHA-008, Rev. 0 page 66

$25 \%$ of the wood pallet is subject to flaming combustion (based on engineering judgement following review of reference 1) then:

6 pallets exposed X $25 \%$ of pallet subject to flame spread X 700kw/pallet $=1,050 \mathrm{kw}$

If the transition from flaming pallet combustion to smoldering is $15-30$ minutes then there can be 2 pallet stacks in each pile contributing heat, or $2,100 \mathrm{kw}(2 \times 1,050 \mathrm{kw})$.

\section{Dram Contert Heat Contribution}

Results from recent fire test data [1] indicated a total weight loss of approximately $528 \mathrm{lbs}$ of drum content material. The weight loss was estimated by weighing each of the 144 drums used in the fire test prior to the test and following the test, after the drums cooled down. Based on this test data an average mass loss rate of drum contents can be estimated:

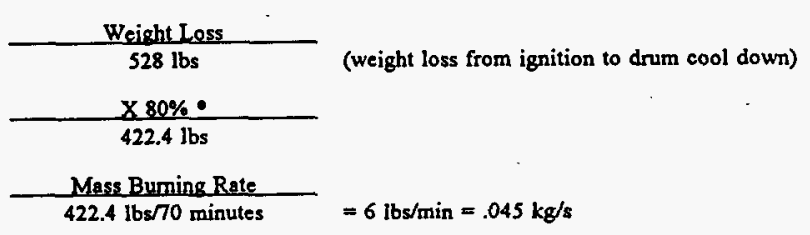

- Assumed $80 \%$ of combustible content mass loss during fire propagation through wood pallets which took approximately $60-70$ minutes.

\section{Convective Heat Release}

The potential convective heat relesse rate $(\mathrm{Qc})$ contributed by drum contents can be estimated as:

$Q_{c}=.7 \times$ Mass Burning Rate X Heat of Combustion

Assumed Convective Heat Release Fraction - .7 [3]

Assumed Heat of Combustion for polyethylene plastic

$Q_{c}=.7 \times .045 \mathrm{~kg} / \mathrm{s} \times 41,825 \mathrm{kj} / \mathrm{kg}=1,317.49 \mathrm{kw}$

In constructing the heat release profile, a heat release rate of $1,318 \mathrm{kw}$ was used to estimate the contribution of heat from escaping drum contents.

During fire tests [1], 18 drums had lid seal failures from the fire exposure; three of these drums had lid top failure. Although drum lid failures occurred along with wood pallet burning, pile stability was maintained during the fire test. 
As an altemative method of estimating drum contents potential heat contribution during a fire, the following information is provided.

The SFPE Fire Protection Engineering Handbook, Chapter or heat release rates, provides the following graph related to trash fire (plastic and paper) heat release rates.

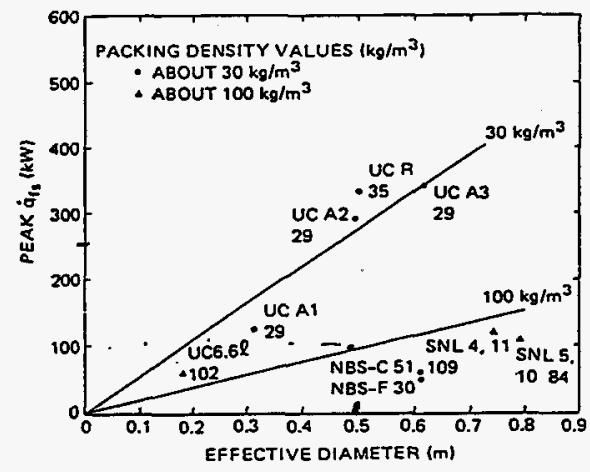

heat relcase role.

As an altemative heat release rate estimste; if 20 drum lid seais fail (approximately $20 \%$ of drums exposed in 2 adjacent piles) and assuming internal drum smoldering - 50\% combustion efficiency, an effective diameter of $.5 \mathrm{~m}$ and an approximate $100 \mathrm{kw}$ average heat release rate output per drum then:

$100 \mathrm{kw} / \mathrm{drum} \times .5$ efficiency $X 20$ drums $=1,000 \mathrm{kw}$ potential heat release rate contributed by drum contents in two storage piles.

Phase 3 - Fire Depletion

Based on review of the fire test data and test video [1] and engineering judgement of fuel depletion and burning duration, it was estimated that at 90 minutes the heat release would be reduced to $50 \%$ of the peak heat release rate, or approximately $1,709 \mathrm{kw}(50 \% \times 3,418 \mathrm{kw}$ ). At 180 minutes ( 3 hours) it was estimated that the fire would be near bumout as the fire would not be expected to propagate beyond 2 storage piles. A $700 \mathrm{kw}$ (approximately $20 \%$ of peak heat release) end point was assumed to account for smoldering (i.e., non-flaming, non-propagating) heat output. 
WHC-SD-WM-FHA-008, Rev. 0 page 68

\section{Heat Release Rate Profile}

The following graph represents the composite Fire Phase $1 \rightarrow$ Fire Phase $2 \rightarrow$ Fire Phase 3 estimated heat release profile for a pelletized solid waste drum storage fire inside a CWC Building.

FIRE HEAT RELEASE RATE PROFILE Palletized Solid Waste Drum Storage

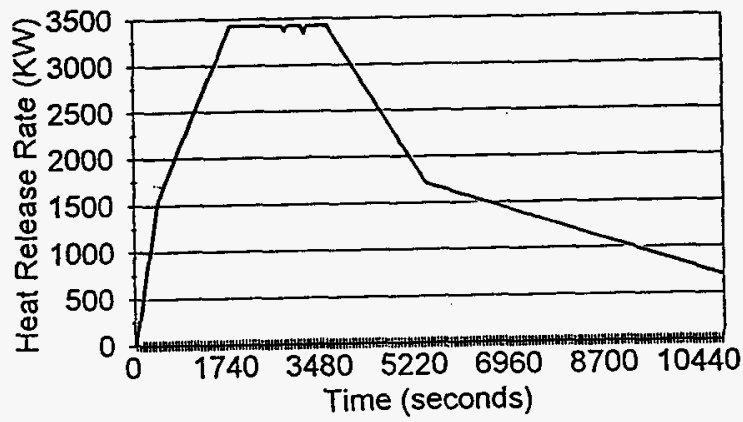


WHC-SD-WM-FHA-008, Rev. 0 page 69

\subsection{EPStools Fire Modeling Output}

The FPETOOLS computerized fire model developed by the National Institute of Standards and Technology (NIST) [2] was used to assist in the fire severity modeling. The input data, computer printouts and spreadsheet datu are located in the CWCRAS document.

The following graphs in this section provide a summary of the selected fire modeling output:

- Representative Small CWC Buildings, $2401-2402$ W - WL

- Scenario Al - Fire with mechanical ventilation OFF

- Scenario A2 - Fire with mechanical ventilation ON

- Representative Moderate Size CWC Buildings, 2403 WA, WB, WC - Scenario B1 - Fire with mechanical ventilation OFF

- Scenario B2 - Fire with mechanical ventilation ON

- Large CWC Building, 2403 WD

- Scensrio $\mathrm{Cl}$ - Fire with mechanical ventilation OFF

- Scenario C2 - Fire with mechanical ventilation ON

Fire modeling information for the CWC Storage pad and LFMW Storage Module 20 or 21 is located in the CWCRAS Document.

The graphs which are presented in this section inelude:

- Smoke Layer Temperature

- Mass Burning Rate - Total from Compusite Fuel Burning

- Mass Loss Rate - Solid Waste Burning

- Mass Release Rate - PU Species Outside of Building

\section{Building Temperarures}

The graphs depicting smoke layer temperatures are averaged temperatures of the hot smoke layer inside the building over the fire duration time. As expected smoke layer temperatures are lower with ventilation fans on (ventilation rate approximated at 4 air changes per hour). In none of the scenarios modeled did the smoke layer temperatures exeeed $11000 \mathrm{~F}$ which could create a situation of building structural failures and major failures of storage drums (i.e., exposure to drums outside the immediate area of fire origin).

In order to provide an estimate of potential ceiling jet plume temperature, which is the temperature directly above the fire source, a fictitious ceiling detector with an operating temperature of $1200 \circ \mathrm{F}$ and located within the ceiling jet region was added into the FPEtools Modeling. This data is located in the FPEtools spreadsbeet output, CWCRAS document. In Scenario Al (Small CWC Buildings - Mechanical Ventilation 
OFF) the ceiling jet temperature exceeded 1100 of for approximately 10 minutes which could cause some failure in terms of opening up seams in the metal deck roof directly above the fire and causing fire products to be vented through the roof. This situation would not be expected to cause structural roof failure. In Scenario A2 with mechanical ventilation on, the peak ceiling temperature was $766 \circ \mathrm{F}$. In the moderate and large size CWC buildings, peak ceiling temperature with ventilation off were in the $700 \circ \mathrm{F}$ tange.

\section{Mass Loss Rate of Solid Wases}

Mass Loss Rates of the solid waste from drums were estimated as $100 \%$ of the total mass burning rate during the first 15 minutes. This is based on the initiating fire scenario involving plastic contents being released from a failed drum and burning as a pool fire on the floor. Following the initiating fire, fuel contribution and burning rate is a combination of wood pallets burning, combustion of drum contents being projected outside of failed drum lids, and internal drum combustion (i.e., smoldering drum contents being released through failed drum seals or lids). The potential mass loss rate of solids following 15 minutes was conservatively estimated at $50 \%$ of the total mass burning rate.

\section{Pocential PU Species Mass Release Rate}

The maximum idealized mass loss of PU species from the solid waste combustion surface can be first estimated by multiplying the solid waste mass loss rate by the fraction of the mass of PU contaminant in the storage drum. Assuming 150 grams PU/drum and a drum loading of $26 \mathrm{~kg}$ Solid Waste, then:

\section{[A]}

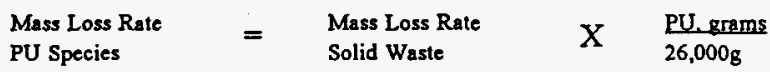

The initiating fire drum loading assumes $200 \mathrm{grams} P U / \mathrm{drum}$ and $26 \mathrm{~kg}$ solid waste. Following the initiating drum fire duration, approximately 15 minutes, an average 24 grams PU/drum was assumed.

To more realistically quantify the mass of $\mathrm{PU}$ species which may be dispersed outside the drum from internal drum combustion, entrained into the fire plume, and released outside of the building envelope, estimates have to be developed for:

- $\%$ of PU species vented out an internally smoldering drum and connectively transported into the fires hot gas layer.

- $\%$ of PU species vented out the building. Since dispersion inside the building will be PU contaminant attached to carbon molecules there will be a fair amount of soot and PU specie deposition within the building envelope. 
WHC-SD-WM-FHA-008, Rev. 0 page 71

The following table provides a breakdown of estimates used to evaluate potential fire induced PU species release fractions outside CWC buildings.

\begin{tabular}{|l|c|c|}
\hline FIRE SCENARYo & $\begin{array}{c}\text { [B] } \\
\text { PU SPECIES } \\
\text { FRACTION VENTED } \\
\text { FROM DRUMS } \\
\text { (LEAKAGE FACTOR) }\end{array}$ & $\begin{array}{c}\text { [C] } \\
\text { PU FRACTION } \\
\text { VENTED OUTSmE } \\
\text { BUILDING }\end{array}$ \\
\hline VENTING FACTOR)
\end{tabular}

The graphs depicting Mass Release Rates of PU species outside of buildings were estimated by:

\begin{tabular}{|c|c|c|c|c|c|c|}
\hline $\begin{array}{l}\text { Mass Loss Rate } \\
\text { PU Species } \\
\text { Outside } \\
\text { Building }\end{array}$ & $=$ & $\begin{array}{l}\text { Idealized } \\
\text { Mass Loss } \\
\text { Rate } \\
\text { PU Species } \\
\quad \text { [A] }\end{array}$ & $x$ & $\begin{array}{l}\text { PU species } \\
\text { vented from } \\
\text { drums } \\
\text { [B] }\end{array}$ & $x$ & $\begin{array}{l}\text { PU species } \\
\text { vented outside } \\
\text { Building } \\
\text { [C] }\end{array}$ \\
\hline
\end{tabular}


WHC-SD-WM-FHA-008, Rev. 0 page 72

Selected Fire Modeling Output

Representative Small CWC Buildings, 2401 - 2402 W - WL

Scenario A1 - Fire With Mechanical Ventilation OFF

CWC SCENARIO A1
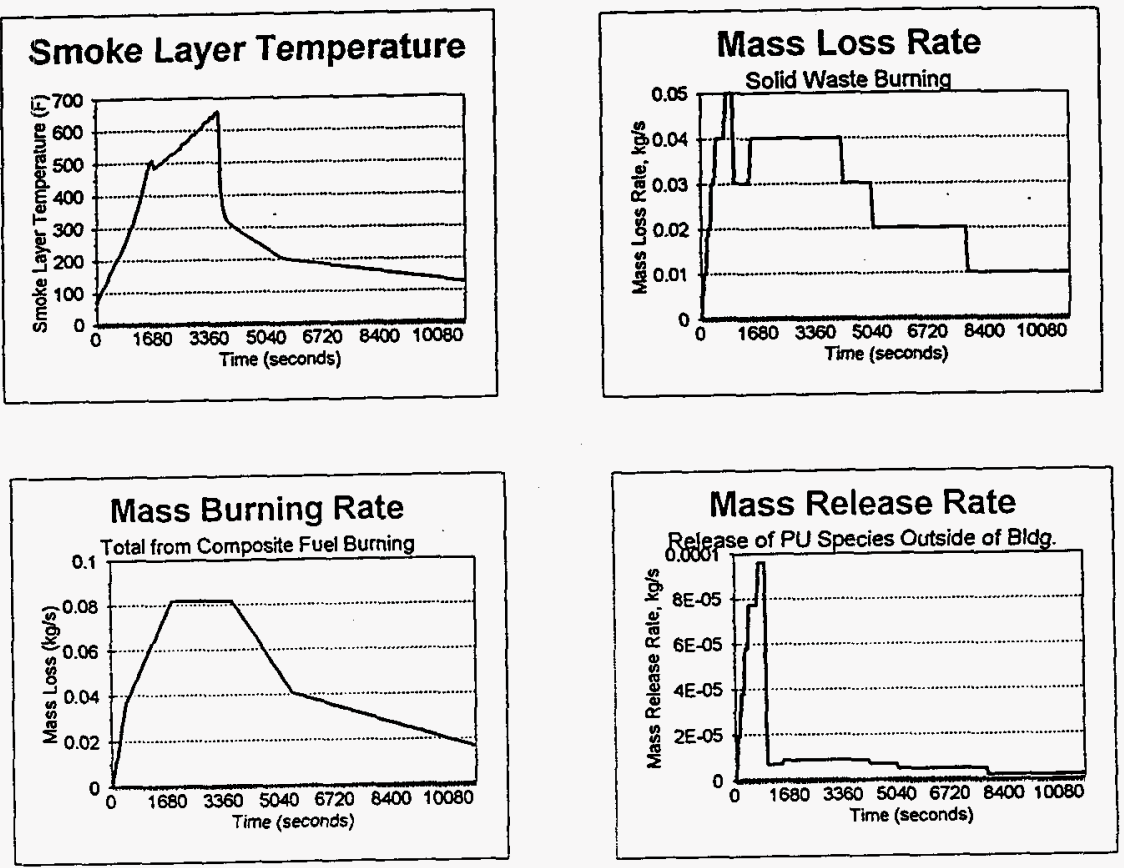
WHC-SD-WM-FHA-008, Rev. 0 page 73

Selected Fire Modeling Output

Representative Small CWC Buildings, 2401 - 2402 W - WL

Scenario A2 - Fire With Mechanical Ventilation ON

CWC SCENARIO A2
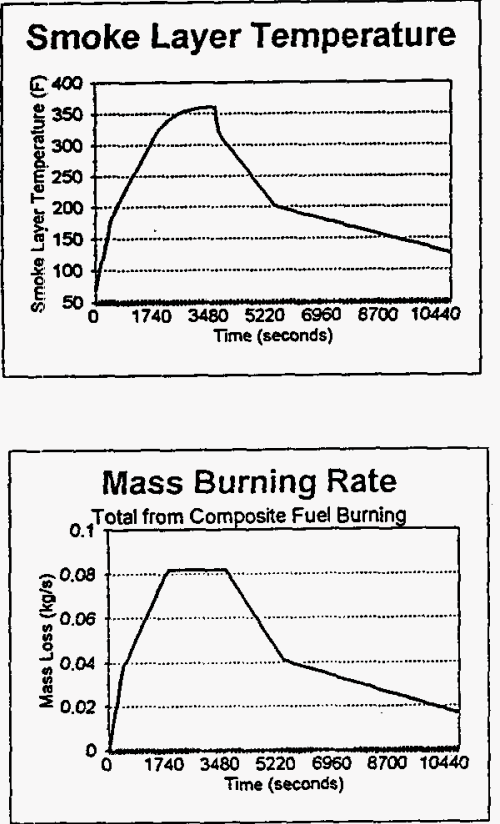
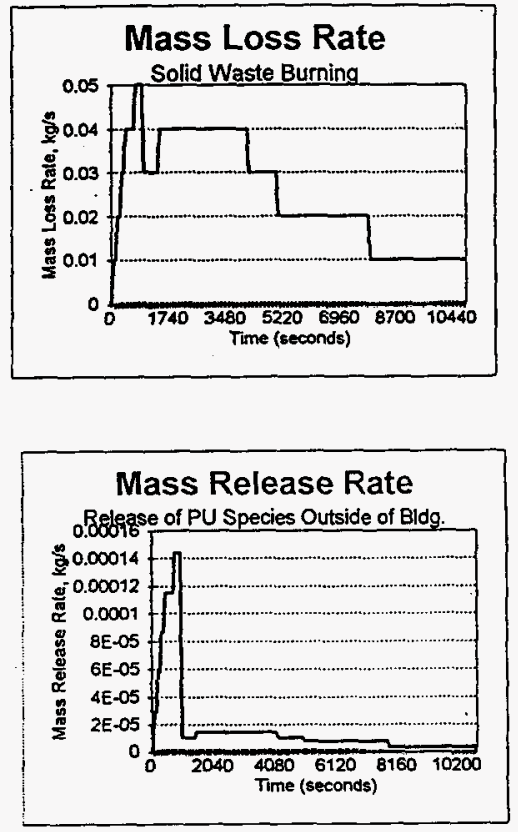
WHC-SD-WM-FHA-008, Rev. 0 page 74

\title{
Selected Fire Modeling Output \\ Moderate Size CWC Buildings, 2403 WA, WB, WC
}

\author{
Scenario B1 - Fire With Mechanical Ventilation OFF
}

CWC SCENARIO B1
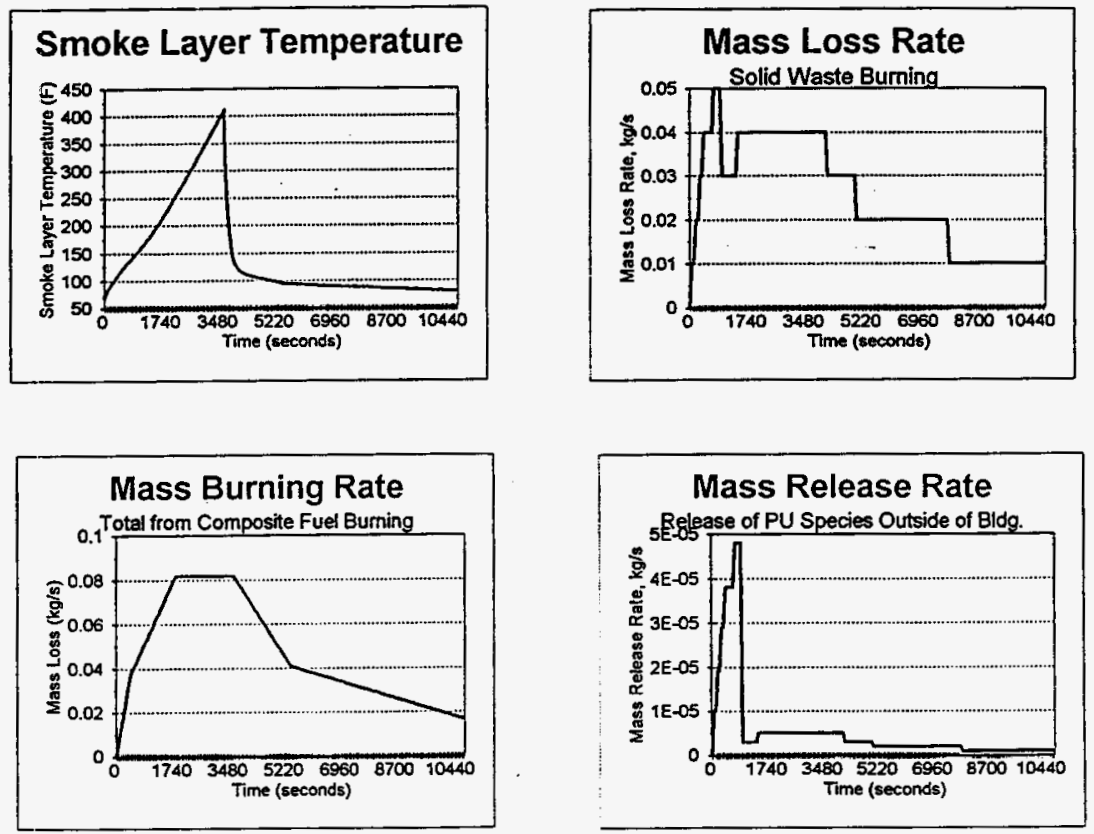
WHC-SD-WM-FHA-008, Rev. 0 page 75

Selected Fire Modeling Output

Moderate Size CWC Buildings, 2403 WA, WB, WC

Scenario B2 - Fire With Mechanical Ventilation ON

CWC SCENARIO B2
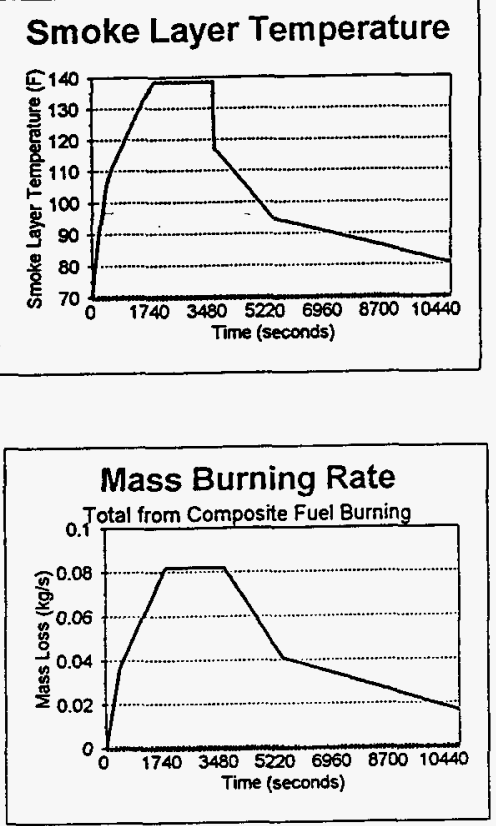
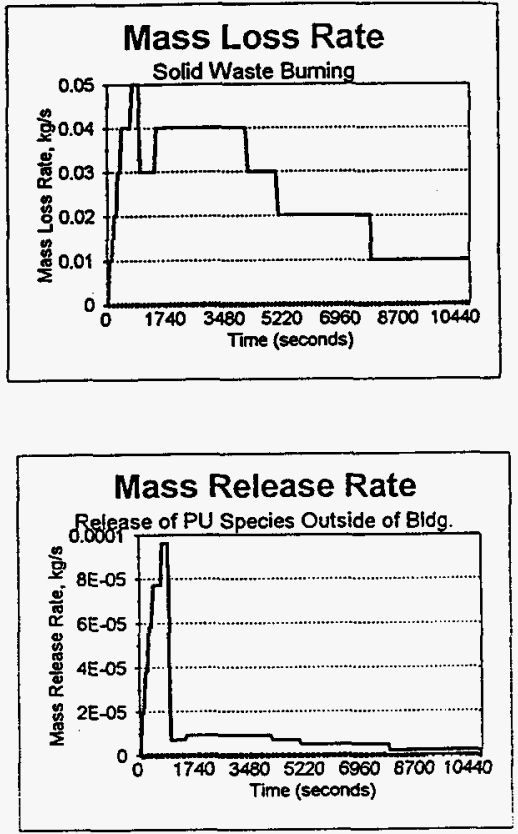
WHC-SD-WM-FHA-008, Rev. 0 page 76

Selected Fire Modeling Output

Large CWC Building, 2403 WD

Scenario C1 - Fire With Mechanical Ventilation OFF

CWC SCENARIO C1
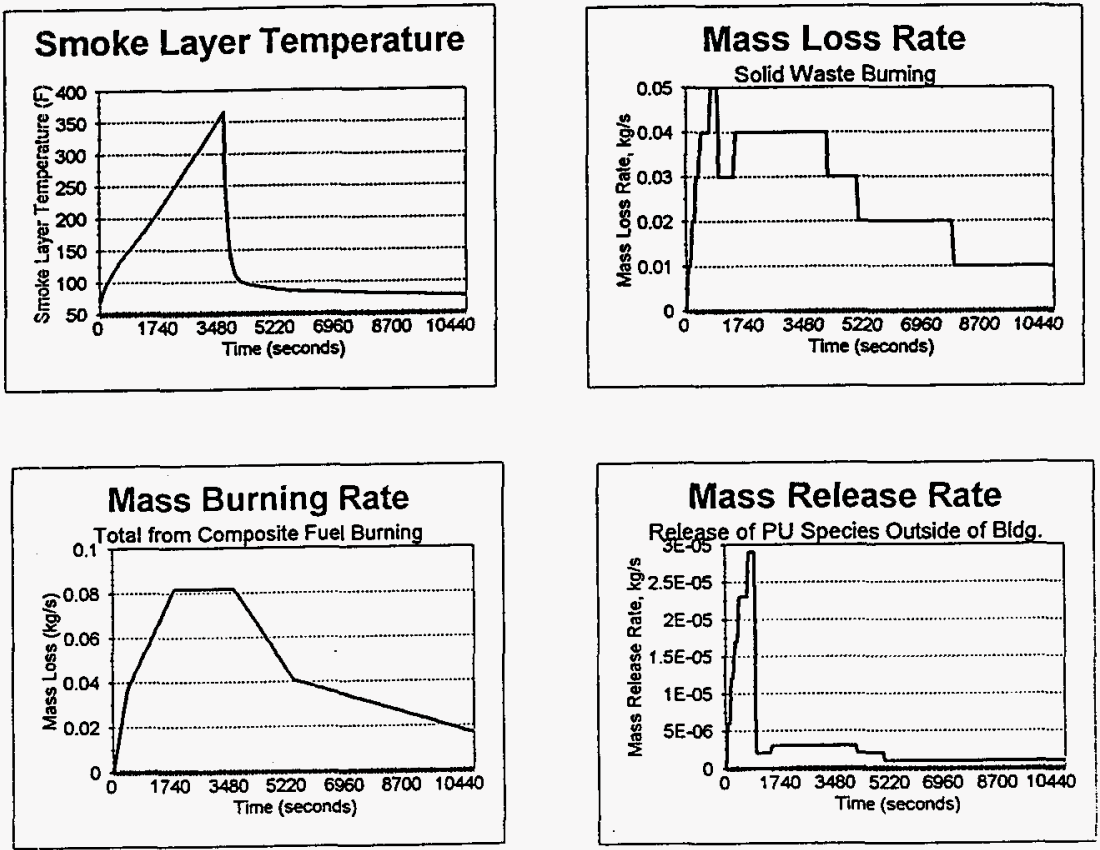
WHC-SD-WM-FHA-008, Rev. 0 page 77

Selected Fire Modeling Output

Large CWC Building, 2403 WD

Scenario C2 - Fire With Mechanical Ventilation $O N$

CWC SCENARIO C2

\section{Smoke Layer Temperature}
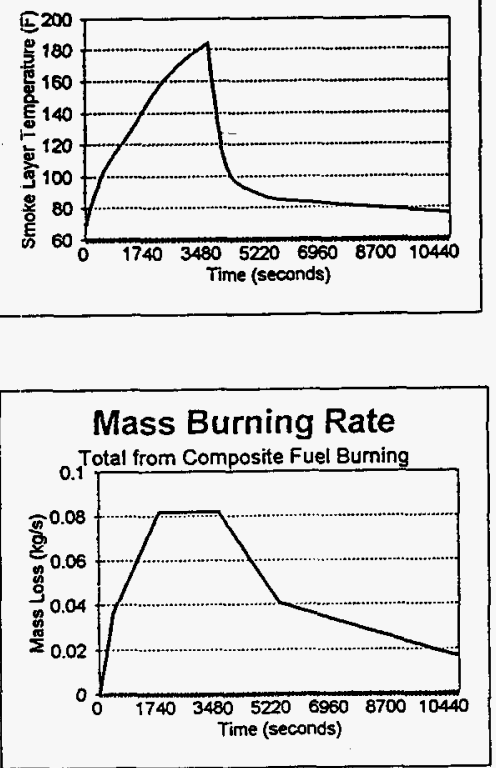
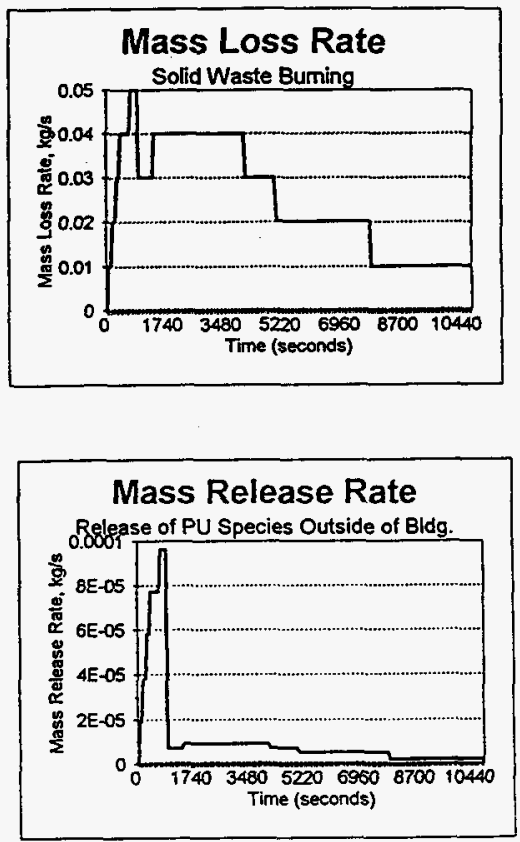
The following event tree analysis (ETA) was conducted to estimate the sequence and probabilities of fire propagation events and to define those pathways which could lead to defined exposure levels for:

- ETA-1 Representative CWC Buildings Palletized Solid Waste Drum Storage

- ETA-2 LFMW Storage Module 20 or 21

Note: Event and fault trees structured for the evaluation of the CWC Storage Pad are located in the CWCRAS Document.

The defined pathway fire exposure levels of interest in this risk assessment include:

- Maximum Credible Fire Loss Probability (MCFL)

- Maximum Foresecable Loss (MFL)

- Maximum Possible Fire Loss Probability (MPFL)

The following table provides a listing of event occurrence versus exposure level definition. MCFL and MPFL meet the FHA loss exposure analysis definitions in DOE Order 5480.7A. MFL is used by some industrial sectors for evaluating improvements in passive fire protection measures, improved reliability in active protection features and improved emergency response. MFL, is normally evaluated after assuming the primary active fire protection system is out of service (which in many cases is the automatic sprinkler system) and then evaluates backup protection systems and/or the responding fire department effectiveness in controlling the fire.

\section{EVENTS}

[A] Initiating Fire Occurs

[B] Employee Suppresses Fire

[C] Fire Detection Successful

[D] Ventilation Fan Shutdown

[E] Fire Propagates to Wood Pallets

[F] Sprinkler Suppression Successful

[G] Fire Dept. Suppression Successful

[H] Fire Propagates Involving Additional Drum Piles

[1] Building maintains Structural Integrity

\begin{tabular}{|l|l|l} 
MCFL & MFL & MPFL \\
\hline Yes & Yes & Yes \\
No & No & No \\
Yes & Yes & Yes/No (1) \\
Yes/No (2) & Yes/No (3) & Yes/No (4) \\
Yes & Yes & Yes \\
Yes & No & No \\
& Yes & No \\
& & Yes \\
& & Yes (5)
\end{tabular}


WHC-SD-WM-FHA-008, Rev. 0 page 79

Remarks:

(1) There are two primary fire detection means in CWC Buildings:

- Sprinkier Syatem Water Flow Alarm

- Manual Fire Alarms activated by Employees

However, detection of the fire will not modify the severity if automatic sprinkler suppression and manual Fire Department suppression fail.

(2) (3) (4) Effect of mechanical ventilation was evaluated by fire modeling. If fire is fuel controlled (mass burning rates not ventilation limited) the running of the fans will not have a significant effect on the mass burning rates. However it will affect the potential release of fire combustion products and radioactive species outside the building.

(5) Building maintains structural integrity based on fire modeling. 


$$
\text { ETA - } 1
$$

Represents CWC Buildings - Palletized Drum Storage of Solid Waste

Event Tree Analysis - CWC Site

\section{ETA FREQUENCY / PROBABILIT INPUT TABLE}

Event Tree Analysis: Eased on existing design, procedures

\begin{tabular}{|c|c|c|c|}
\hline EVENT TREE TTEM & & $\begin{array}{l}\text { FREQUENCY' } \\
\text { PROBABILTYY }\end{array}$ & Selection Method \\
\hline $\begin{array}{l}\text { Inkiatino Fire Occurs } \\
\text { Which Exposes Drutns } \\
\text { Inside Bullding }\end{array}$ & A1 & 0.000127 & $\begin{array}{l}\text { Fault Tree - Risk Sereening Appendix Section } 2.0 \\
\text { For Intiating Drum Fire }\end{array}$ \\
\hline $\begin{array}{l}\text { Employee } \\
\text { Suppreses Fire }\end{array}$ & B1 & 0.05 & $\begin{array}{l}\text { Engineering judoement based on evaluation of employse availability, employee } \\
\text { training. emeroency response procedure (WHC-IP-0263-224T). }\end{array}$ \\
\hline $\begin{array}{l}\text { Fire Detection } \\
\text { System Successfut }\end{array}$ & c1 & 0.9525 & Refer to Faut Tree C1 \\
\hline $\begin{array}{l}\text { Ventitation Exhaust } \\
\text { Fan Shutdown }\end{array}$ & $\begin{array}{l}\text { D1 } \\
\text { D2 }\end{array}$ & $\begin{array}{r}0.0100 \\
0\end{array}$ & $\begin{array}{l}\text { Exhaust fan is not interlocked to shutdown upon operation of the sprinder systern. } \\
\text { There is a manual shuldown located on the outside of the building wall, however it is } \\
\text { next to the extaust fan and during a fire stuation would not be very accessible. }\end{array}$ \\
\hline $\begin{array}{l}\text { Fire Propagates } \\
\text { to Wood } \\
\text { Pallets }\end{array}$ & $\begin{array}{l}\text { E1 } \\
\text { E2 } \\
\text { E3 }\end{array}$ & $\begin{array}{l}0.9 \\
0.9 \\
0.9\end{array}$ & Engineering judgement following review of fire tests ( Reference i) \\
\hline
\end{tabular}

Autornatic Spriniker Suppression

F1 Successful

Manual Fire Dept. Suppression Successful

Fire Propagates Involving Additional Storage Piles (i.e. beyond the 2 initial stoage piles exposed)

$\begin{array}{ll}\text { G1 } & 0.95 \\ \text { G2 } & 0.99 \\ \text { G3 } & 0.95 \\ \text { G4 } & 0.99 \\ \text { G5 } & 0.01 \\ \text { G6 } & 0.01\end{array}$

0.885978

0.98442

0.885978

0.98442

0.885978

0.98442

Refer to Faut Tree F1; reduced $10 \%$ for fire shielding. propagation through pallet

Sarne as FY

Same as F1

Based on interview with Eattalion Chief, who indicated response within 7 minutes fic time of alarm and by hose to fire area within 3 minutes after arrival. Assigned 99 probability to situation were fire does nol propagale

If Fire Dept. is not notified by normal means, assigned very low fiklihood of success! based on notification by person(s) remotely located from this building.

Based on Engineering Judgement following review of Fire Tests (Reference 1) 
WHC-SD-WM-FHA-008, Rev. 0 page 81

EVENT TREE ANALYSIS (ETA)

Represents CWC Bulldings - Palletized Onum Storage of Solld Wastes

ETA - 1

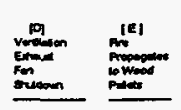

If)

|W|

iming

Axter

IIf

acers

$\min$

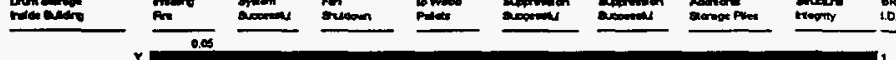

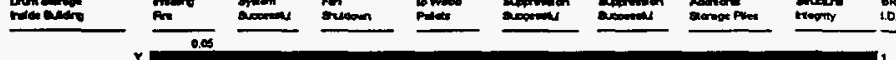

Malmus Probatic vermom

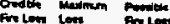

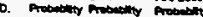

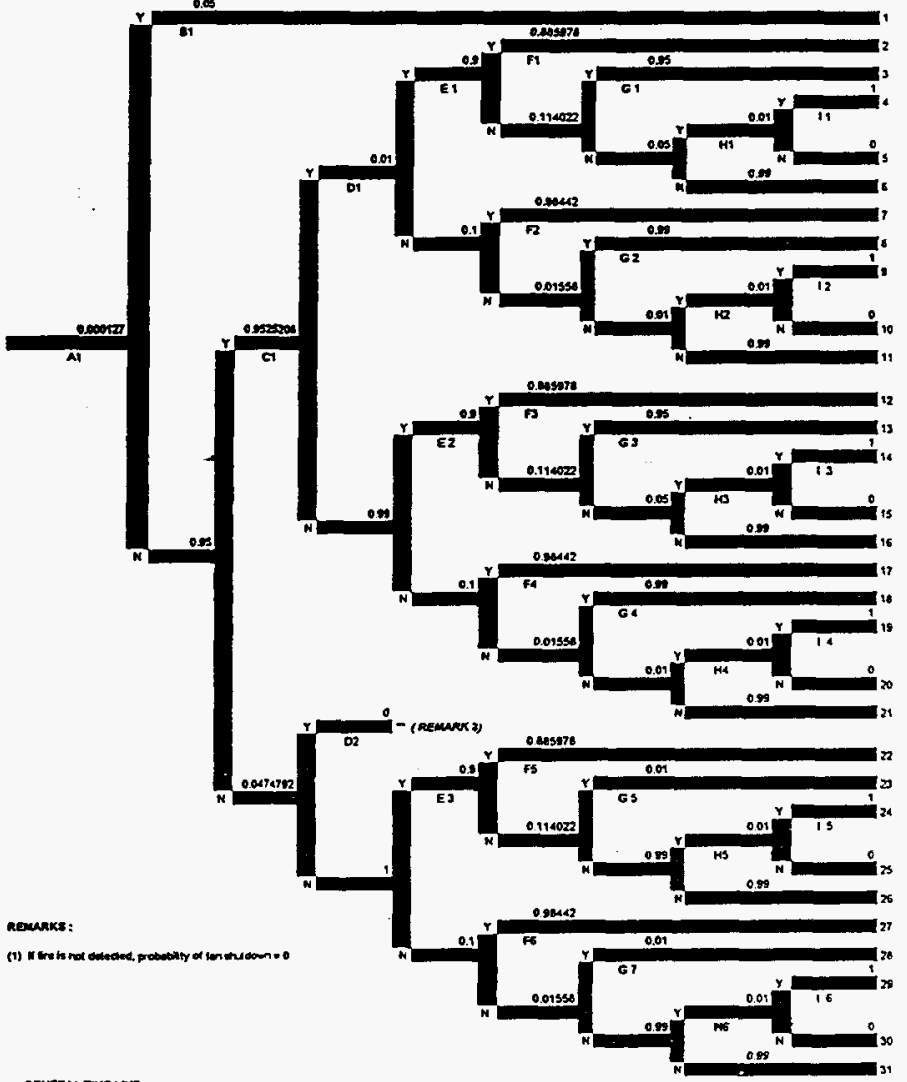

GENERU TUE un

IAf

(5) (5) (5)

Endover Fir

Sopivivi Detecton Vertiat

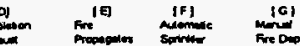

Fire $_{\text {[H] }}^{[\mathrm{H}]}$

Propopetes Gendrs

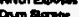
moses

strom fen to whod

sintwe

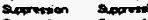

(a)

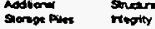

D. 10 minues

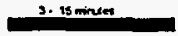

10.30 minses

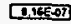

1.13E:07]

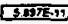

वस्क

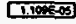

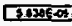

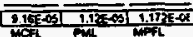

mort rim

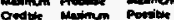

freton ton fortens

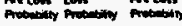

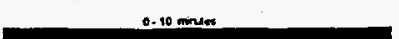

30. 190 monse

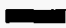


Represents LFMW Storage Modules 20, 21

Event Tree Analysis - cWC Site

\section{ETA FREQUENCY / PROBABILITY INPUT TABLE}

Event Tree Analysis: Based on existing design, procedures

\begin{tabular}{|c|c|c|c|}
\hline EVENT TREE ITEM & & $\begin{array}{l}\text { FREQUENCY } \\
\text { PROEABIUTY }\end{array}$ & Selection Method \\
\hline $\begin{array}{l}\text { Initiating Fire Ocewrs } \\
\text { Which Exposes Drums } \\
\text { Inside Building }\end{array}$ & A1 & 0.000127 & $\begin{array}{l}\text { Fauk Tree - Risk Soreaning Appendix Section } 2.0 \\
\text { For Inkiating Drum Fire } \\
\text { Note: Used ame inkizing drum fire frequency as CWC Eulidings }\end{array}$ \\
\hline $\begin{array}{l}\text { Employee } \\
\text { Suppresses Fire }\end{array}$ & $\mathbf{8 1}$ & 0.05 & $\begin{array}{l}\text { Engineering judgement besed on evaluation of employed availabitity, employe } \\
\text { trining. }\end{array}$ \\
\hline $\begin{array}{l}\text { Fire Detection } \\
\text { Syctem Successfut }\end{array}$ & C1 & 0.4160 & 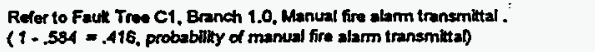 \\
\hline $\begin{array}{l}\text { Ventliation Exhaust } \\
\text { Fan Shutdown }\end{array}$ & D1 & $\begin{array}{r}0.0100 \\
0\end{array}$ & Estimated probabitity of manual vertitation tan shutdown. \\
\hline $\begin{array}{l}\text { Fire Propagetes } \\
\text { for } 15 \text { minutes. }\end{array}$ & $\begin{array}{l}\text { E1 } \\
\text { E3 }\end{array}$ & $\begin{array}{l}0.5 \\
0.5 \\
0.5\end{array}$ & $\begin{array}{l}\text { Eased on fire modeling, estimated bum out time from a single } 55 \mathrm{gal} \text {. drum } \\
\text { uncortrolled fire, would be appox. } 18-20 \text { minutes, based on a londing of } \\
\text { approx. } 48 \mathrm{~kg} \text {. frev liquid solvent and } 20 \mathrm{~kg} \text {. plastic. }\end{array}$ \\
\hline
\end{tabular}

Attomatic Dry Chemical System Suppression Successful

F 1

$\mathrm{F2}$

$F 3$

F4

FS

F6

Manual Fire Dept. Suppression Successiul

Fire Propegates Involving Additional Storage Dums

Guilding Maintains Structural Integrity
There is NO automatic dry chemical protection system installed in Modules 20,21

Based on interview with Battalion Chief, who indicated response wathin 7 minutes time of alarm and lay hose fo fire area within 3 minutes atter arrival.

If Fire Dept. is not notified by nommal means, assigned very low likdihood of success based on notification by person(s) remotely located forn this building.
55 gation drums we stored one high. There are no wood of plastic paliets in the storage module, however drums contain fammable free liquids. If subjected to the radiant heat fluxes and temperatures of a direct exposure fire (l.e. fire adjacerk to storage drum) the drums seal may fail and pyrolyzed fuel vapors may escape and ignile, thus extending the fire duration.

Probabilities based on consenvative engineering judgement.

\footnotetext{
Based on fire modeling, storage modules may sart to fail within $10-20$ minutes.
}

NOTE: Based on fire modeling, fire should not propogate batween modules. 
WHC-SD-WM-FHA-008, Rev. 0

page 83

EVENT TREE ANALYSIS (ETA)

Represenes LFWW Storage Modutes 20, 21

ETA - 2

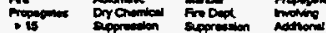

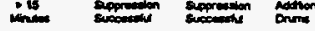
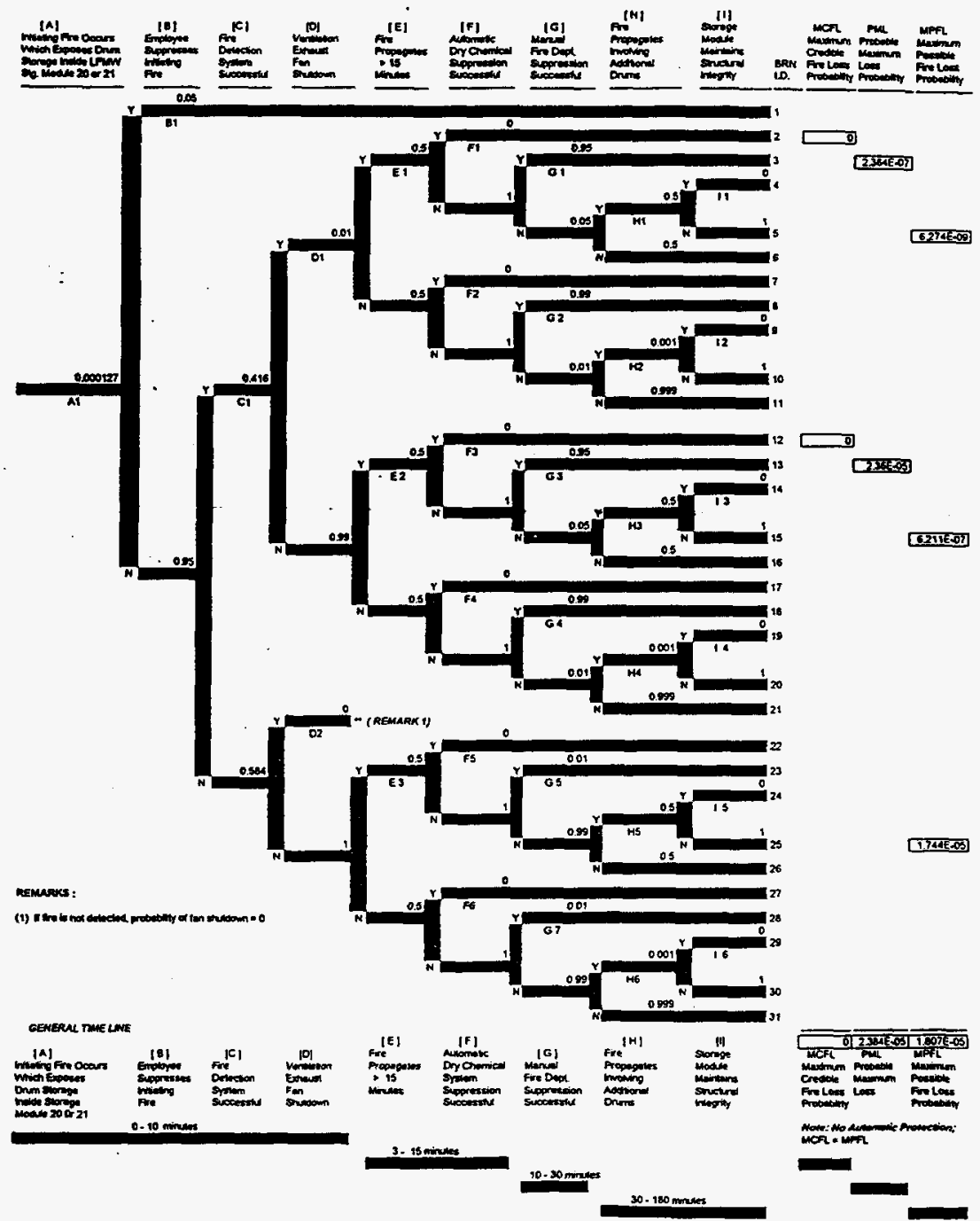
Represents CWC Bulldings - Palletized Drum Storage of Solld Waste
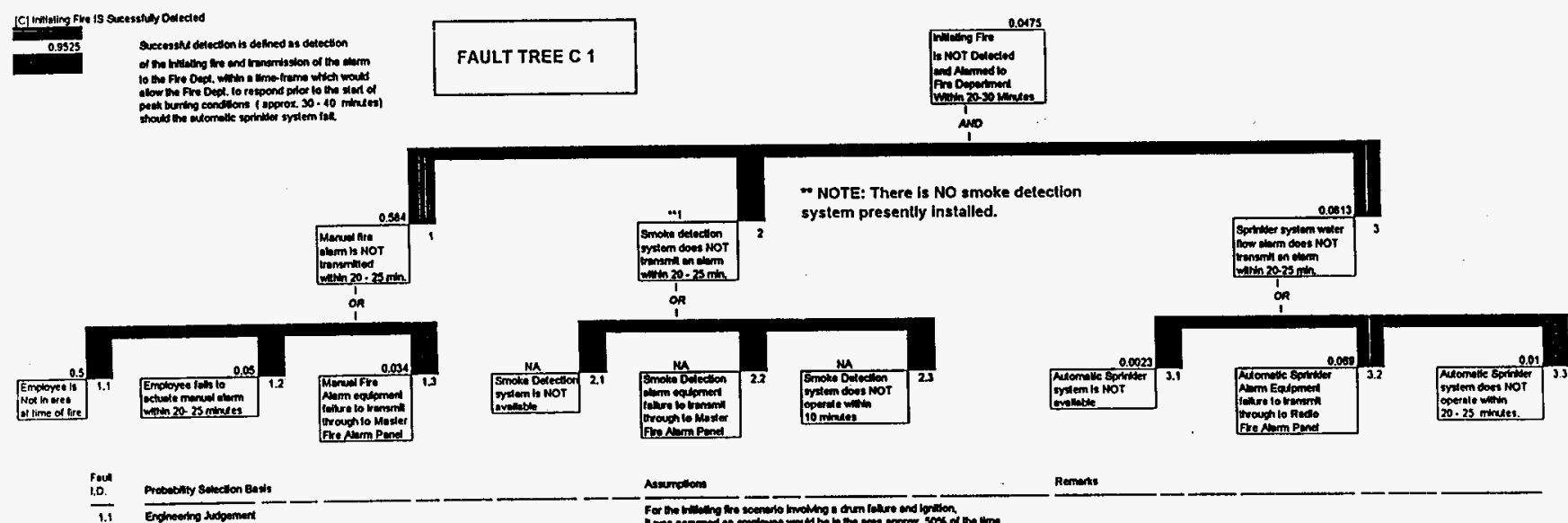

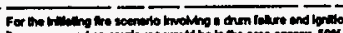

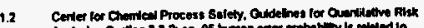

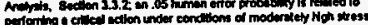

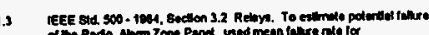

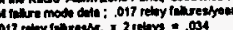

Rements

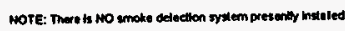

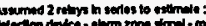

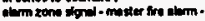
tromintisten ropel retrys.

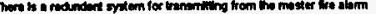
ond tested the Fiverily. 


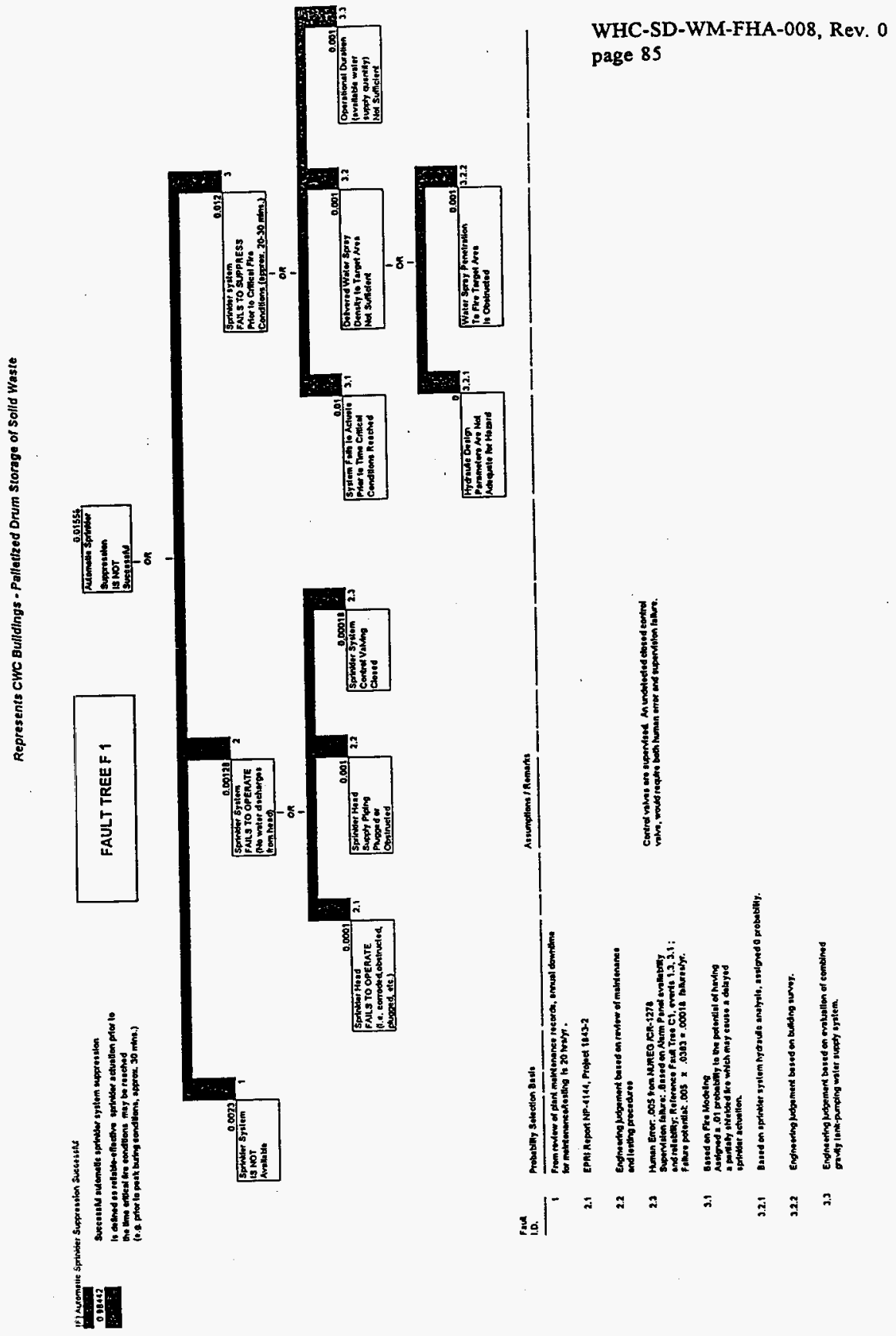




\subsection{RISK ESTMMATION}

The following risk profiles combine the results of the fire severity modeling with the probability estimations of MCFL, MFL, and MPFL events developed in section 4.0 of this Appendix.

The risk profiles present the estimated fire induced $\mathrm{PU}$ release potential outside of $\mathrm{CWC}$ buildings in terms of annualized probability and release size. Risk Profiles were developed for:

- Risk Profile Al - Representative of Small CWC Buildings 2401-2402W-WL Fire Seenario Al - Fire with Mechanical Ventilation OFF

- Risk Profile A2 - Representative of Small CWC Buildings 2401-2402W-WL Fire Scenario Al - Fire with Mechanical Ventilation ON

- Risk Profile B1 - Representative of Moderate Size CWC Buildings 2403 WA, WB, WC Fire Scenario $\mathrm{Bl}$ - Fire with Mechanical Ventilation OFF

- Risk Profile B2 - Representative of Moderate Size CWC Buildings 2403 WA, WB, WC Fire Scenario B2 - Fire with Mechanical Ventilation ON

- Risk Profile $\mathrm{Cl}$ - Representative of Large CWC Buildings 2403 WD Fire Scenario $\mathrm{Cl}$ - Fire with Mechanical Ventilation OFF

- Risk Profile C2 - Representative of Large CWC Buildings 2403 WD Fire Secnario C2 - Fire with Mechanical Ventilation ON

- Risk Profile D - Representative of LFMW Storage Module 20 or 21

- Risk Profile E - Represents CWC Outside Storage Pad 
WHC-SD-WM-FHA-008, Rev, 0 page 87

\section{RISK PROFILE A1}

Representative Small CWC Buildings, $2401-2402 W$ - WL

Scenario A1 - Fire with Mechanical Ventilation OFF

MCFL

Maximum Credible Fire Loss

\begin{tabular}{|c|c|c|}
\hline Spriniver Activation Time & 8.76 & Minuster \\
\hline $\begin{array}{c}\text { Smoise byer Temp. } \\
8.76 \text { minutes }\end{array}$ & 192 & $\mathbf{F}$ \\
\hline 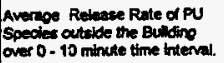 & \multicolumn{2}{|c|}{ S.4E-OS koks } \\
\hline $\begin{array}{l}\text { Accumulative reletese of PU } \mathrm{B} \\
\text { 8.76 minutes } \\
\text { Outside the Bulding }\end{array}$ & \multicolumn{2}{|c|}{ 28.2773 Grams PU } \\
\hline $\begin{array}{l}\text { Annualized Probability } \\
\text { of MCFL Event }\end{array}$ & \multicolumn{2}{|c|}{ 9.2E-05 eventshyest } \\
\hline $\begin{array}{l}\text { MCFL ecenario assumes sprinis } \\
\text { Sprinider activation time was est }\end{array}$ & ler system: & $\begin{array}{l}8 \text { operate. } \\
\text { ing FPETod }\end{array}$ \\
\hline
\end{tabular}

MFL

Maximum Foreseeable Loss

\begin{tabular}{|c|c|c|}
\hline $\begin{array}{l}\text { Fire Departinent } \\
\text { Fire Control Time }\end{array}$ & 30 & Minutes \\
\hline $\begin{array}{c}\text { Smoke tayer Temp. } 8 \\
30 \text { minutes }\end{array}$ & 655 & $F$ \\
\hline $\begin{array}{l}\text { Average Relesse Rate of PU } \\
\text { Species outside the Building } \\
\text { over 0-30 minute fine irterval. }\end{array}$ & \multicolumn{2}{|c|}{$3.2505 \mathrm{k} / \mathrm{k}$} \\
\hline $\begin{array}{l}\text { Acoumulatine retease of PU } \\
\text { so minutes } \\
\text { Outside the Bulloing }\end{array}$ & \multicolumn{2}{|c|}{69.3931 Grems PU } \\
\hline $\begin{array}{l}\text { Annualized Probability } \\
\text { of MFL Evend }\end{array}$ & \multicolumn{2}{|c|}{ 1.1E-05 eventsiyesr } \\
\hline $\begin{array}{l}\text { MFl scenatio assumes sprinkte } \\
\text { howevet fite control ts achieved } \\
\text { approvimately } 30 \text { mintues from }\end{array}$ & $\begin{array}{l}\text { or system o } \\
\text { by Fire De } \\
\text { the stat of }\end{array}$ & $\begin{array}{l}\text { ces not oper } \\
\text { partment wit } \\
\text { the fire. }\end{array}$ \\
\hline
\end{tabular}

MPEL

Maximum Possible Fire Loss

\begin{tabular}{|c|c|c|}
\hline Fire Duretion Limit & 180 & Mintses \\
\hline $\begin{array}{c}\text { Smoke byer Temp. } 8 \\
180 \text { minutes }\end{array}$ & 126 & $F$ \\
\hline $\begin{array}{l}\text { Avernoe Reicate Rate of PU } \\
\text { Species outside the Guiding } \\
\text { over } 0 \text { - } \$ 80 \text { minute fine interval. }\end{array}$ & \multicolumn{2}{|c|}{ 1.1EOS kols } \\
\hline $\begin{array}{l}\text { Accumulative relesse of PU e } \\
\text { I80 mintes } \\
\text { Outelde the Euilding }\end{array}$ & \multicolumn{2}{|c|}{114 Grams PU } \\
\hline $\begin{array}{l}\text { Annualized Prabobilily } \\
\text { of MPFL Event }\end{array}$ & \multicolumn{2}{|c|}{ 1.2E-08 events/year } \\
\hline \multicolumn{3}{|c|}{$\begin{array}{l}\text { MPFL assumes sprinider systems do not operate and } \\
\text { Fire Department does not respond. }\end{array}$} \\
\hline
\end{tabular}

$$
\begin{aligned}
& \text { SCENARIO A1 } \\
& \text { DATA TABLE } \\
& \begin{array}{lr}
\text { Probebility } & \text { PU. Grams } \\
\hline 9.16 E-05 & 28.2773 \\
1.12 E-05 & 69.3931 \\
1.17 E-08 & 114
\end{array}
\end{aligned}
$$

$$
\int \text { Aver }
$$


WHC-SD-WM-FHA-008, Rev. 0 page 88

\section{RISK PROFILE A2}

Representative Small cWC Buildings, 2401 - 2402W - WL

Scenario A2 - Fire with Mechanical Ventilation ON

IMCFL

Maximum Credible Fire Loss

\begin{tabular}{|c|c|c|}
\hline Sprinker Activation Time : & 9.35 & Minutes \\
\hline $\begin{array}{c}\text { Smoke layer Terrp. } 8 \\
9.35 \text { minutes }\end{array}$ & 198 & $\mathbf{F}$ \\
\hline $\begin{array}{l}\text { Awernge Retease Rate of PU } \\
\text { Species outsibe the Builing } \\
\text { over } 0 \text { - } 10 \text { minute time linterval. }\end{array}$ & \multicolumn{2}{|c|}{$8.1 \mathrm{E}-05 \mathrm{~kg} / \mathrm{s}$} \\
\hline $\begin{array}{l}\text { Acoumulatime release of PU } 9 \\
9.35 \text { minutes } \\
\text { Outside the Building }\end{array}$ & \multicolumn{2}{|c|}{45.3288 Grams PU } \\
\hline $\begin{array}{l}\text { Annualized Probability } \\
\text { of MCFL Event }\end{array}$ & \multicolumn{2}{|c|}{ 8.2E-05 evertshear } \\
\hline $\begin{array}{l}\text { MCFl scenario assumes aprinkt } \\
\text { Sprinkder activation time was esti }\end{array}$ & $\begin{array}{l}\text { er syatems } \\
\text { imsted unir }\end{array}$ & $\begin{array}{l}\text { operate. } \\
\text { ng FPET }\end{array}$ \\
\hline
\end{tabular}

MFL

Maximum Foreseeable Loss

\begin{tabular}{|c|c|c|}
\hline $\begin{array}{l}\text { Fire Departmert } \\
\text { Flae Confrol Time }\end{array}$ & 30 & Minutes \\
\hline $\begin{array}{c}\text { Smolke loyer Temp. } \\
30 \text { minutes }\end{array}$ & 316 & $F$ \\
\hline $\begin{array}{l}\text { Avernge Relesese Rate of PU } \\
\text { Species outtide the Buldorng } \\
\text { over } 0 \text { - } 30 \text { minute tims interval. }\end{array}$ & \multicolumn{2}{|c|}{$5.8 E-05 \mathrm{~kg} / \mathrm{s}$} \\
\hline $\begin{array}{l}\text { Acammlative molese of PU } 8 \\
30 \text { minutes } \\
\text { Outside the Euiding }\end{array}$ & 104.0897 & Grems PU \\
\hline $\begin{array}{l}\text { Annualized Probability } \\
\text { of MFL Evert }\end{array}$ & \multicolumn{2}{|c|}{ T.1E-05 everisfyear } \\
\hline $\begin{array}{l}\text { MFL camario assumet sprinkte } \\
\text { howevet fire control is achieved } \\
\text { opprowimately } 30 \text { mintues from }\end{array}$ & $\begin{array}{l}\text { er syctem od } \\
\text { by fine Def } \\
\text { the start of }\end{array}$ & $\begin{array}{l}\text { oes not operat } \\
\text { partment withit } \\
\text { the fire. }\end{array}$ \\
\hline
\end{tabular}

MPFL

Maximum Possible Fire Loss

\begin{tabular}{|c|c|c|}
\hline Fire Duration Limi & 180 & Minutes \\
\hline $\begin{array}{c}\text { Smoke layer Temp. } 2 \\
180 \text { minutes }\end{array}$ & 127 & $\mathbf{F}$ \\
\hline $\begin{array}{l}\text { Average Release Rate of PU } \\
\text { Species outside the Busiding } \\
\text { over } 0.960 \text { minute time interval. }\end{array}$ & \multicolumn{2}{|c|}{$1.6505 \mathrm{~kg} / \mathrm{s}$} \\
\hline $\begin{array}{l}\text { Accumulative relesse of PU } \\
180 \text { minutes } \\
\text { Outside the Building }\end{array}$ & \multicolumn{2}{|c|}{170.28 Grams PU } \\
\hline $\begin{array}{l}\text { Annualized Probability } \\
\text { or MPF, Event }\end{array}$ & \multicolumn{2}{|c|}{$1,2 E-08$ evertsyess } \\
\hline $\begin{array}{l}\text { MPFL assumes sprinider syctems } \\
\text { Fire Department doet not respond }\end{array}$ & d. do not op & verate and \\
\hline
\end{tabular}

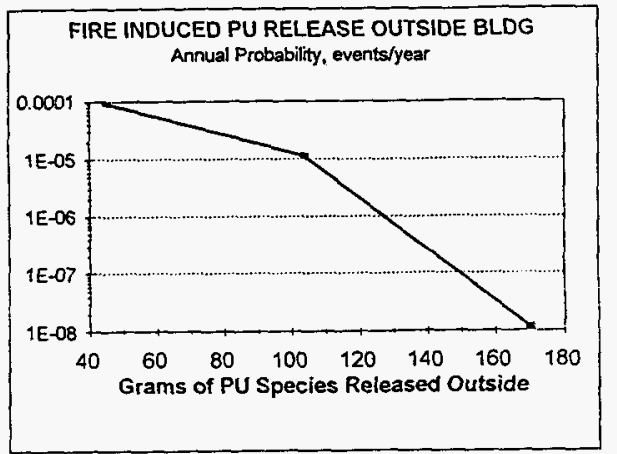


WHC-SD-WM-FHA-008, Rev. 0 page 89

\section{RISK PROFILE B1}

Representative Moderate Size CWC Buildings, 2403WA. WB, WC

Scenario B1 - Fire with Mechanical Ventilation OFF

MCFL

Maximumn Credible Fire Loss

\begin{tabular}{|c|c|c|}
\hline Spriniser Aetivation Time :- & 17.55 & Minutes \\
\hline $\begin{array}{l}\text { Smoke loyer Temp. } \\
17.55 \text { minutes }\end{array}$ & 159 & $\mathbf{F}$ \\
\hline 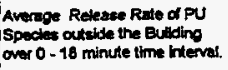 & \multicolumn{2}{|c|}{ 2.8E-OS kot } \\
\hline $\begin{array}{l}\text { Acoumulative release of PU } 8 \\
17.55 \text { minutes } \\
\text { Outside the Euilding }\end{array}$ & \multicolumn{2}{|c|}{29.6595 Grams PU } \\
\hline $\begin{array}{l}\text { Annualized Frobability } \\
\text { of MCAL Event }\end{array}$ & \multicolumn{2}{|c|}{ 9.2E-CS evertategr } \\
\hline $\begin{array}{l}\text { MCFL scensio assumes eprinlo } \\
\text { Sprinider activation time wes ed }\end{array}$ & $\begin{array}{l}\text { or syatems } \\
\text { inated usin }\end{array}$ & $\begin{array}{l}\text { operate. } \\
\text { n FPETool }\end{array}$ \\
\hline
\end{tabular}

MFL

Maximum Foreseeable Loss

\begin{tabular}{|c|c|}
\hline $\begin{array}{l}\text { Fire Department } \\
\text { Five Contrel Trise }\end{array}$ & 38 Minutes \\
\hline $\begin{array}{c}\text { Smoke byer Temp. } 8 \\
38 \text { minutes }\end{array}$ & $268 F$ \\
\hline $\begin{array}{l}\text { Average Relesse Rate of PU } \\
\text { Spectes outside the Bulding } \\
\text { oner } 0.38 \text { minute time inderval. }\end{array}$ & $1.6 \mathrm{E}-0 \mathrm{stos}$ \\
\hline $\begin{array}{l}\text { Accumulative release \& PU Q } \\
38 \text { minutes } \\
\text { Outsicle the Building }\end{array}$ & 35.82 Grams PU \\
\hline $\begin{array}{l}\text { Annualized Probability } \\
\text { of MFL Evert }\end{array}$ & 1.9E.05 evertsyear \\
\hline 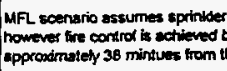 & $\begin{array}{l}\text { Ifere Department with } \\
\text { atart of the fire. }\end{array}$ \\
\hline
\end{tabular}

MPFL

Maximum Possible Fire Loss

\begin{tabular}{|c|c|}
\hline Fire Duration Limh & 180 Minutes \\
\hline $\begin{array}{c}\text { Smake iayer Temp. } \\
180 \text { minutes }\end{array}$ & $60 \mathrm{~F}$ \\
\hline $\begin{array}{l}\text { Averege Release Rate of PU } \\
\text { Species outuide the Bulding } \\
\text { over } 0-180 \text { minute time interval. }\end{array}$ & $5.2 \mathrm{E}-0.0 \mathrm{~kg} / \mathrm{s}$ \\
\hline $\begin{array}{l}\text { Accumulatime release of PU } 8 \\
160 \text { mimutes } \\
\text { outeide the Bulling }\end{array}$ & $\begin{array}{c}\text { 56.16 Gam PU } \\
-\end{array}$ \\
\hline $\begin{array}{l}\text { Annualized Probsbility } \\
\text { of MPFL Event }\end{array}$ & $1.2 E$ os evente/year \\
\hline $\begin{array}{l}\text { MPFL issumes sprinkter systems } \\
\text { Fire Department does not respor }\end{array}$ & do not operate and \\
\hline
\end{tabular}

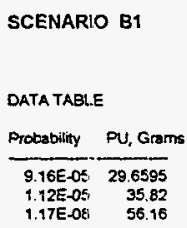

FIRE INDUCED PU RELEASE OUTSIDE BLDG Annual Probability, eventsiyear

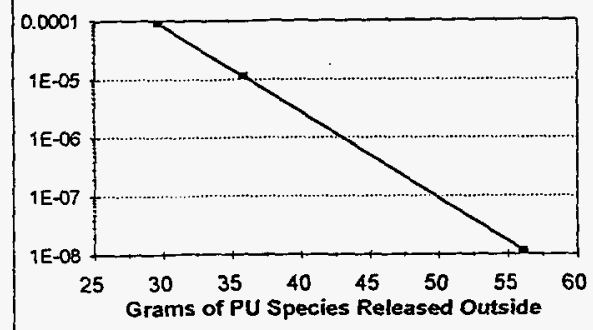


WHC-SD-WM-FHA-008, Rev. 0 page 90

RISK PROFUE B2

Representative Moderate Size CWC Buildings, 2403WA. WB, WC

Scenario B2 - Fire with Mechanical Ventilation ON

MCFL

Maximuin Credible Fire Loss

\begin{tabular}{|c|c|c|}
\hline Sprinkder Actiration Time & 24.8 & Minutes \\
\hline $\begin{array}{c}\text { Smoke layer 'Temp. } 9 \\
24.8 \text { minutes }\end{array}$ & 132 & $\boldsymbol{F}$ \\
\hline $\begin{array}{l}\text { Averege Reluase Rate of PU } \\
\text { Species outside the Building } \\
\text { over } 0-25 \text { minule time inlerval. }\end{array}$ & \multicolumn{2}{|c|}{ 4.3E-05 kg/s } \\
\hline $\begin{array}{l}\text { Aocumulative release of PU } Q \\
24.8 \text { minutes } \\
\text { Ortside the Eutiling }\end{array}$ & \multicolumn{2}{|c|}{63.865 Grams PU } \\
\hline $\begin{array}{l}\text { Annualized Probability } \\
\text { of MCFL Event }\end{array}$ & \multicolumn{2}{|c|}{ 9.2E-OS eventsyeaf } \\
\hline $\begin{array}{l}\text { MCF scenaiio assumes sprink } \\
\text { Sprinkter activation time was est }\end{array}$ & $\begin{array}{l}\text { ler system } \\
\text { imated us }\end{array}$ & $\begin{array}{l}\text { s operate. } \\
\text { ing fPETo }\end{array}$ \\
\hline
\end{tabular}

MFL

Maximum Foreseeable Loss

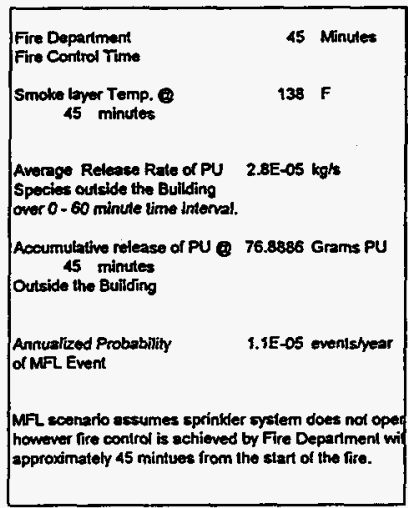

MPFL

Maximum Possible Fire Loss

Fire Duration Limit
$\begin{aligned} & \text { Smoke layer Temp. } \\ & 180 \text { minutes }\end{aligned}$
$\begin{aligned} & \text { Avernge Release Rate of PU } \\ & \text { Species outside the Building } \\ & \text { over } 0-180 \text { minute time interval. }\end{aligned}$

Accumulative release of PU $9 \quad 114$ Grams PU

180 minules

Outside the Building

Annualized Probability

of MPFL Event

$1.2 E-08$ eventshyear

MPF assumes sprinkler systems do not operale and

Fire Department does nol respond.

\section{SCENARIO B2}

DATA TABLE

\begin{tabular}{cr} 
Probability & PU, Grams \\
\hline $\begin{array}{r}9.16 E-05 \\
1.12 E-05\end{array}$ & $\begin{array}{r}63.865 \\
76.8886 \\
1.17 E-08\end{array}$ \\
114
\end{tabular}

FIRE INDUCED PU RELEASE OUTSIDE BLDG Annual Probability, events'year

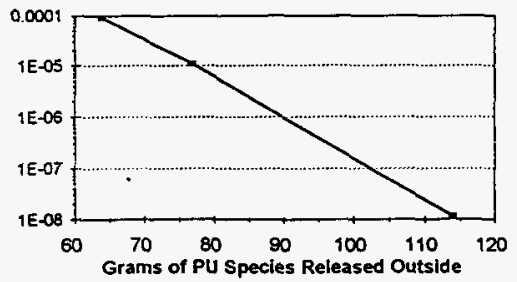




\section{RISK PROFILE C1}

Represents Large CWC Building, 2403 WD

Scenario C1 - Fire with Mechanical Ventilation OFF

MCFL

Maximum Credible Fire Loss

\begin{tabular}{|c|c|c|}
\hline Sprinker Activation Time : & 17.37 & Minutes \\
\hline $\begin{array}{c}\text { Smoke layer Temp. Q } \\
1737 \text { minules }\end{array}$ & 166 & $\boldsymbol{F}$ \\
\hline $\begin{array}{l}\text { Average Release Rete of PU } \\
\text { Species eartivide the Building } \\
\text { over } 0 \text { - } 18 \text { minule time inderva!. }\end{array}$ & \multicolumn{2}{|c|}{$1.7 E-05 \mathrm{~kg} / \mathrm{s}$} \\
\hline $\begin{array}{l}\text { Accumulative release or PU of } \\
17.37 \text { minutes } \\
\text { Outside the Bulding }\end{array}$ & \multicolumn{2}{|c|}{17.7753 Grams PU } \\
\hline $\begin{array}{l}\text { Annualized Probability } \\
\text { of MCFL Event }\end{array}$ & \multicolumn{2}{|c|}{ 9.2E-05 eventshear } \\
\hline $\begin{array}{l}\text { MCFL scenario assumes sprink } \\
\text { Sprinker activation time was est }\end{array}$ & $\begin{array}{l}\text { der system } \\
\text { timaled us }\end{array}$ & $\begin{array}{l}\text { is operate. } \\
\text { ing FPET } \alpha\end{array}$ \\
\hline
\end{tabular}

MFL

Maximum Foreseeable Loss

\begin{tabular}{|c|c|c|}
\hline $\begin{array}{l}\text { Fire Department } \\
\text { Firs Control Time }\end{array}$ & 38 & Minuter \\
\hline $\begin{array}{c}\text { Sinoke layer Temp. } \\
38 \text { minules }\end{array}$ & 257 & $F$ \\
\hline 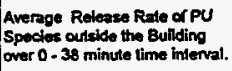 & $9.5 E-\infty 6$ & hots \\
\hline $\begin{array}{l}\text { Accurmutaltwe relase of PU } 18 \\
38 \text { minutes } \\
\text { Outside the Building }\end{array}$ & 21.72 & Grams PU \\
\hline $\begin{array}{l}\text { Annualized Probabifity } \\
\text { of MFL Even: }\end{array}$ & \multicolumn{2}{|c|}{ 1.1E-05 eventeryear } \\
\hline $\begin{array}{l}\text { MFL, scenario assumes sprinkde } \\
\text { however fire cortrol is actievod } \\
\text { approximalely } 38 \text { mintues from }\end{array}$ & $\begin{array}{l}\text { Is sysiom } \\
\text { by Fire D } \\
\text { the start o }\end{array}$ & $\begin{array}{l}\text { Loes nol oper } \\
\text { spertment wit } \\
\text { the fire. }\end{array}$ \\
\hline
\end{tabular}

MPFL

Maximum Possible Fire Loss

\begin{tabular}{|c|c|c|}
\hline Fire Duration Limă & 180 & Minutes \\
\hline $\begin{array}{l}\text { Smoke loyor Ternp. } 8 \\
180 \text { minutes }\end{array}$ & 76 & $F$ \\
\hline $\begin{array}{l}\text { Averege Releate Role of PU } \\
\text { Species outside the Building } \\
\text { over } 0 \text { - } 180 \text { minula time imional. }\end{array}$ & \multicolumn{2}{|c|}{$3.2 E-06 \mathrm{~kg} / \mathrm{s}$} \\
\hline $\begin{array}{l}\text { Acoumutative releeses of PU } \\
180 \text { minutes } \\
\text { Outside the Building }\end{array}$ & \multicolumn{2}{|c|}{$34.74 \mathrm{Grms} P U$} \\
\hline $\begin{array}{l}\text { Anmualized Probability } \\
\text { of MPFL Event }\end{array}$ & \multicolumn{2}{|c|}{ 1.2E-08 eventelyear } \\
\hline $\begin{array}{l}\text { MPFL essumes sprinkler systema } \\
\text { Fire Department does not respon }\end{array}$ & c do nol o & perato and \\
\hline
\end{tabular}

\begin{tabular}{|c|c|}
\hline \multicolumn{2}{|c|}{ SCENARIO CI } \\
\hline DATA TAEL & \\
\hline Probability & PU, Grams \\
\hline $\begin{array}{l}\text { 9.16E-OS } \\
\text { t.12E-05 } \\
1.17 E-08\end{array}$ & $\begin{array}{r}17.7753 \\
21.72 \\
34.74\end{array}$ \\
\hline
\end{tabular}

FIRE INDUCED PU RELEASE OUTSIDE BLDG Annual Probability, events/year

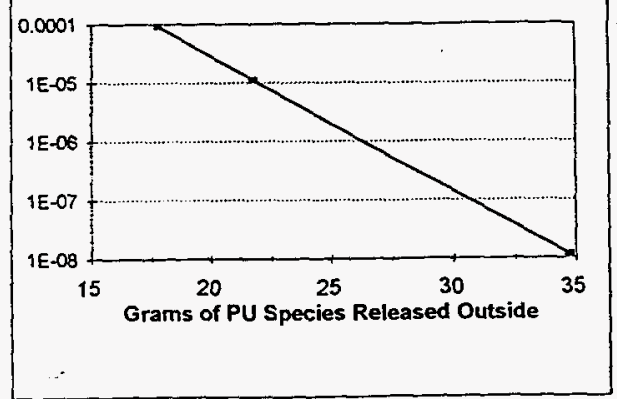


WHC-SD-WM-FHA-008, Rev. 0 page 92

\title{
RISK PROFILE C2
}

\author{
Represents Large CWC Building, 2403 WD
}

Scenario 02 - Fire with Mechanical Ventilation ON

MCFL

Maximum Credible Fire Loss

\begin{tabular}{|c|c|c|}
\hline Sprinker Activation Tine & 23.5 & Minules \\
\hline $\begin{array}{c}\text { Smoke layer Temp. } \\
23.5 \text { ininutes }\end{array}$ & 133 & $\boldsymbol{F}$ \\
\hline $\begin{array}{l}\text { Average Relerase Rate of PU } \\
\text { Species outalds the Building } \\
\text { over } 0.24 \text { minute time interval. }\end{array}$ & \multicolumn{2}{|c|}{ 4.4E.05 kg/s } \\
\hline $\begin{array}{l}\text { Accumulative release of PU } \mathrm{B} \\
23.5 \text { minutes } \\
\text { Outside the Euilding }\end{array}$ & \multicolumn{2}{|c|}{62.51 Grams PU } \\
\hline $\begin{array}{l}\text { Annualized Probability } \\
\text { of MCFL Event }\end{array}$ & \multicolumn{2}{|c|}{ 9.2E-05 events/rear } \\
\hline $\begin{array}{l}\text { MCF, scenalio assumes sprink } \\
\text { Sprinker activation time was est }\end{array}$ & $\begin{array}{l}\text { der system } \\
\text { olimated us }\end{array}$ & $\begin{array}{l}\text { is operate. } \\
\text { sing FPETo }\end{array}$ \\
\hline
\end{tabular}

MFL

Maximum foreseeable Loss

\begin{tabular}{|c|c|c|}
\hline $\begin{array}{l}\text { Fire Department } \\
\text { Fire Comtrol Time }\end{array}$ & & Minutes \\
\hline $\begin{array}{c}\text { Smoke layer Temp. } \\
44 \text { minutes }\end{array}$ & 168 & $F$ \\
\hline $\begin{array}{l}\text { Average Release Rale of PU } \\
\text { Spocies oulsido the Building } \\
\text { over 0-44 minute time intonal. }\end{array}$ & $2.9 E-05$ & $\mathrm{~kg} / \mathrm{s}$ \\
\hline $\begin{array}{l}\text { Accumulative release of PU } 8 \\
44 \text { minules } \\
\text { Octside the Buldding }\end{array}$ & 76.3758 & Gams PU \\
\hline $\begin{array}{l}\text { Annualized Probability } \\
\text { or MFl Evenl }\end{array}$ & \multicolumn{2}{|c|}{ 1.1E-05 eventsyear } \\
\hline $\begin{array}{l}\text { MFL scenario assumes sprinkte } \\
\text { however fire control is achieved } \\
\text { approximalely } 44 \text { mintues from }\end{array}$ & $\begin{array}{l}\text { er sysiem } \\
\text { iby Fire D } \\
\text { the slart of }\end{array}$ & $\begin{array}{l}\text { does not ope } \\
\text { Department wi } \\
\text { of the fire. }\end{array}$ \\
\hline
\end{tabular}

MPFL

Maximum Possible Fire Lo'ss

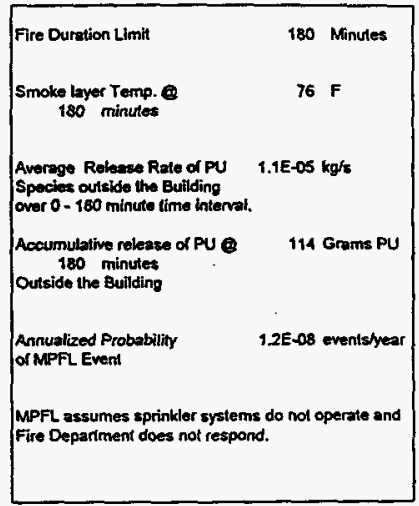

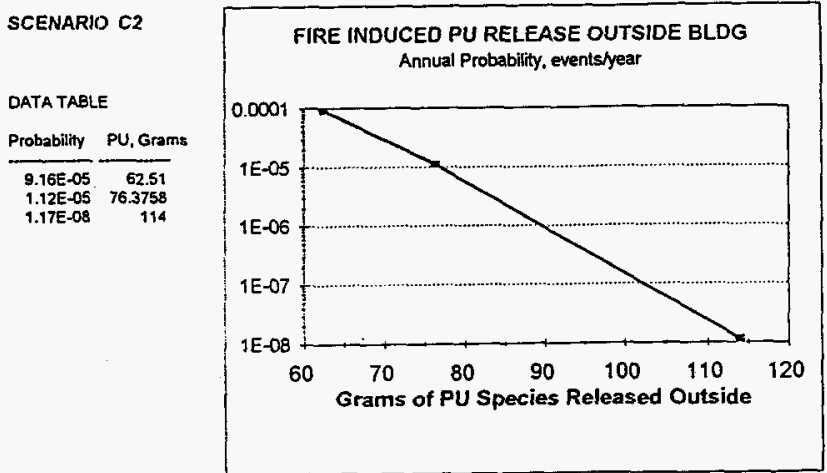


WHC-SD-WM-FHA-008, Rev. 0 page 93

RISK PROFILE D

Represents LFMW Storage Module 20 or 21

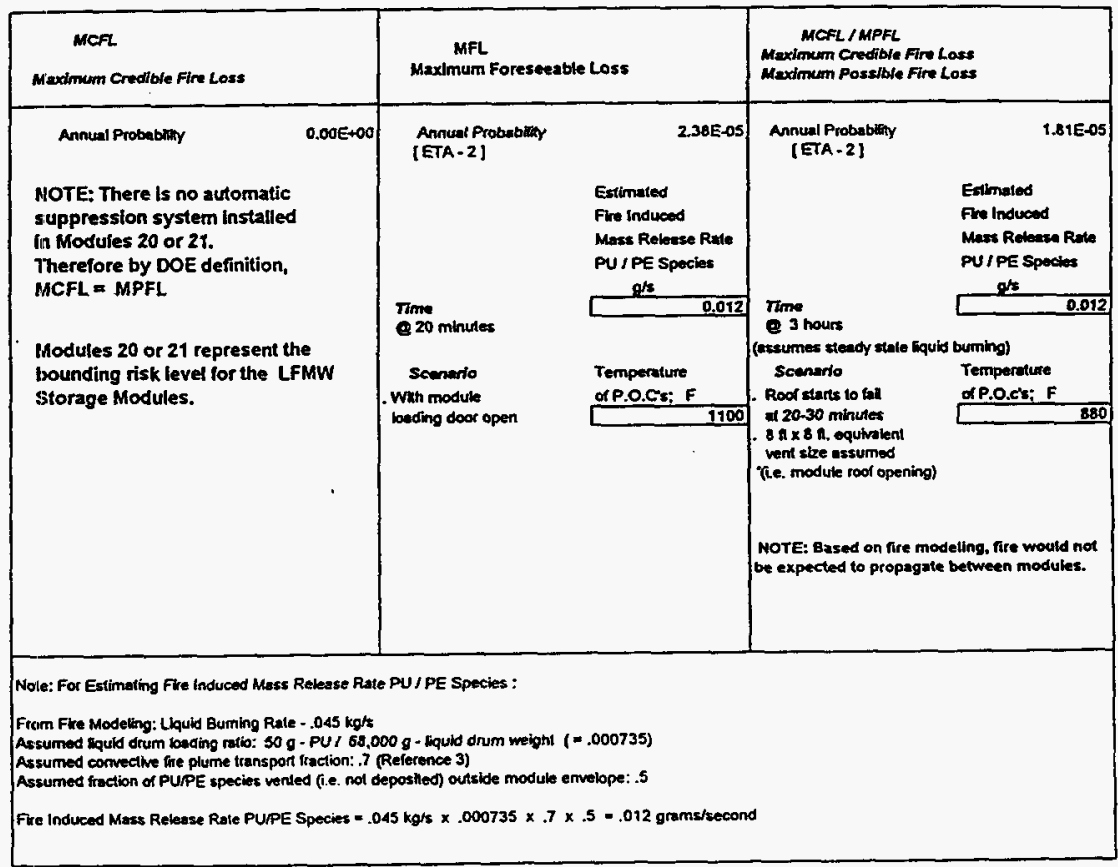


WHC-SD-WM-FHA-008, Rev. 0 page 94

RISK PROFWE E

\section{Represents CWC Storage Pad}

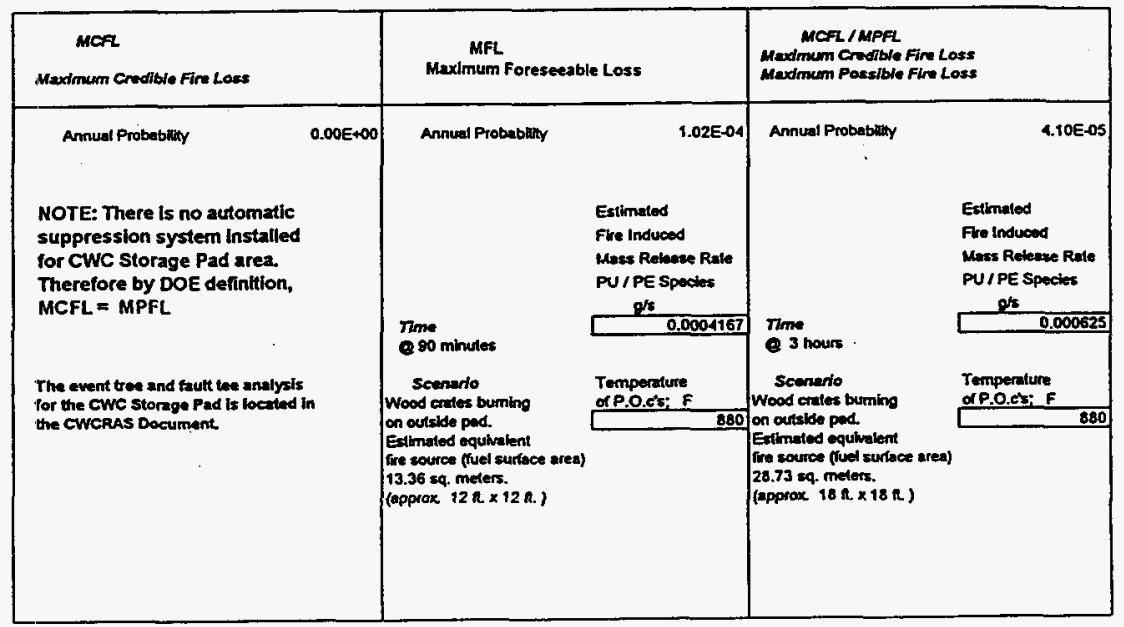


WHC-SD-WM-FHA-008, Rev. 0 page 95

\subsection{REFERENCES}

1. Solld Waste Drum Amag Fine Performance, WHC-SD-WM-TRP 246, Rev. O, issued 11/9S.

2. Deal, Scot, Technical Refenence Guide for FPErool Version 3.2, National Institute of Standards and Technology report NISTIR 5486, August 1994.

3. A Review of Aibom Release Frections For Contaminated Waste In Large Scale Liquid Pool Fires, Final Report, May 1995, by J.G. Quntiere, University of Maryland and G.D. Kaiser, SAIC, Report for U.S. Department of Energy, Rocky Flats Environmental Technology Site. 


\section{APPENDIX C \\ ESTIMATION OF EXTERNAL GROUND CONTAMINATION FROM MAXIMUM FORESEEABLE FIRE SCENARIOS}

Estimation of Ground Contamination Resulting from maximum foreseeable fire in Central Waste Complax Buildings is provided using the fire scenarios developed in this FHA, and the ground contamination modelling methodology developed in WHC-SD-GN-TI-20004, "A Method for Estimating Ground Areas Contaminated by a Postulated Fire in a Facility Containing Radioactive Material" [WHC, 1995a].

Determine Inventory at Risk (I) in curies.

Pages 87-94 lists the total accumulative release of Pu (in grams) for each scenario. Using an estimated platonium equivalent curies (PECi) value of 0.175 PECi/g (WHC-SD-WM-FHA015 ), inventory at risk can be calculated as shown in Table C-1.

$$
\begin{aligned}
\mathrm{I} & =(\text { quantity released }[\mathrm{g}]) \times(\mathrm{PECi} / \mathrm{g}) \\
& =69.4 \mathrm{~g} \times 0.175 \mathrm{PECi} / \mathrm{g} \\
& =12.1 \mathrm{PECi}
\end{aligned}
$$

Sample calculations are shown for the first scenario. 
Table C-1. Inventory at Risk.

\begin{tabular}{||l|l|l|l||}
\hline Scenario & Scenario Description & $\begin{array}{l}\text { Accumulative } \\
\text { Release [g] }\end{array}$ & $\begin{array}{l}\text { Inventory at } \\
\text { Risk, I [Ci] }\end{array}$ \\
\hline \hline A1 & $\begin{array}{l}\text { Fire in 2401 or 2402 bldg. } \\
\text { Ventilation OFF. }\end{array}$ & 69.4 & 12.1 \\
\hline A2 & $\begin{array}{l}\text { Fire in 2401 or 2402 bldg. } \\
\text { Ventilation ON. }\end{array}$ & 104 & 18.2 \\
\hline B1 & $\begin{array}{l}\text { Fire in 2403 WA, WB, or } \\
\text { WC bldg. Ventilation OFF. }\end{array}$ & 35.8 & 6.27 \\
\hline B2 & $\begin{array}{l}\text { Fire in 2403 WA, WB, or } \\
\text { WC bldg. Ventilation ON. }\end{array}$ & 79.9 & 14.0 \\
\hline C1 & $\begin{array}{l}\text { Fire in 2403 WD bldg. } \\
\text { Ventiktion OFF. }\end{array}$ & 21.7 & 3.80 \\
\hline C2 & $\begin{array}{l}\text { Fire in 2403 WD bldg. } \\
\text { Ventilation ON. }\end{array}$ & 76.4 & 13.4 \\
\hline
\end{tabular}

Determine Minimum Contamination Limit, $\mathrm{C}$.

Using the values for accessible soil concentration limits, 200-W area, as given in WHC-CM7-5, Table 6-2. This limit is given as $1.9 \mathrm{E}+02 \mathrm{pCi} / \mathrm{g}$ for Pu239 and Pu240.

$\mathrm{C}=(190 \mathrm{pCi} / \mathrm{g}) \times\left(1.6 \mathrm{~g} / \mathrm{cm}^{3}\right) \times\left(10^{-12} \mathrm{Ci} / \mathrm{pCi}\right) \times\left(10^{4} \mathrm{~cm}^{2} / \mathrm{m}^{2}\right)$

for a soil depth of $1 \mathrm{~cm}$

$=3.04 \times 10^{-6} \mathrm{Ci} / \mathrm{m}^{2}$ 
Determine Contamination Area (using the methodology of WHC, 1995a).

Method Assumptions:

- Estimation of releases as a function of particle fall velocity,

- Estimation of equilibrium plume height, using an established plume model,

- Meteorological conditions are Pasquill F stability with a reference $(10 \mathrm{~m})$ wind speed of $1 \mathrm{~m} / \mathrm{s}$.

- Fire's heat release rate $=Q^{\prime} / \mathrm{A}=397 \mathrm{~kW} / \mathrm{m}^{2}\left(9.48 \times 10^{4} \mathrm{cal} / \mathrm{m}^{2} \mathrm{~s}\right)$.

Problem Assumptions:

- Area of the fire, $A_{F}$, is equal to the area of four pallet stacks which may be involved in the fire. - Based on information from the full array palletized drum burn tests [WHC, 1995b], this is the maximum extent of drums that could be involved in the first 30 to 45 minutes before.the fire department has brought the fire under control.

- Minimum level of contamination, $\mathrm{C}$, is determined form accessible soil concentration limits identified above. Concentrations above this limit require cleanup. Concentrations below this limit do not.

From WHC, 1995a, the equation for determining the downwind extent of the contour corresponding to a minimum contamination level, $\mathrm{C}$, is:

$x_{I}=\left[64.9 \times(I / C) \times A_{F}^{0.8407}\right]^{(-1 / m)}$ (Equation C-1)

where:

$\mathrm{x}_{\mathrm{L}}=$ maximum downwind extent $(\mathrm{m})$

$\mathrm{I}$ = inventory at risk (Ci)

$\mathrm{C}=$ minimum contamination level $\left(\mathrm{Ci} / \mathrm{m}^{2}\right)$ 


$$
\begin{aligned}
& A_{F}=\text { area of the fire, }\left(5.95 \mathrm{~m}^{2}\right) \\
& \text { m }=\text { unitless parameter determined by: } \\
& \text { m }=-\left(0.02940 \ln A_{F}+3.248\right)
\end{aligned}
$$

(Equation C-2)

Solving Equation $\mathrm{C}-2$ yields:

$$
\begin{aligned}
& m=-(0.02940 \ln (5.95)+3.248) \\
& m=-3.300
\end{aligned}
$$

Solving Equation $\mathrm{C}-1$ yields:

$$
\begin{aligned}
& x_{L}=\left[64.9 \times\left(12.1 \mathrm{Ci} /\left(3.04 \times 10^{-6} \mathrm{Ci} / \mathrm{m}^{2}\right)\right) \times\left(5.95 \mathrm{~m}^{2}\right)^{0.8407}\right]^{(-1 /-3.300)} \\
& x_{\mathrm{L}}=.558 \mathrm{~m}
\end{aligned}
$$

From WHC, 1995a, the equation for determining the area of the contour corresponding to a minimum contamination level, $\mathrm{C}$, is:

$$
\begin{aligned}
& A_{C}=0.0724 \times(-m)^{0.5} \times\left(x_{I}\right)^{1.903} \\
& A_{C}=0.0724 \times(3.300)^{0.5} \times(553)^{1.903} \\
& A_{C}=22,200 \mathrm{~m}^{2}
\end{aligned}
$$

Using the same unit cost value as that referenced in WHC, 1995a, a unit clean up cost of $\$ 5.49 / \mathrm{m}^{2}$ is assumed.

Ground contamination clean up costs are calculated from $A_{c}$ and the unit clean up cost. These are shown in Table C-2 for the six scenarios. 
Table C-2. Ground contamination clean up costs.

\begin{tabular}{|c|c|c|c|}
\hline Scenario & Scenario Description & $\begin{array}{l}\text { Contamination } \\
\text { Area, } \mathrm{A}_{\mathrm{C}}\left[\mathrm{m}^{2}\right]\end{array}$ & $\begin{array}{l}\text { Ground Clean } \\
\text { Up Costs }\end{array}$ \\
\hline $\mathrm{A} 1$ & $\begin{array}{l}\text { Fire in } 2401 \text { or } 2402 \text { bldg. } \\
\text { Ventilation OFF. }\end{array}$ & 22,200 & $\$ 121,600$ \\
\hline A2 & $\begin{array}{l}\text { Fire in } 2401 \text { or } 2402 \text { bldg. } \\
\text { Ventilation ON. }\end{array}$ & 28,000 & $\$ 153,900$ \\
\hline B1 & $\begin{array}{l}\text { Fire in } 2403 \text { WA, WB, or WC } \\
\text { bldg. Ventilation OFF. }\end{array}$ & 15,200 & $\$ 83,300$ \\
\hline B2 & $\begin{array}{l}\text { Fire in } 2403 \text { WA, WB, or WC } \\
\text { bldg. Ventilation ON. }\end{array}$ & 24,100 & $\$ 132,300$ \\
\hline $\mathrm{C} 1$ & $\begin{array}{l}\text { Fire in } 2403 \text { WD bldg. Venti- } \\
\text { lation OFF. }\end{array}$ & 11,400 & $\$ 62,400$ \\
\hline $\mathrm{C} 2$ & $\begin{array}{l}\text { Fire in } 2403 \text { WD bldg. Venti- } \\
\text { lation ON. }\end{array}$ & 23,500 & $\$ 129,000$ \\
\hline
\end{tabular}

\section{Comparison of Two Methodologies}

This section addresses internal consistency of this FHA by comparing key data between the heat release rate development of Appendix B, and the ground contamination modelling of this appendix.

A fire area of $5.95 \mathrm{~m}^{2}$ was used in the ground contamination modelling. This is based on the fire department controlling the fire at approximately 30 minutes (Scenario 1). From drum array performance data [WHC, 1995b] it is apparent that an initiating event which involved the first pallet in each of two rows, could not spread beyond a second pallet in each row within this time.

Based on fire heat release rate profile developed in Appendix B of this FHA, an average heat release rate for the first 30 minutes is $2000 \mathrm{~kW}$. The methodology in WHC, 1995a defines a "standard" heat rate as $9.48 \mathrm{E}+4 \mathrm{cal} / \mathrm{m}^{2} \mathrm{~s}\left(397 \mathrm{~kW} / \mathrm{m}^{2}\right)$ and states that "an 'effective' fire area $\left(\mathrm{m}^{2}\right)$ may be calculated by dividing the actual total heat output of the fire $(\mathrm{cal} / \mathrm{s})$ by the standard heat rate $\left(9.48 \mathrm{E}+4 \mathrm{cal} / \mathrm{m}^{2} \mathrm{~s}\right)$." 
If the average total heat output determined from Appendix B is divided by the standard heat rate, we get:

$$
A=2000 \mathrm{~kW} /\left(397 \mathrm{~kW} / \mathrm{m}^{2}\right)=5.06 \mathrm{~m}^{2}
$$

This is within $15 \%$ of the value assumed for fire area in the ground contamination modelling, and indicates that the two analyses are consistent.

\section{REFERENCES}

WHC-SD-GN-TI-20004, Rev. 0, "A Method for Estimating Ground Areas Contaminated by a Postulated Fire in a Facility Containing Radioactive Material," Westinghouse Hanford Company, Richland, WA, 1995a.

WHC-SD-WA4-TRP:216, Rev. 0, "Solid Waste Drum Array Fire Performance," Westingho-

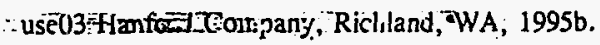




\section{APPENDIX D \\ SOLID WASTE MANAGEMENT (SWM) SUPPORTING INFORMATION AND IMPLEMENTATION OF CWC FHA}

\section{LOW FLASH POINT LOCKER DESIGN BASIS}

The current design basis for design and placement of LFPM is documented in WHC-SDWM-DB-031 which provides the regulatory guidance for the storage of low flash point material in outdoor storage lockers. This design basis document defines each LFPM as a "locker" with spacing requirements defined by NFPA-30 Table 4-6.4 of 5 feet between adjacent units with a maximum square footage of a group of lockers limited to 1,500 square feet. Per The CWC FHA and Risk Assessment Support Information, which defines the LFPM fire propagation analysis, the bounding postulated event occurs with a pool fire outside a module with the door open and flame impingement on the module across from the door opening. Based on the fire modeling propigation will not occur with a minimum spacing of 15 feet. Since the current and future module rows will be spacel at least 15 feet apart, the FHA continues to be consistent with the design basis document referenced above. Thus, propagation between modules is not expected. Furthermore, the scenarios analyzed in this FHA involve handling accidents with the potential for human intervention although no credit is taken for personnel mitigation. The normal unattended storage conditions will involve the waste container located in the module with the doors closed which will provide additional mitigation against propagation.

Six additional LFPM shall be added to the 19 current LFPMs. The design and construction shall comply with the assumptions and analysis contained in this document. Since the waste types will be identical to the current LFPMs, these modules shall be bounded by this analysis. Thus, the total number of operational LFPMs shall be 25 once the construction and readiness activities are completed for these additional 6 LFPMs. 


\section{SWM RECOMMENDATION RESOLUTIONS}

95-1 Provide manual exterior exhaust fan shutdown switches for Buildings 2403-WA, WB, WC, and WD to provide a means for the fire department to manually control the exhaust fans (UFC).

SWM Corrective Actions: Electrical supply to each of the 2403 series buildings is controlled by individual service disconnect switches located on the southeast corner of 2403-WA on the electrical service pad. The CWC building emergency plan identifies the possible options for HVAC disconnects for the CWC facilities and recognizes that they may be secured internally or externally for all CWC buildings. Thus, the service disconnects for each 2403 series building satisfies the requirement for exterior fan shutdown switches and no further facility action is required. The CWC Prefire plan maintained by the Hanford Fire Department shall be updated to incorporate this information. A Waste Remediation Tracking System item will be initiated to track and document completion of this activity.

95-2 Provide additional permanently installed heater capacity or improve valve house insulation so that portable heaters are not needed in sprinkler valve houses (NFPA 13).

SWM Corrective Actions: SWM Facility Engineering has evaluated permanently installed heater capacity for all CWC facilities and has identified the potential for inadequate heater capacity in the 2403 series buildings due to the external exposure of the riser rooms and undersized permanent heater capacity. A Waste Remediation Action Tracking System item will be initiated to track and document additional heater capacity to be added to the 2403 series buildings so that portable heaters are not needed. It is important to note that SWM shail continue to stage portable heaters in CWC riser rooms as a contingency for permanent heater failure. SWM has deemed that the practice of staging portable heaters is a prudent measure to add additional protection for CWC riser rooms. 
95-3 Review the capacity of the dry pipe sprinkler piping served by each auxiliary drain to determine if the pipe capacity is greater than $18.9 \mathrm{~L}(5 \mathrm{gal})$. If the capacity of the piping served by an auxiliary drain is greater than $18.9 \mathrm{~L} \mathrm{(5} \mathrm{gal),} \mathrm{two}$ 2.5-cm (1-in) valves and one $5.1-\mathrm{cm}$ by $30.5-\mathrm{cm}$ ( 2 -in. by 12 -in.) condensate nipple or equivalent need to be provided for the auxiliary drain to comply with NFPA 13 requirements.

SWM Corrective Actions: The Central Waste Complex dry pipe sprinkler systems do not have any auxiliary drains beside the inspector's test valve (ITV) which only drains a 12 foot section of piping located at the most remote point for the system. The CWC fire systems meet the "time to water" requirements with the current design. Since all piping drains back to the riser room, no additional auxiliary drains are required. Therefore, recommendation 95-3 does not apply to the current configuration of CWC.

95-4 Alter sprinkler systems or water supply if minimum density for Ordinary Hazard, Group 1 and a 1,892 $\mathrm{lpm}$ (500 gpm) hose stream allowance is to be achieved for Buildings $2401-\mathrm{W}$ and $2402-\mathrm{W}$ through WL, as required by DOE $6430.1 \mathrm{~A}$.

SWM Corrective Actions: Conclusions for the 2402 series buildings provided on page 13 state that these fire systems are capable of providing acceptable density and hose demand for a 1,950 square foot area. In the fire analysis of Appendix $B$ it is concluded that the fire would not be expected to propagate beyond 2 storage piles (rows) over a 3 hour timeframe. Each of the 2402 series buildings are capable of nominally storing 6 rows of containers so only one third of the building would be affected during the bounding fire. Since the total square footage of the buildings is 4,000 , one third would equal approximately 1,350 square feet which is well below the design capacity calculations specified for the fire systems. Thus, the fire system densities and hose demand for the 2402 series buildings are acceptable as configured. 


\section{SWM BASIS FOR LABPACK WASTE FORMS}

This section addresses the current basis for SWM definition of liquid waste packaged in labpack form. Professional Loss Control (PLC) addressed this situation in the comment resolution by stating that "since the liquids stored within the building are packaged in twice the absorbent need to contain the liquid, the liquid was treated as a highly toxic solid waste". This is consistent with the SWM waste definition of solid waste. If additional evaluation of this topic is deemed necessary in the future it will be addressed in the periodic fire protection assessment for CWC.

\section{REFERENCES}

WHC-SD-WM-DRD-005, Rev. 0, Functional Design Requirements for Low Flash Point Lockers, Jan. 1996.

WHC-SD-WM-DB-031, Rev. 0, Basis for Functional Design Requirements for Low Flash Point Lockers, Jan. 1996.

\section{ENDNOTES}

1. Duraspeed is a trademark of ITT Grinnell, Exeter NH.

2. Pyrotronics is a trademark of Cerebrus Space, Mannedorf Switzerland.

3. Compaq is a trademark of Compaq Computer Corporation, Houston Tx. 